UNIVERSIDADE DE SÃO PAULO

FACULDADE DE SAÚDE PUBLICA

\title{
A PRIVATIZAÇÃO DA ATENÇÃO PRIMÁRIA À SAÚDE DO MUNICÍPIO DE SÃO PAULO NO CONTEXTO DO CAPITALISMO FINANCEIRIZADO: UMA DISCUSSÃO CRÍTICA
}

Felipe Gonçalves Corneau

Dissertação apresentada ao Programa de PósGraduação em Saúde Pública para obtenção do título de Mestre em Ciências

Área de Concentração: Saúde Pública

Orientação: Prof. Dr Áquilas Nogueira Mendes

São Paulo

2016 


\section{A privatização da Atenção Primária à Saúde do município de São Paulo no contexto do Capitalismo Financeirizado: \\ Uma discussão crítica}

\section{Felipe Gonçalves Corneau}

Dissertação apresentada ao Programa de Pós-Graduação em Saúde Pública para obtenção do título de Mestre em Ciências

Área de Concentração: Saúde Pública

Orientação: Prof. Dr Áquilas Nogueira Mendes

São Paulo

2016 
Corneau, Felipe Gonçalves

A privatização da Atenção Primária à Saúde do município de São Paulo no contexto do Capitalismo Financeirizado: Uma discussão crítica / Felipe Gonçalves Corneau; orientador Áquilas Nogueira Mendes. - São Paulo, 2016.

$143 \mathrm{p}$.

Dissertação (Mestrado) - Faculdade de Saúde Pública da Universidade de São Paulo, 2016.

1. capitalismo em crise e a dominância do capital portador de juros. 2. a assistência à saúde e a dinâmica da luta de classes numa perspectiva histórica - breve retrospectiva do século XX. 3. as organizações sociais na APS do município de São Paulo: notas críticas 


\section{AGRADECIMENTOS}

Agradeço a todos que estiveram comigo nessa jornada.

Agradeço aos amigos e familiares pela compreensão nos muitos momentos em que não pude estar presente, e também pelas conversas, pela alegria e pelo apoio nos muitos outros em que estivemos juntos. Carol, Gustavo, meu pai Roberto, Inês, Ariclenis, Gerson, Denize, Mariana, Vitor, Demian, Antônio, muito obrigado.

Aos colegas de trabalho, pela torcida, pela ajuda e pelo companheirismo. Dedicadamente, são vocês que constroem esse SUS - muitas vezes à base de sangue, suor e lágrimas. Vocês são o motivo e a inspiração para esse estudo e tem toda a minha admiração. Muito obrigado às equipes das UBSs Almirante Delamare, Orquídeas e Alvarenga. Um agradecimento especial às colegas Vandrea e Natália.

Aos colegas da Faculdade de Saúde Pública pelo aprendizado e pelas discussões. Paula, Ricardo, Gaúcho, Thiago Marques, Aurea, Cristina, Marilia e muitos outros: foram vocês que tornaram esse processo tão rico.

Aos companheiros na luta por uma sociedade mais justa, obrigado pelas lições e pela compreensão. Paulo, Heitor, Alexandre, Lívia, Sérgio, Adriano e incontáveis outros, muito obrigado. Obrigado também ao xará, pela inspiração, pela disposição e pelo companheirismo.

Á minha mãe, Santina, que é, não só exemplo de força e coragem, como também foi quem permitiu que tudo isso se iniciasse. A todo o momento, dependi do seu esforço e abnegação. Muitíssimo obrigado.

Ao meu orientador Áquilas. A ele agradeço não somente pelos muitos textos a que me apresentou, pelas muitas discussões, aulas e lições. Agradeço principalmente pelo grande exemplo de empenho e dedicação. Obrigado pelo companheirismo e compreensão, professor.

À Bruna, que esteve comigo em cada passo, na discussão de cada ideia, na leitura e crítica de cada rascunho. A você que é companheira de luta, do SUS, de estudos, de lazer e, principalmente, da vida. Obrigado pela incrível parceria e paciência, obrigado pelo amor e carinho. 


\section{RESUMO}

Desde o início da década de 1990, as reformas gerenciais têm sido apresentadas como fundamentais para melhorar os serviços públicos e viabilizar a consecução dos direitos sociais. A partir de revisão da bibliografia e da análise de documentos, o trabalho faz uma análise crítica da privatização da gestão dos serviços públicos de Atenção Primária à Saúde no município de São Paulo, contextualizando tais medidas tanto no cenário do capitalismo contemporâneo sob dominância financeira, como também da construção da assistência pública à saúde no Brasil no século XX. Após retomar aspectos conceituais e históricos relacionados ao capitalismo contemporâneo sob a supremacia do capital financeiro, o estudo retoma a construção da assistência pública à saúde no Brasil na sua relação com a acumulação capitalista, além de fazer breve retrospectiva da construção do processo de privatização da Atenção Primária a Saúde no município de São Paulo, com destaque para as Organizações Sociais. Ao discutir em que medida foram alcançadas as melhorias prometidas e também a maior participação da comunidade no planejamento e execução dos serviços públicos, o estudo levanta a hipótese de que tais reformas estariam menos relacionadas às tentativas de viabilizar o direito universal à saúde. Tais medidas estariam, na verdade, submetidas a uma ofensiva das classes proprietárias em sua tentativa de superar as crises de acumulação capitalista, assim como também à concomitante ascensão internacional da finança e sua insaciabilidade sobre os recursos do Estado em benefício da lógica mais geral do movimento do capital.

Palavras-chave: Sistema Único de Saúde; Privatização; Atenção Primária à Saúde; Gestão dos Serviços de Saúde; Capitalismo Financeirizado. 


\section{ABSTRACT}

Since the early 1990s, the managerial reforms have been presented as fundamental to the improvement of public services and to facilitate the achievement of social rights. From a review of the literature and the analysis of documents, the study perform a critical analysis of the privatization of the management of public services of primary health care in São Paulo, contextualizing such measures in both the scenario of contemporary capitalism under financial dominance as also the construction of public health care in Brazil in the twentieth century. After resuming conceptual and historical aspects related to contemporary capitalism underthe supremacy of financial capital, the study takes up the construction of public health care in Brazil in its relation to the capitalist accumulation, in addition to brief review of the process of privatization of Primary Health Care in São Paulo, with emphasis on Social Organizations. When discussing to what extent the promised improvements and also the greater community participation in the planning and execution of public services were achieved, the study hypothesizes that such reforms would be less related to the attempts to make possible the right to universal health care. Such measures would be, in fact, subjected to an offensive of the proprietary classes in their attempt to overcome the crisis of capitalist accumulation, as well as the concurrent international rise of finance and its insatiability of State resources in favor of the more general logic to the movement of capital.

Keywords: Unified Health System; Privatization; Primary Health Care; Health Services Administration; Financial Capitalism. 


\section{Sumário}

RESUMO

LISTA DE SIGLAS



1. O Capitalismo em crise e a dominância do capital portador de juros .... 17

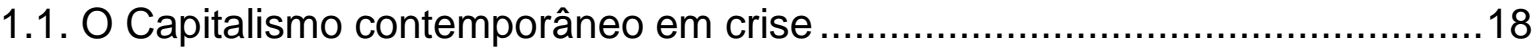

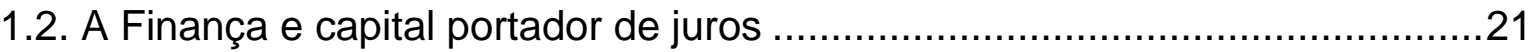

2. A assistência à saúde e a dinâmica da luta de classes numa perspectiva histórica - breve retrospectiva do século XX ....................................... 41

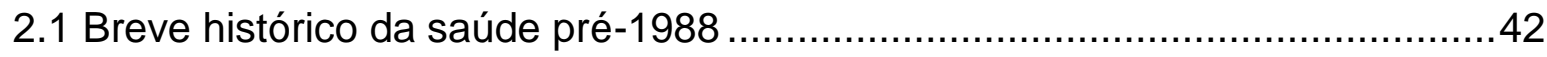



3. As Organizações Sociais na APS do município de São Paulo: notas



3.1 A Atenção Primária à Saúde no município de São Paulo ………………........80

3.2 O gerencialismo como paradigma para a gestão dos serviços de saúde .........96

3.3 A terceirização dos serviços públicos em São Paulo e o capital portador de juros

Considerações Finais 121

Referências Bibliográficas 


\section{LISTA DE SIGLAS}

Abramge Associação Brasileira de Medicina de Grupo

AD Administração Direta

AIS

Ações Integradas de Saúde

AMA Atendimento Médico Ambulatorial

AMB Associação Médica Brasileira

APS

Atenção Primária à Saúde

CAF

Comissão de Acompanhamento e Fiscalização

CAPs Caixas de Aposentadorias e Pensões

Cebes Centro Brasileiro de Estudos de Saúde

CF Constituição Federal

CIAM Centro de Integração de Atividades Médicas

CNS Conferência Nacional de Saúde

Cofins Contribuição para Financiamento da Seguridade Social

Conasems Conselho Nacional de Secretários Municipais de Saúde

CONASP Conselho Consultivo da Administração de Saúde Previdenciária

Conass Conselho Nacional de Secretários de Saúde

COOPERMED Cooperativa dos Profissionais de Nível Médio

COOPERPAS Cooperativa de Profissionais de Saúde

CPMF Contribuição Provisória sobre a Movimentação Financeira

CSLL $\quad$ Contribuição sobre o Lucro Líquido

CSSM Casa de Saúde Santa Marcelina

CUT Central Única dos Trabalhadores 


\begin{tabular}{ll} 
DNSP & Departamento Nacional de Saúde Pública \\
DRU & Desvinculação das Receitas da União \\
EC & Emenda Constitucional \\
EUA & Estados Unidos da América \\
FBH & Federação Brasileira de Hospitais \\
FHC & Fernando Henrique Cardoso \\
Fiocruz & Fundação Oswaldo Cruz \\
FIPE & Fundação Instituto de Pesquisas Econômicas \\
FMI & Fundo Monetário Internacional \\
FUNRURAL & Fundo de Assistência ao Trabalhador Rural \\
IAPs & Institutos de Aposentadorias e Pensões \\
Inamps & Instituto Nacional de Assistência Médica da Previdência Social \\
INPS & Instituto Nacional de Previdência Social \\
LOPS & Lei Orgânica da Previdência Social \\
LRF & Lei de Responsabilidade Fiscal \\
MES & Ministério da Educação e Saúde \\
MP & Medida Provisória \\
MPOG & Ministério do Planejamento Orçamento e Gestão \\
MST & Movimento Sem Terra \\
MTIC & Ministério do Trabalho, Indústria e Comércio \\
NHS & National Health Service \\
NTCS & Ne Contratação de Serviços de Saúde \\
\hline
\end{tabular}


OS

PACS Programa dos Agentes Comunitários de Saúde

PAS

PDRAE Plano Diretor da Reforma do Aparelho do Estado

PDT

PEC

PECs

Piass

PMS

PNAD

PND

PNS

Prev-Saúde

PRORURAL

PSDB

PSF

PT

Qualis

RSB

SAMU

SES

SESP

Organizações Sociais

Plano de Atendimento à Saúde

Partido Democrático Trabalhista

Proposta de Emenda Constitucional

Programas de Extensão de Cobertura Nordeste

Programa Metropolitano de Saúde

Pesquisa Nacional por Amostra de Domicílios

Plano Nacional de Desenvolvimento

Pesquisa Nacional de Saúde

Programa de Assistência ao Trabalhador Rural

Partido da Social Democracia Brasileira

Programa Saúde da Família

Partido dos Trabalhadores

Projeto Qualidade Integral em Saúde

Reforma Sanitária Brasileira

Serviço de Atendimento Móvel de Urgência

Secretaria Estadual de Saúde

Serviço Especial de Saúde Pública
Programa de Interiorização das Ações de Saúde e Saneamento do

Programa Nacional de Serviços Básicos de Saúde 
SMS

Secretaria Municipal de Saúde

SUDS

Sistema Unificado e Descentralizado de Saúde

SUS

Sistema Único de Saúde

UBS

Unidade Básica de Saúde

Unicef

Fundo das Nações Unidas para a Infância

Unisa

Universidade Santo Amaro

URSS

União das Repúblicas Socialistas Soviéticas

WS

Welfare State 


\section{INTRODUÇÃO}

Analisar a medicina ou a assistência à saúde na sua articulação com as forças políticas ou os movimentos da economia pode parecer despropositado para alguns. Afinal, não é a medicina profissão nobre e antiga, que resistiu à queda de Roma e Constantinopla, que remete a Hipócrates, Galeno e Paracelso? Sim, é certo que o cuidado à saúde ou a medicina não surgem na configuração econômica atual mesmo em tempos remotos, sociedades de coletores e caçadores contaram com pessoas especializadas no cuidado à saúde, aplicando para isso um conjunto de conhecimentos mais ou menos sofisticado. Apesar disso, mesmo a medicina não tem sido sempre a mesma; com o passar das eras, ela mudou, tomou outra forma. As mudanças mais relevantes datam dos últimos três séculos: já a partir do final do século XVIII, tivemos não somente novos recursos tecnológicos aplicados à investigação biomédica, mas principalmente uma mudança de método que transformou decisivamente a sua prática (FOUCAULT, 2011).

Mas não são tais mudanças técnicas ou metodológicas que justificam a análise da medicina ou da assistência à saúde na sua relação com os poderes políticos ou movimentos econômicos, mas sim a maneira pela qual a assistência à saúde passou a se articular com o todo da sociedade nesse período. Seja pelas funções políticas que passa a desempenhar ${ }^{1}$, ou pelas articulações que passa a desenvolver com a esfera econômica, o setor saúde passa a contar com um novo conjunto de influências. A importância de analisá-los na sua articulação com as demais "práticas sociais" é exposta por Donnangelo:

"A medicina, que em uma primeira aproximação pode ser encarada como prática técnica, isto é, como manipulação de um conjunto de instrumentos técnicos e científicos para produzir uma ação transformadora sobre determinados objetos - o corpo, o meio físico - responde, enquanto tal, a exigências que se definem à margem da própria técnica, no todo organizado das práticas sociais determinadas, econômicas, políticas e ideológicas entre as quais se inclui. Tais exigências regulam não apenas a presença da própria prática, mas participam também do dimensionamento

\footnotetext{
${ }^{1}$ Foucault argumenta em seu texto sobre a o nascimento da medicina social: "Minha hipótese é que com o capitalismo não se deu a passagem de uma medicina coletiva para uma medicina privada, mas justamente o contrário; que o capitalismo, desenvolvendo-se em fins do século XVIII e início do século XIX, socializou um primeiro objeto que foi o corpo enquanto força de produção, força de trabalho. O controle da sociedade sobre os indivíduos não se opera simplesmente pela consciência ou pela ideologia, mas começa no corpo, com o corpo. Foi no biológico, no somático, no corporal que, antes de tudo, investiu a sociedade capitalista. O corpo é uma realidade biopolítica. A medicina é uma estratégia biopolitica" (FOUCAULT, 2015, p. xx).
} 
do objeto ao qual se aplica, dos meios de trabalho que ela opera, da forma e destinação de seus produtos. Essa articulação da medicina com as demais práticas sociais constitui o ponto estratégico do qual melhor pode se apreender o seu caráter histórico." (DONNANGELO; PEREIRA, 1976, p. 15).

Ou seja, é somente na análise do trabalho em saúde em sua articulação com os outros aspectos da vida social que se pode entender melhor seus objetos, seus instrumentos, formas que adquire e suas articulações com outras esferas, como com a esfera do ideológico, do político e do econômico.

Para Navarro, por exemplo, a medicina cumpre importante papel ideológico na legitimação da sociedade capitalista. Ela ajuda a construir uma narrativa sobre as causas e soluções das doenças e sofrimentos. Fatores sociais, coletivos e ocupacionais são frequentemente subestimados, quando não ignorados, enquanto fatores individuais aparecem como os únicos dignos de análise e intervenção:

"A Medicina é de fato socialmente útil na medida em que a maioria das pessoas acredita e aceita a proposição de que, condições que tem na realidade causas políticas, podem ser resolvidas por intervenção médica. Do ponto de vista do sistema capitalista, esta é a real utilidade da medicina; contribui para a legitimação do capitalismo"2 (NAVARRO, 1976, p. 447 , tradução nossa).

O cuidado dos chamados "problemas de saúde mental" talvez seja o mais emblemático dessa distorção descrita por Navarro; nesse tipo de cuidado, frequentemente tentamos resolver complexas situações de sofrimento psíquico, muitas vezes intrincadamente relacionadas a situações de pobreza e vulnerabilidade social, com intervenções eminentemente individuais, como a orientação de "mudanças no estilo de vida" e a administração de uma medicação que aumenta a disponibilidade cerebral de certo neurotransmissor.

Para além da função política que tal intervenção ideológica já cumpre, vale a pena citar também a contribuição de autores como Foucault, que esclarecem o extensivo uso do discurso e da prática médica no controle dos corpos e na manutenção da ordem:

"Vê-se, claramente, a transposição, na legislação médica, do grande problema político da burguesia nesta época: a que preço, em que

2 Traduzido do original: "Medicine is indeed socially useful to the degree that the majority of people believe and accept the proposition that what are actually politically caused conditions can be solved by medical intervention. From the point of view of the capitalist system, this is the actual utility of medicine; it contributes to the legitimation of capitalism". 
condições e como assegurar sua segurança política. A legislação médica contida na Lei dos pobres corresponde a esse processo. Mas esta lei e a assistência-proteção, assistência-controle que ela implica, foi somente o primeiro elemento de um complexo sistema cujos outros elementos só aparecem mais tarde, em torno de 1870, com os grandes fundadores da medicina social inglesa, principalmente John Simon, que completaram a legislação médica da Lei dos pobres com a organização de um serviço autoritário, não de cuidados médicos, mas de controle médico da população." (FOUCAULT, 2015, p. 167)

Apesar das mais diversas maneiras pela qual o setor saúde influencia e é influenciado por questões "à margem da própria técnica", esse trabalho em específico não tem o objetivo de fazer tal análise em sua totalidade, o que resultaria, necessariamente, em um estudo bastante mais amplo e detalhado. Apesar de compreender a complexidade do tema, e reconhecer que os serviços de saúde são atravessados por questões políticas, ideológicas e econômicas das mais diversas, buscamos aqui realizar somente parte de uma discussão bastante específica, que é a maneira pela qual a dinâmica do capitalismo contemporâneo incide sob os modos de organizar a assistência pública à saúde no Brasil, em particular a Atenção Primária à Saúde (APS).

País retardatário na construção de direitos sociais, o Brasil garantiu a seus cidadãos o direito à saúde universal somente em 1988; em uma conjuntura bastante diferente daquela dos países da Europa Ocidental, por exemplo, que instituíram abrangentes sistemas de saúde universais no período do pós-Guerra. Desde a década de 1980, no entanto, mesmo esses países, que inspiraram a construção de um sistema de saúde universal em solo brasileiro, tem sofrido com reformas contencionistas e tentativas de desmonte (WAHL, 2011; FERREIRA, 2016). Nos anos 2010, a intensa discussão acerca da viabilidade de um Estado que garanta direitos trabalhistas e sociais toma contornos dramáticos, enquanto medidas de "desregulação" desses direitos são recebidas com acalorada luta política (YÁRNOZ, 2016).

Autores como Harvey (2013a; 2014), Duménil e Lévy (2005; 2010; 2014) e Chesnais $(2005 ; 2010)$ tem apontado que as políticas implementadas nesses países desde a década de 1980, chamadas de neoliberais, estão relacionadas a algumas mudanças ocorridas, tanto no âmbito econômico como político, desde a década de 1970. Com a ascensão, no interior do processo de acumulação capitalista, de um tipo específico de capital, o capital portador de juros, teria se estabelecido também a 
hegemonia das frações de classe e das instituições associadas à sua operação. A preponderância das políticas neoliberais observada nas últimas décadas, portanto, estaria intrinsecamente ligada à ascensão internacional da finança e sua insaciabilidade sobre os recursos do Estado em benefício da lógica mais geral do movimento do capital.

Esse trabalho busca discutir, no contexto brasileiro, a ascensão da finança e suas repercussões nas políticas de saúde, em geral e na atenção primária em saúde, em particular. Para adentrar e contribuir com esse debate, decidimos analisar o caso concreto da privatização da gestão da Atenção Primária a Saúde na cidade de São Paulo, com destaque para o papel das Organizações Sociais.

Cidade mais populosa do país, com mais de 11,9 milhões de habitantes em 2015 (IBGE, 2015), a sua análise já se justificaria por seu tamanho e importância. Mas além desses aspectos, consideramos relevante também o fato de que a cidade tem sido palco, nas últimas décadas, de algumas das maiores experiências de privatização da gestão dos serviços de saúde no Brasil. Desde o Plano de Atendimento à Saúde (PAS) de 1996 até as Organizações Sociais (OS) de 2016, são mais de 20 anos de experiências que envolvem a cessão dos equipamentos da rede pública de saúde - e também de seus trabalhadores - para a gestão de entidades privadas.

Os discursos oficiais por trás dessas experiências, assim como seus entusiastas, ressaltam repetidamente o efeito a ser obtido no aumento da eficiência dos serviços públicos (BRASIL, 1995; FIPE, 1995; IBAÑEZ et al., 2001; ORLANDO, 2012), e também a "democratização" e publicização do Estado que tais experiências proporcionariam (BRASIL, 1995; NASSUNO, 1999; INOJOSA, 2003).

O presente estudo pretende não somente discutir criticamente as evidências acumuladas acerca de um possível aumento de eficiência e de uma suposta "publicização" propiciados pelo modelo, mas discutir também essa experiência a partir de aspectos do capitalismo contemporâneo e da influência da reprodução capitalista na conformação da assistência pública à saúde no Brasil, desde o século XX. 
Para realizar tal discussão, foi realizada pesquisa bibliográfica e documental acerca de três temas principais, que se tornaram três capítulos. O primeiro trata da dinâmica do capitalismo contemporâneo em crise e sob dominância do capital portador de juros, assim como a ascensão da finança no contexto brasileiro. $O$ segundo retoma a evolução da assistência pública à saúde no Brasil e sua relação com a acumulação capitalista. O terceiro capítulo discute criticamente as experiências de privatização da gestão da assistência publica à saúde no município de São Paulo, com destaque para a análise da atuação das OS na gestão da Atenção Primária à Saúde. 


\section{O Capitalismo em crise e a dominância do capital portador de juros}

No ano de 2008, uma grande crise econômica de proporções globais atingia as economias de todo o mundo, tendo como epicentro o mercado imobiliário estadunidense. Para Zizek (2011), o fato mais surpreendente que se observaria a partir dali seria "a facilidade com que se aceitou a ideia de ter sido um fato imprevisível que, do nada, atingiu os mercados" (p. 21).

Depois das quedas das bolsas de ações do mundo todo e da falência de importantes bancos de investimento nos Estados Unidos da América (EUA), tanto o governo estadunidense como os principais governos europeus começaram a realizar empréstimos para salvar os bancos em valores que superavam as centenas de bilhões de dólares. Cinco anos após o momento mais grave da crise, a soma dos valores dispendidos para "salvar os bancos" já ultrapassava um trilhão de euros para cada um dos principais países europeus, como Alemanha, França, Itália, Espanha e Reino Unido (BANCO CENTRAL EUROPEU, 2015, p. 38). Nos EUA os valores podem ter sido ainda maiores (NEW YORK TIMES, 2011).

Políticos dos partidos mais variados, nos EUA e na Europa, uniram-se para apoiar os planos de resgate. Não seria possível para eles que aqueles bancos falissem, eram "too big to fail" (grandes demais para quebrar). Esses mesmos políticos retornariam somente alguns anos mais tarde apontando a necessidade de realizar cortes na saúde, na previdência, e também a necessidade de aumentar a jornada de trabalho (CNBC, 2016; THE GUARDIAN, 2016). Como apontou Zizek, há o perigo de que tamanha crise não sirva para revelar as assimetrias de poder e os gastos excessivos do Estado na remuneração do capital financeiro, mas sim para justificar assimetrias ainda mais severas. Em suas próprias palavras: "O perigo então é que a narrativa predominante da crise seja aquela em que, em vez de nos despertar de um sonho, nos permita continuar sonhando" (ZIZEK, 2011, p. 29).

De certa forma, temos situação semelhante no Brasil; ao mesmo tempo em que a remuneração dos bancos permanece intocada, direitos constitucionais como saúde e educação gratuitos são questionados (COMPARATO; TORRES; PINTO, 2016). Segundo dados da auditoria cidadã da dívida, o governo federal gastou, em 
2014, aproximadamente $45 \%$ do seu orçamento com o pagamento de juros e amortizações da dívida pública ${ }^{3}$. Os gastos em saúde desse orçamento teriam sido de apenas 3,98\%, para a educação, valores semelhantes, 3,73\% (CORNELLI, 2015).

A política de priorizar os pagamentos ao capital financeiro enquanto coloca em cheque a consecução de direitos básicos não é nada nova, tem sido a tônica dos governos federais desde, pelo menos, o início da década de 1990 (PAULANI, 2008). Não por coincidência, é na mesma época que surgem as propostas de "Reforma do Aparelho do Estado", dos quais fazem parte as OS.

Esse capítulo aborda alguns aspectos gerais do capitalismo contemporâneo em crise, sob a dominância do capital portador de juros. Busca-se assim, trazer elementos importantes para a compreensão das reformas gerenciais dos serviços de saúde no Brasil e, especificamente, em São Paulo.

O capítulo está estruturado em duas partes. A primeira parte aborda as características principais que evidenciam a crise do capitalismo contemporâneo. A segunda parte tem como objetivo apresentar alguns aspectos conceituais e históricos dessa nova fase do capitalismo contemporâneo financeirizado.

\subsection{O Capitalismo contemporâneo em crise}

Os últimos dois anos no Brasil tem sido de desaceleração do consumo, aumento do desemprego e retração da atividade econômica ${ }^{4}$. Depois de aproximadamente meia década de algum crescimento econômico, acompanhado até mesmo de certa euforia, o país parece estar de volta à era das crises. É certo que na crise econômica atual, uma das maiores da história, há uma boa quantidade de elementos conjunturais, como por exemplo, os escândalos de corrupção, as crises política e institucional e a queda no preço das chamadas "commodities". Apesar disso, não é somente desses elementos conjunturais que se compõe essa crise; ela está inserida, na verdade, numa crise estrutural do sistema capitalista.

\footnotetext{
3 Para mais ver: www.auditoriacidada.org.br.

4 Segundo o IBGE (2016), o crescimento do PIB brasileiro foi de 0,3\% em 2014. Em 2015, foi negativo, de $-3,8 \%$.
} 
Muitos analistas na grande mídia, e até mesmo na academia, põem a público a análise de que as características da atual crise econômica são consequência direta da política econômica dos governos dos últimos 15 anos. De certa forma, estão certos - mas talvez não da maneira como gostariam.

Como demonstra Harvey (2011), o segredo para entender a crise econômica de hoje está justamente na análise do modo pelo qual saímos da crise anterior. A verdade é que as medidas tomadas para o enfrentamento das crises econômicas anteriores no Brasil, em outros países, ou mesmo aquelas que têm sido tomadas de forma concertada, por vários desses países em conjunto, não lidam com as contradições fundamentais inerentes ao sistema capitalista; somente engendram saídas temporárias. Com as "soluções" que têm sido implementadas, os mesmos problemas deverão ser enfrentados novamente no futuro, somente numa escala maior.

Para Harvey (2006), essa tendência estrutural à crise pode ser entendida - no que diz respeito às contradições internas da reprodução do capital - enquanto uma crise crônica de sobreacumulação, decorrente da dificuldade que o capital enfrenta em encontrar novas oportunidades lucrativas para o reinvestimento, num novo ciclo, do capital excedente proveniente do ciclo anterior.

Essa dificuldade crônica de encontrar oportunidades suficientemente lucrativas para o reinvestimento do capital, que tem principalmente origem na tendência à queda da taxa de lucro ${ }^{5}$, tem se mostrado particularmente mais difícil de enfrentar desde a década de 1970 - motivo pelo qual temos experimentado desde então diversas crises conjunturais (HARVEY, 2011). Isso tem importância fundamental para explicar a configuração econômica que vem se desenhando desde então, assim como também algumas das disputas que tem se dado no âmbito político e da institucionalidade Estatal. Como não poderia ser diferente, tem grande importância também para entender o desenvolvimento do setor saúde.

A migração dos capitais para a esfera financeira que temos experimentado nas últimas décadas, com a multiplicação exponencial no volume de capital fictício,

\footnotetext{
${ }^{5}$ Esse diagnóstico sobre a crise econômica pode ser encontrado de forma mais bem desenvolvida em Harvey (2006), e também nos trabalho de autores como Andrew Kliman (2012; 2015), Michael Roberts $(2013 ; 2015)$ e Callinicos $(2010 ; 2014)$.
} 
foi uma maneira encontrada pelos capitalistas para tentar escapar das decepcionantemente baixas taxas de lucro da produção industrial (segundo Kliman (2012), no caso dos Estados Unidos, houve uma persistente queda da taxa de lucro no setor corporativo das empresas industriais e financeiras no período pós-ll Guerra: queda de $41,3 \%$, entre 1949 a $2001^{6}$ ).

Foi também devido à busca de melhores oportunidades de lucro que se deu o enorme crescimento do setor de serviços, como o de saúde.

Mas não somente isso. A própria atuação do Estado pode cumprir papel decisivo na superação, ao menos temporária, dessas crises. Embora tal "instrumentalização" do Estado no sentido de garantir a acumulação capitalista não seja exatamente uma novidade, longe disso, o Neoliberalismo ${ }^{7}$ tem se mostrado, nas últimas décadas, a principal maneira através da qual as classes proprietárias têm incidido política e ideologicamente.

São parte integrante dessa estratégia ao menos três processos centrais: (1) a diminuição dos custos com a remuneração do trabalho, conseguida principalmente através do ataque às organizações trabalhistas, da diminuição de salários, de demissões em massa e das deslocalizações ${ }^{8}$; (2) a liberação de novos loci para a reprodução do capital, como por exemplo através da privatização de áreas que até então estavam sob o controle do Estado, ao exemplo dos setores monopolistas (transportes, energia, etc.) e dos serviços de educação e saúde; (3) a liberalização dos fluxos financeiros e a garantia da remuneração do capital financeiro, sendo realizada inclusive diretamente pelo Estado, por meio do pagamento de juros sobre a dívida pública.

Para Harvey (2013a), a acumulação capitalista realizada através das privatizações ou através do pagamento da dívida pública é parte importante da dinâmica capitalista das últimas décadas. Para o autor, esses processos (e também muitos outros) são exemplos importantes de que as tentativas de fugir da tendência

\footnotetext{
6 Ver Kliman (2012), cap.5, Tabela 5.1, p.82.

7 Para Harvey (2014), o Neoliberalismo é a parte política e ideológica de uma ofensiva das classes proprietárias que tem o objetivo de reconquistar parte da dominância política e econômica perdidas no pós-guerra. Como demonstram Duménil e Lévy (2005; 2010), esse processo esteve também intimamente associado à ascensão da finança a partir da década de 1970. Para mais sobre o tema, ver Harvey (2014).

${ }^{8}$ Como por exemplo, as mudanças de grande grupos industriais dos países centrais para países periféricos, nos quais a força de trabalho é mais barata e menos organizada politicamente.
} 
imanente do capitalismo à crise nem sempre se limitam à esfera estritamente econômica; muitas vezes é necessário recorrer a métodos violentos. O autor chama essas e outras estratégias para escapar às limitações da reprodução ampliada do capital de "acumulação por espoliação" 9.

Dentre os três processos citados, todos eles têm relação importante com a privatização dos serviços públicos, sendo um dos principais protagonistas desse processo, o próprio capital financeiro. Aqui Harvey novamente exemplifica:

"a intervenção do capital financeiro respaldada pelo poder estatal frequentemente pode se tornar acumulação por outros meios. Uma aliança non sancta entre os poderes estatais e os aspectos predatórios do capital financeiro forma a ponta de lança de um "capitalismo de rapina" dedicado à apropriação e desvalorização de ativos, mais que à sua construção através de investimentos produtivos" (HARVEY, 2004, p. 107).

Entendendo, portanto, a privatização dos serviços públicos como parte de uma estratégia das classes proprietárias para lidar com sua crise de sobreacumulação e reconhecendo o protagonismo que o capital financeiro tem adquirido nesse processo, é importante buscarmos entender, ainda que superficialmente, alguns dos processos econômicos e políticos que figuram na atual dominância do capital portador de juros.

\subsection{A Finança e capital portador de juros}

As eleições presidenciais de 2014 no Brasil foram marcadas por uma grande polarização, principalmente no seu $2^{\circ}$ turno. Pelos debates públicos que se travavam e pelas declarações de ambos os candidatos, temas importantes pareciam estar sendo definidos ali. No que se refere aos direitos trabalhistas, a então candidata à reeleição foi enfática, chegando a dizer que no seu governo não os mudaria "nem que a vaca tussa" (EQUIPE DILMA ROUSSEF, 2014). No discurso da posse de seu segundo mandato, a presidenta Dilma Roussef manteve o tom: "Reafirmo meu profundo compromisso com a manutenção de todos os direitos trabalhistas e previdenciários" (ROUSSEF, 2015). Em relação à saúde, a plataforma do governo

\footnotetext{
9 Ao cunhar o conceito de "acumulação por espoliação", Harvey (2013a) faz referência ao fenômeno da "acumulação primitiva", descrito por Marx no capitulo 24 do livro I de O Capital (MARX, 2013). O autor argumenta que parte do processo descrito por Marx, em que a acumulação de capital se dá por meios explicitamente violentos, não se restringiu à "pré-história" do capitalismo, mas continua a ser processo bastante relevante ainda hoje.
} 
era vaga, mas reafirmava seu compromisso com o fortalecimento do SUS (MAGNO; PAIM, 2015).

Dois dias antes da posse, no entanto, a presidenta já havia assinado a Medida Provisória (MP) 665, que triplicava o tempo mínimo de trabalho necessário para se tornar elegível ao seguro desemprego pela primeira vez, restringindo, portanto, enormemente o seu acesso (BRASIL, 2014). Não muito depois, o governo pôs às claras também a sua postura em relação à saúde, com a lei 13.097, de 15 de janeiro de 2015, permitindo a entrada do capital estrangeiro na saúde; e a EC no 86/2015, do orçamento impositivo, que acabou diminuindo o orçamento para a Saúde em 2016, em relação a 2014. O que se seguiu nos meses seguintes somente confirmou essa tendência (MENDES, 2015).

Esse tipo de contradição, ainda que possa ser julgado por alguns como um problema moral ou como um desvio de caráter específico da presidenta, é deveras recorrente, não sendo exclusividade desse governo, partido, e nem mesmo uma peculiaridade brasileira. Tomando de empréstimo as palavras de Oliveira (2003, p.148), "aqui não se trata de condenação moral, mas de encontrar as razões para o que, para muitos, parece uma convergência de contrários despropositada". É importante que busquemos entender que tipos de forças aí atuam.

No caso específico do Brasil dos últimos 12 anos, ao julgar pela incongruência entre as promessas de campanha e as ações de governo, é possível observar que, embora as pressões como essas, (para a manutenção dos direitos trabalhistas ou para a ampliação dos direitos à saúde) tenham demonstrado sua preponderância nos momentos de eleições, assim que temos o governo eleito, pressões bastante diferentes parecem assumir o protagonismo. Em ambos os momentos, um ator que não merece nossa desatenção é o que muitas vezes se chama de "mercado".

Aqui nos referimos aos mercados financeiros de obrigações, títulos e ações das empresas. Esses mercados aparecem como protagonistas em uma miríade de análises políticas, seja nos noticiários da grande mídia ou nas análises acadêmicas, regendo a economia e influenciando as ações dos governos. As políticas macroeconômicas voltadas para satisfazê-los são propagandeadas como as únicas tecnicamente corretas e habilmente relacionadas com o respeito à coisa pública e ao 
governo responsável (PAULANI, 2008). Ao se tornarem "calmos" ou "agitados", sendo "agradados" ou "contrariados", os mercados assumem um misto de antropomorfização e impessoalidade. À moda das divindades míticas, se mostram poderosos, irascíveis e imperscrutáveis, enquanto suas demandas caprichosas tomam a forma de lei natural.

A verdade aqui é que, mesmo que suficientemente fetichizados, os mercados não podem ter, por si sós, qualquer preferência ou vontade. O que tratamos como "interesses dos mercados" é na verdade o vetor resultante dos interesses daquelas pessoas, grupos e instituições que atuam nesses mercados. Ainda que tal observação seja um tanto óbvia, nos previne de confundir os interesses desses atores específicos com um suposto interesse geral da sociedade, assim como também nos ajuda a evitar a naturalização das relações sociais que os sustentam ou de seus imperativos (resumida na famosa expressão "There Is No Alternative").

Essa antropomorfização, no entanto, não é completamente despropositada, pois são justamente os operadores das principais instituições financeiras que determinam características-chave desses mercados. Os principais atores desses mercados são reunidos por Duménil e Lévy no que definem simplesmente como "finança":

"A finança é um agente, ou se preferir, um ator, tanto econômico como político, em ação na história do capitalismo. É um objeto social que reúne dois elementos: (1) uma fração [superior] da classe capitalista, (2) um conjunto de instituições (os bancos e, incluídos no capitalismo moderno, o banco central e instituições não bancárias, nacionais ou internacionais como o Fundo Monetário Internacional, os fundos etc.)" (DUMÉNIL; LÉVY, 2010).

Essa seção busca, portanto, retomar de forma breve a natureza das relações econômicas que sustentam a finança, assim como algumas das características do capitalismo contemporâneo. Espera-se aproximar-se de um melhor entendimento tanto do estado atual das políticas e serviços públicos, como também da contraditória dissonância entre o debate público e as medidas adotadas pelos governos.

Ao esclarecer alguns aspectos conceituais acerca do caráter, da natureza e das relações que a finança estabelece no capitalismo contemporâneo, utilizaremos a obra de Marx e também a de autores contemporâneos, como Chesnais, Duménil e 
Levy. A exposição do processo de financeirização não se dará de forma extensiva, mas apenas com o necessário para prosseguirmos da melhor forma na análise do nosso objeto de estudo - a dominância financeira e sua relação com a saúde.

Em primeiro lugar, é importante esclarecer que aqui usaremos a palavra "finança" na forma como conceituada acima por Duménil e Lévy, distinguindo, portanto, finança - ator político e econômico - de capital financeiro (ou capital portador de juros), que conceituaremos mais a frente.

Enquanto ator político, a finança é ao mesmo tempo criadora e criatura do processo que denominamos de "mundialização financeira". A expressão "mundialização financeira" se refere às "estreitas interligações entre os sistemas monetários e os mercados financeiros nacionais" (CHESNAIS, 1998, p.11), que se desenvolveram mais rapidamente após as medidas de liberalização dos fluxos de capital e desregulamentação que tiveram lugar a partir do ano de $1979^{10}$. Nesse novo período, não houve somente uma maior liberdade para a movimentação financeira internacional, resultando no enorme crescimento na quantidade e volume de transações financeiras, mas principalmente uma mudança qualitativa no papel do capital financeiro no processo de acumulação do capital. Para Chesnais, o momento atual se caracteriza por uma "configuração especifica, na qual o capital portador de juros está localizado no centro das relações econômicas e sociais" (CHESNAIS, 2005, p.35).

A finança seria, portanto, em linhas gerais, o ator político e econômico dominante nesse novo período. Um conjunto que contém uma fração da classe capitalista e "suas"11 instituições financeiras, o que inclui tanto entidades privadas: os bancos privados e os fundos de investimento; entidades estatais ou paraestatais: bancos centrais; e entidades internacionais: o Fundo Monetário Internacional (FMI) e o Banco Mundial, por exemplo.

"Uma característica fundamental da propriedade do capital para esta [fração de] classe é, contudo, que ela é materializada pela posse de títulos, ações e créditos, o que lhe confere o caráter de uma burguesia financeira

\footnotetext{
${ }^{10}$ Mais detalhes sobre como se deram essas medidas de liberalização na seção seguinte.

${ }^{11}$ Aqui o pronome possessivo, assim como utilizado por Duménil e Lévy, cumpre o papel de indicar a dominância política dessa fração de classe sobre essas instituições, mesmo que elas não sejam instituições privadas.
} 
e contribui assim para a justificativa de ser chamada de finança" (DUMÉNIL; LÉVY, 2010, p.189).

Esta fração de classe é definida, portanto, pela posse de um tipo específico de capital, um capital que busca se valorizar na esfera financeira, chamado por Marx de "capital portador de juros". Para Marx, capital é valor empregado na geração de mais valor, podendo tomar nesse processo, diversas formas; dinheiro, mercadoria, máquinas, meios de produção. Aqui o capital "não é uma coisa, mas um processo" (HARVEY, 2013, p.92) e seu valor é definido socialmente. Ou seja, o dinheiro só é capital se empregado socialmente de forma a gerar mais-valor, o mesmo pode ser dito em relação às outras formas de capital; o maquinário de uma indústria, por exemplo, é capital somente se empregado na produção de mercadorias que serão posteriormente vendidas.

Para Marx, portanto, o sujeito só se torna "capitalista" se "adianta" seu dinheiro num processo que, potencialmente, lhe permitirá se apropriar de mais-valor. Se somente guarda seu dinheiro embaixo do colchão, sem coloca-lo à circulação para gerar mais-valor, não é capitalista, mas entesourador. A fórmula básica utilizada por ele para explicar esse processo é D - M - D' (onde D' = D $+\Delta D$ ), ou seja, é um processo no qual o capitalista adianta seu dinheiro (D) na compra de mercadorias $(M)$ só para então vendê-las pela quantia de dinheiro inicialmente adiantada $(D)$ mais um incremento $(\Delta D)$ - o mais-valor ${ }^{12}$.

"Esse impulso absoluto de enriquecimento, essa caça apaixonada ao valor é comum ao capitalista e ao entesourador, mas, enquanto o entesourador é apenas o capitalista ensandecido, o capitalista é o entesourador racional. $\mathrm{O}$ aumento incessante do valor, objetivo que o entesourador procura atingir conservando seu dinheiro fora da circulação, é atingido pelo capitalista, que, mais inteligente, lança sempre o dinheiro de novo em circulação" (MARX, 2013, p.229).

A operação D - M - D, no qual o indivíduo compra uma mercadoria para em seguida vendê-la pelo mesmo exato valor, seria "tão despropositada quanto absurda" (MARX, 2013, p.226). É somente pela potencialidade de apropriar-se do mais-valor que o capitalista coloca seu dinheiro em circulação. Caso contrário,

12 A mercadoria que o capitalista compra e que o permite, ao final, se apropriar de um valor excedente é a força de trabalho. É o trabalho realizado pelo trabalhador que gera o mais-valor, que por sua vez só se realiza na circulação, quando a mercadoria é finalmente vendida a seu consumidor final. 
poderia simplesmente fazer como o entesourador, e manter seu dinheiro guardado sem correr o risco de acabar por receber menos do que adiantou.

Como não poderia deixar de ser, o dinheiro que é emprestado de um capitalista ao outro, se tornando capital portador de juros, também só entra em circulação sob o objetivo de se valorizar. A remuneração que recebe, ao final, o capitalista que empresta - o prestamista - provém de uma parte do mais-valor obtido pelo capitalista que produz - o capitalista produtivo. Ou seja, o capitalista produtivo empresta dinheiro do prestamista, o aplica como capital na produção, e, ao final, devolve o dinheiro que tinha tomado emprestado, mais uma parte do maisvalor que conseguiu se apropriar na produção e venda de mercadorias. Decorre daí, portanto, que o juro aqui nada mais é que uma parte do lucro.

Apesar disso, a restituição do empréstimo do capitalista produtivo ao prestamista não depende da realização bem sucedida da produção e venda da mercadoria viabilizada pelo empréstimo, ela é antes determinada em contrato no momento do empréstimo. Se algo de errado ocorrer, e o capitalista produtivo não conseguir, através da aplicação daquele empréstimo, se apropriar do mais-valor necessário ao pagamento dos juros, terá de buscar outros meios para pagar o prestamista.

"De modo que o refluxo do capital, com respeito a essa transação, já não aparece como resultado determinado pelo processo de produção, mas como se o capital emprestado nunca tivesse perdido a forma de dinheiro" (MARX, 1986a, p.262).

Ou seja, para o prestamista, é como se o dinheiro que empresta, o seu capital portador de juros, fosse capaz de se valorizar sem passar pelo processo produtivo, de se autovalorizar diretamente, como D - D'. É como se as fantasias mais tórridas do entesourador tivessem se tornado realidade, e ele fosse capaz aqui de fazer seu dinheiro se valorizar diretamente, sem nunca precisar se transmutar em mercadoria.

"Na forma do capital portador de juros, portanto, esse fetiche automático está elaborado em sua pureza, valor que valoriza a si mesmo, dinheiro que gera dinheiro, e ele não traz nenhuma marca de seu nascimento. A relação social está consumada como relação de uma coisa, do dinheiro, consigo mesmo. Em vez da transformação real do dinheiro em capital aqui se mostra apenas sua forma sem conteúdo. Como no caso da força de trabalho, o valor de uso do dinheiro torna-se aqui o de criar valor, valor maior que o contido nele mesmo. O dinheiro como tal já é potencialmente valor que se valoriza, e como tal é emprestado, o que constitui a forma de 
venda dessa mercadoria peculiar. Torna-se assim propriedade do dinheiro criar valor, proporcionar juros, assim como a de uma pereira é dar peras" (MARX 1986a, p.294).

Portanto, muito embora o dinheiro não possa gerar valor por si próprio, (propriedade da força de trabalho inserida num processo de produção e circulação de mercadorias), ele toma para si, de forma fetichizada, essa propriedade. O que acontece, por exemplo, se o capitalista produtivo não consegue realizar o mais-valor e também não pode de nenhuma outra forma pagar o prestamista? O prestamista deixa de receber os seus juros, e é revelada a dependência do capital portador de juros, no que se refere à apropriação de mais-valor, de sua aplicação enquanto capital produtivo. "O capital portador de juros só se afirma como tal à medida que o dinheiro emprestado é realmente transformado em capital e se produz um excedente, do qual o juro é uma parte" (MARX, 1986a, p.285).

É desse fetichismo do capital portador de juros - dinheiro emprestado ao capitalista produtivo para a apropriação de mais-valor e o pagamento de juros - que deriva o que Marx chama de capital fictício.

Como explica Marx (1986b, p.10), devido ao fetichismo da forma do capital portador de juros, espera-se desses títulos certo rendimento, mesmo que esse dinheiro não tenha sido aplicado como capital, ou seja, mesmo que não tenha sido utilizado para "extrair dos trabalhadores determinado quantum de trabalho não-pago" (MARX, 1986a, p. 255). Em outras palavras, o capital fictício não é capital strictu sensu, pois não está aplicado a uma atividade ou processo que produza valor. Ainda assim, devido à capacidade "mágica" de por "ovos de ouro" que o dinheiro adquire a partir de sua fetichização, espera-se que todo dinheiro seja remunerado como capital ${ }^{13}$.

13 Para Harvey, "o fetichismo, como definido no Livro I, é real e objetivo, mesmo quando esconde relações de valor subjacentes. A mercadoria é realmente trocada por dinheiro no supermercado, mas a maneira como ela faz isso esconde informação sobre o trabalho (valor) que entrou em sua criação. O capital fictício tem de ser entendido do mesmo modo. Ele não é produto da mente delirante de um banqueiro cocainômano de Wall Street, mas uma forma real de capital - dinheiro que se tornou mercadoria, dotada de um preço. Embora o preço seja fictício, somos todos forçados a responder por ele (seja pagando uma hipoteca, procurando juros para a nossa poupança ou contraindo empréstimos para alavancar um negócio)" (HARVEY, 2014, p.172). Harvey retoma nesse trecho sua discussão do fetichismo em Marx. Para ele a questão está em como as relações reais subjacentes são encobertas pela aparência cotidiana. Aqui, muito embora as "relações de valor" estejam mistificadas, ou seja, mesmo que o capital fictício não participe do processo de criação de valor (e, nesse aspecto, não seja capital), acaba assumindo, na prática, a forma de um capital. Num trecho do capítulo XXIX do Livro III, o próprio Marx comenta: "Nesses fatos, de que até uma acumulação de 
A dívida pública aparece como exemplo de capital fictício:

"Mas, em todos esses casos, o capital, do qual o pagamento feito pelo Estado considera-se um fruto (juro), permanece capital ilusório, fictício. A soma que foi emprestada ao Estado já não existe ao todo. Ela em geral jamais se destinou a ser despendida, investida como capital, e apenas por seu investimento como capital ela teria podido converter-se num valor que se conserva. Para o credor original A, a parte que the cabe dos impostos anuais representa o juro de seu capital, do mesmo modo que para o usurário, a parte que the cabe do patrimônio do pródigo, embora em ambos os casos a soma emprestada de dinheiro não tenha sido despendida como capital". (MARX, 1986b, p. 10).

Marx também aponta o aspecto fictício dos títulos de propriedade das empresas - as ações. Muito embora sejam títulos sobre o capital real, não são o próprio capital, mas duplicatas. Enquanto esses títulos podem ser comprados e vendidos a qualquer momento, o capital real, pelo qual esses títulos respondem, está imobilizado na empresa e não pode ser disposto pelo proprietário desses títulos. A compra e venda deles, portanto, não é a compra e venda de capital real, mas somente a negociação dos direitos sobre o rendimento desse capital. Os preços pelo quais esses títulos são comprados e vendidos, e suas variações diárias, muitas vezes independem do "movimento do valor do capital real".

"Mesmo lá onde o título de dívida - o título de valor - não representa, como no caso das dívidas públicas, um capital puramente ilusório, o valor-capital desse título é puramente ilusório. Viu-se acima como o sistema de crédito gera capital associado. Os papéis são considerados títulos de propriedade que representam esse capital. As ações de companhias ferroviárias, de mineração, de navegação etc. representam capital real, a saber, o capital investido e que funciona nessas empresas, ou a soma de dinheiro que é adiantada pelos sócios para ser despendida em tais empresas como capital. Do que não se exclui, de modo algum, a possibilidade de que representem mera fraude. Mas esse capital não existe duplamente, uma vez como valor-capital dos títulos de propriedade, das ações, e outra vez como capital realmente investido ou a investir naquelas empresas. Ele existe apenas nesta última forma, e a ação nada mais é que um título de propriedade, pro rata, sobre a mais-valia a realizar por aquele capital. A pode vender esse título a $B$ e $B$ a $C$. Essas transações em nada alteram a natureza da coisa. A ou B transformou então seu título em capital, mas $C$ transformou seu capital em mero título de propriedade sobre a mais valia a ser esperada do capital acionário" (MARX, 1986b, p.11).

dívidas pode aparecer como acumulação de capital, se revela o ápice da distorção que tem lugar no sistema de crédito. Esses certificados de dívida, que são emitidos sobre o capital originalmente emprestado e há muito despendido, essas duplicatas de papel de capital extinto, funcionam como capital para seus proprietários na medida em que são mercadorias vendáveis e, por isso, podem ser retransformados em capital" (MARX, 1986b, p.19). 


\subsubsection{A exterioridade da finança}

Enquanto fração de classe, a finança, ator político ao qual vínhamos nos referindo, se caracteriza, principalmente, pela posse de capital portador de juros, sejam esses "juros" provenientes do processo real de valorização ou simplesmente capital fictício. A valorização de seu capital se dá de modo externo ao processo de criação e apropriação do mais-valor na produção. Ao contrário do capitalista produtivo, que recebe seu lucro da conclusão bem sucedida do ciclo de criação e apropriação de mais-valor, aplicando seu dinheiro diretamente na produção de mercadorias e explorando a força de trabalho, a remuneração do capitalista financeiro, enquanto prestamista, aparece como simples remuneração pela posse do capital.

A exterioridade da finança em relação à produção trata, portanto, de sua distância em relação às atividades produtivas. Ela aparece aqui como expressão dessa forte diferenciação entre juro e lucro e da relação "ao menos parcialmente antagônica" (Chesnais 2010, p.116) entre os dois tipos de capitalistas. Segundo Marx, tem-se que:

"o capital portador de juros como tal tem como sua antítese não o trabalho assalariado, mas o capital funcionante; o capitalista prestamista como tal confronta diretamente o capitalista realmente funcionante no processo de reprodução, e não o trabalhador assalariado que, exatamente na base da produção capitalista, é expropriado dos meios de produção. O capital portador de juros é o capital enquanto propriedade em confronto com o capital enquanto função" (MARX 1986b, p.283).

Essa distância do capital-propriedade do processo de valorização e sua exigência de remuneração em forma de juro, independente do que acontece no processo de valorização, é motivo de tensão na sua relação para com o capitalfunção. Para Chesnais (2005, p.53-54), uma das principais repercussões do processo de liberalização financeira e reativação das bolsas de valores a partir da década de 1980, é que a finança conseguiu alojar no cerne dos grupos industriais o tipo de exigência de rentabilidade típica do capital portador de juros. Isso foi possível graças à liquidez provida pelas bolsas, que permitem aos acionistas se desfazer das ações cujo desempenho não satisfizesse seu padrão de rentabilidade e também devido à liberalização dos fluxos monetários, garantindo aos investidores a possibilidade de transitar rapidamente de um mercado a outro. 
Os fundos de pensão e de investimento cumprem um papel importante nesse novo quadro, pois neles os direitos de capital-propriedade de um grande número de pequenos poupadores são delegados a administradores financeiros, que exigem rendimentos estáveis muito elevados, muitas vezes estabelecidos em comparação com o rendimento de títulos de capital fictício, como o título da dívida pública. Tal pressão para a rentabilidade foi tal que, segundo Chesnais, "foi necessária apenas uma curta década" (2005, p.54) para que, nos grandes grupos industriais, o antigo administrador tecnocrático do pós-guerra fosse substituído por administradores do tipo financeiro. "Mas suas prioridades são muito diferentes das do administradorindustrial que ele substituiu. Os grupos são dirigidos por pessoas para as quais a tendência da Bolsa é mais importante do que qualquer outra coisa" (CHESNAIS 2005, p.54).

Essa captura dos grandes grupos industriais pela lógica da valorização financeira foi responsável por uma verdadeira "remodelagem" de tais grupos.

"Face ao objetivo de maximização do valor acionário para responder às exigências dos mercados e à intensificação da concorrência, os dirigentes de empresas privilegiaram as medidas que encontram as "preferências" da coletividade de investidores: redução dos custos por meio de um conjunto de demissões maciças, restruturação de grupos em torno dos segmentos com atividades mais rentáveis, programas recorrentes de recompra de ações e sobretudo de downsizing (diminuição de tamanho) e externalização das operações" (CHESNAIS, 2010, p.162).

Esse processo de reestruturação também envolveu mudanças para facilitar o controle da finança sobre a produção. O grande número de fusões e aquisições das décadas de 1980 e 1990 fez diminuir consideravelmente a quantidade de grupos industriais em cada setor. De modo a lidar com a "preferência pela liquidez", exacerbada no novo período, a própria forma jurídica da propriedade desses grupos sofreu mudanças, com o surgimento da "holding financeira". A holding é uma empresa que emprega diretamente somente algumas centenas de funcionários, mas que pode apresentar uma vasta rede de filiais, tanto de empresas puramente financeiras, como também as produtivas. São essas filiais produtivas que terão de enfrentar a tarefa de organizar a extração de valor por meio da produção. Normalmente transnacionais, essas filiais de produção também externalizam a produção em direção a empresas menores, com as quais estabelecem contratos de 
subcontratação e "parcerias", jogando para ainda mais longe de si os loci de extração de mais-valor e os riscos associados à produção.

Essa nova configuração dos grandes grupos industriais teve repercussões importantíssimas para a relação entre capital e trabalho no mundo todo. A externalização da produção, tanto nacionalmente através das terceirizações, como internacionalmente, através das transferências de tais atividades para outros países, foi um duro golpe sobre o trabalho organizado. Sobre isso, Chesnais comenta:

"A externalização em grande escala precedeu e preparou a flexibilização e a precarização. Antes de poder se impor ao fator trabalho por meio de políticas de flexibilidade e de precariedade, um equivalente da propriedade líquida que o mercado financeiro dota o capital, era necessário ter acabado com as grandes unidades de produção. Era necessário que a tarefa de disciplinar os assalariados fosse transferida a empresas pequenas e vulneráveis, e portanto feroz em sua vontade de maximizar a quantidade de trabalho fornecida por seus assalariados" (CHESNAIS, 2010, p.165).

Essa nova configuração das empresas e dos grupos industriais é adaptada para "extrair o máximo da liberalização e da desregulamentação dos movimentos de capitais, das trocas e dos investimentos diretos no estrangeiro" (CHESNAIS, 2010, p.163), sendo, de certa forma, consequência direta da existência de tais condições.

É justamente esse contexto de exterioridade da finança que torna ainda mais preocupante a abertura da assistência à saúde ao capital internacional, no Brasil. Com base na experiência internacional, são esperadas reestruturações que podem distorcer negativamente tanto a oferta de serviços de saúde como a sua qualidade (RELMAN, 1980).

A seguir discutiremos brevemente alguns elementos históricos da dominância financeira no Brasil e no mundo.

\subsubsection{A nova hegemonia financeira}

Nos últimos trinta anos, os proprietários do capital portador de juros, os administradores da alta finança e suas instituições vem usufruindo imensa liberdade de ação e poder político, mas houve um momento em que as coisas foram um pouco diferentes. Para Duménil e Lévy, o conceito de finança só é pertinente no capitalismo moderno, do início do século XX até os dias de hoje. De lá para cá, seria possível dizer que há "hegemonia financeira" quando o poder da finança é forte 
(DUMÉNIL; LÉVY, 2010). Eles apontam um primeiro período de hegemonia que durou do início do século XX até a crise de 1929 e um segundo período que vai do início dos anos 1980 e se estenderia até hoje. Esse dois períodos teriam sido separados por um momento no qual esse tipo de capital teria seu movimento controlado e seu poder decisivamente diminuído; do início dos anos 1930 até a primeira metade dos anos 1970 (DUMÉNIL; LÉVY, 2005).

O período do pós-guerra é chamado por muitos de a "Era de Ouro" do capitalismo. A reconstrução da Europa, assim como a atuação (mais ou menos) concertada dos governos em direção ao emprego e ao crescimento, garantiram duas décadas de crescimento econômico como nunca antes (e nunca depois) visto (HOBSBAWM, 1995). Para Duménil e Lévy (2010, p.215), foi um período em que "a fração superior da classe capitalista e suas instituições financeiras se viram contidas" e em que "parte dos mecanismos financeiros foi colocada a serviço do desenvolvimento". Enquanto as taxas de crescimento econômico se mantiveram altas, o chamado "compromisso keynesiano", com o controle do câmbio, dos fluxos de capitais e um sistema financeiro sob rígida regulação, se manteve.

Para Chesnais (2005, p.37), foi, no entanto, nas décadas de 1950 (EUA) e 1960 (Europa), muito antes da crise aberta do modo de regulação fordista, na década de 1970, que um processo de centralização sob a forma financeira começou "sem que se lhe preste muita atenção". Essa centralização seria um subproduto da acumulação industrial dos "anos gloriosos" e teria sido impulsionada tanto pelo investimento das famílias de mais alta renda em seguros de vida (estimuladas por incentivos fiscais), como pela obrigatoriedade, nos anos 1960, dos trabalhadores abrirem contas em bancos (ou no correio) para receberem seus salários, que passavam de semanais para mensais.

"Uma massa considerável de dinheiro líquido, que antes escapava dos bancos, afluiu em direção a eles. Isso aumentou a escala de suas operações de crédito, bem como de aplicações a curto ou muito curto prazo com a mais alta remuneração que eles podiam obter no dia em que um mercado financeiro desregulamentado foi reconstituído" (CHESNAIS, 2005).

Essa reconstituição se deu em 1958, com a criação, na City de Londres, de um estatuto offshore que permitia a livre circulação de dólares, com regras próximas a de um paraíso fiscal. Num mundo em que a circulação de dinheiro era controlada 
de forma bastante rígida, o novo "mercado de eurodólares", como veio a ser chamado, passou a atrair o lucro não reinvestido (e não repatriado) das subsidiárias americanas do mundo todo (CHESNAIS, 2005, p.38).

Mas é somente no início da década de 1970 que o "compromisso keynesiano" começa a desmoronar, tanto nacional como internacionalmente. Com "sinais de uma grave crise de acumulação aparentes em todo lugar" (HARVEY, 2014), uma finança em vias de se reconstituir e com o virtual abandono de Bretton Woods após 1971 ${ }^{14}$, "a pressão das instituições financeiras em favor da livre circulação do capital tornase mais e mais forte" (DUMÉNIL; LÉVY, 2010, p.216).

Para Harvey (2014), aquele era um momento decisivo para as classes mais altas. Embora sua participação na renda nacional ${ }^{15}$ e seu poder político já estivessem relativamente menores desde a Segunda Guerra, o conjunto de estagnação econômica e inflação, combinado com o crescimento da esquerda na Europa Ocidental e, de certa forma, mesmo nos EUA, constituía uma ameaça maior, tanto política como economicamente. A virada neoliberal estaria associada com uma retomada de poder por parte da classe proprietária ${ }^{16}$.

Com a progressiva queda da taxa de lucro do capital industrial nos países centrais, houve aumento importante do fluxo de dinheiro em busca de espaços de valorização. A industrialização da periferia (o Brasil incluído) cumpriria aí um duplo papel, tanto como "praça" de investimento para o capital industrial em busca de taxas de lucro mais favoráveis, como também na construção de novos mecanismos de valorização para um setor financeiro "em vias de expansão e autonomização" (PAULANI, 2008, p.88) ${ }^{17}$.

\footnotetext{
${ }^{14}$ Em agosto de 1971, os EUA, do presidente Richard Nixon, decidem unilateralmente abandonar a conversibilidade do dólar em ouro. Uma vez que, desde Bretton Woods, o dólar funcionava também como moeda mundial, a conversibilidade em ouro era uma garantia para os outros governos, e uma das partes mais importantes do acordo.

${ }^{15}$ A participação do $1 \%$ mais rico na renda nacional dos EUA cai de um valor pré-guerra de $16 \%$, para $8 \%$ ao fim da Segunda Guerra, se mantendo próximo a esse nível por três décadas (HARVEY, 2014).

${ }^{16}$ Após 1979, com Margareth Thatcher tornando-se primeira ministra no Reino Unido e 1981, com Reagan presidente dos EUA, essa reação toma contornos mais concretos. O discurso e as políticas de ambos os governos passaria a representar um modelo a ser seguido até mesmo por seus adversários políticos (Blair e Clinton), no que viríamos a chamar de Hegemonia Neoliberal.

${ }_{17}$ Os mecanismos de valorização que a esfera financeira começara a criar, da qual fala Leda Paulani, são, por exemplo, as colossais transferências de renda permitidas pelas dívidas públicas dos países, a partir dali.
} 
Os abruptos aumentos dos preços do petróleo a partir de 1973 foram um acontecimento decisivo na construção dessa nova hegemonia financeira, principalmente nos países do então chamado "terceiro mundo". Além de impor aos países importadores de petróleo dificuldades na sua balança comercial ${ }^{18}$, geraram uma enorme massa de dinheiro afluindo à City londrina em busca de valorização; processo conhecido como a "reciclagem" dos petrodólares, conforme descreve Chesnais.

\begin{abstract}
"Essa "reciclagem" tomou a forma de empréstimos e de abertura de linhas de crédito dos bancos internacionais aos governos do Terceiro Mundo, sobretudo na América Latina. As bases da dívida do Terceiro Mundo foram lançadas e, com elas, um mecanismo de transferência de recursos que possui a capacidade de se reproduzir no tempo" (CHESNAIS, 2005, p.39).
\end{abstract}

Os empréstimos a juros baixos (porém flutuantes) provenientes da "reciclagem" dos petrodólares inundaram os países do leste europeu, do norte da África e da América Latina, e com o Brasil não foi diferente (SAFATLE, 2012). Para Oliveira (2003, p.132), o recurso ao financiamento externo apareceu para o Brasil naquele momento como "solução" para garantir o crescimento econômico sem "resolver o agudo problema do financiamento interno da expansão do capital" e nem "liquidar com o patrimonialismo"19.

É somente em 1979, no entanto, que o endividamento dos países periféricos toma proporções dramáticas. Enfrentando um misto de baixo crescimento e alta inflação por toda a década de 1970, os EUA chegaram ao final dela com uma inflação anual de até dois dígitos e um dólar em franca desvalorização. Em 1979 o democrata Paul Volcker foi indicado para presidente do Federal Reserve System $(\text { Fed })^{20}$ e iniciou uma política de alta de juros e valorização da moeda (EICHENGREEN, 2008). Juntamente com medidas para a liberação dos mercados de títulos da dívida pública, a política do Fed a partir de 1979 é considerada por Chesnais (2005, p.39-40) como o "golpe de Estado" que institui a "ditadura dos "credores'". A multiplicação por três ou quatro das taxas de juros a serem pagas

\footnotetext{
18 No caso do Brasil, essas dificuldades se deram tanto pelo próprio aumento no preço do petróleo, que importava, como também pela diminuição das exportações aos países centrais, em crise (CRUZ, 1984).

${ }^{19} \mathrm{O}$ processo de endividamento para financiar o crescimento econômico no Brasil já tinha começado no governo Médici (1969-1974), antes do aumento nos preços do petróleo, mas foi após 1973, principalmente no governo Geisel (1974-1979), que a entrada de capital estrangeiro por meio de empréstimos tomou uma maior importância (CRUZ, 1984).

${ }^{20}$ O Federal Reserve System, ou simplesmente "Fed", cumpre a função de Banco Central nos EUA.
} 
pelos empréstimos "baratos" de anos antes, precipitou a crise da dívida no "terceiro mundo" na década de 1980.

Os empréstimos concedidos aos países periféricos não foram os mais importantes (do ponto de vista da acumulação financeira) para o verdadeiro fortalecimento do sistema financeiro internacional, esse papel foi cumprido pela dívida dos países centrais, muito maior em volume. Mas certamente as dívidas dos países periféricos se tornaram uma importante ferramenta de controle político nas décadas que se seguiram. Foram essas dívidas que permitiram a imposição dos "ajustes estruturais", tão famosos na América Latina dos anos 1980 e 1990 (CHESNAIS 2005, p.40).

Segundo Paulani (2008, p.88), a industrialização da periferia na década de 1970 seria uma primeira etapa da dominação financeira, na qual "a periferia aparece como a demanda que faltava num mundo em crise aberta depois do choque do petróleo". O encerramento dessa etapa após o "efeito Volcker" - e a crise da dívida que se seguiu nos anos 1980 - permitiu a imposição dos ajustes estruturais que anunciariam uma segunda fase, na qual países como o Brasil passariam a apresentar as condições institucionais (a liquidez dos ativos cotados em bolsas, desregulamentação do sistema financeiro, governos comprometidos com o superávit primário, etc) para servir como "locus de valorização financeira".

\subsubsection{O Brasil e sua inserção na mundialização financeira ${ }^{21}$}

Até o final da década de 1980, o Brasil não apresentava as condições necessárias para inaugurar essa segunda etapa e servir como "plataforma de valorização financeira internacional”. Uma política cambial fortemente centralizada e regulada, uma alta inflação (de pelo menos dois dígitos ao mês) e uma consequente dificuldade de mensurar (e controlar) os gastos do Estado, não eram compatíveis com as exigências da finança. Paulani descreve esse momento:

"Tendo em vista o caráter rentista desse tipo de acumulação, e considerando que uma de suas bases mais importantes é a dívida pública, a anarquia nos gastos públicos produzida pela alta inflação era uma complicação e tanto, pois precarizava a extração de renda real que deve

${ }^{21}$ Essa seção se apoia no trabalho de Paulani e Pato (2008). 
valorizar esse "capital caído do céu", em que se constituem esses papéis" (PAULANI, 2008, p.94) ${ }^{22}$.

Com o avanço do discurso neoliberal, o tamanho e os gastos do Estado passam a ser um tema capital. Já em 1989, com a eleição de Collor e seu lema de "caça as marajás", "reduzir o Estado" e "controlar os gastos públicos" passa a tomar a condição de imperativo. Segundo esse discurso, o "inchado" Estado brasileiro seria a "herança perversa" de um tempo em que se acreditava que o desenvolvimento aqui só seria possível com um Estado forte e interventor. Para essa visão econômica ortodoxa, um Estado com tantas responsabilidades não seria capaz de garantir uma boa gestão orçamentária e uma moeda equilibrada. Mais importante que isso, poderia vir a comprometer o pagamento em dia dos papéis da dívida pública ${ }^{23}$.

Se visto por esse lado, da garantia da rentabilidade do capital, seria possível dizer também que havia também outros "problemas". A lei de falências da época colocava as dívidas trabalhistas e tributárias à frente das dívidas financeiras. $\mathrm{O}$ sistema previdenciário brasileiro, além de representar um gasto importante para o orçamento público, inibia o surgimento de um mercado privado mais forte, importantíssimo para a acumulação financeira. Não havia instrumentos institucionais fortes o bastante para disciplinar os governantes no pagamento da dívida pública, e a Constituição Federal de 1988 instituía um orçamento público com muitas vinculações obrigatórias, intensificando o "problema".

Esses "obstáculos" para que o Brasil se tornasse um "mercado emergente" começaram a ser enfrentados na década de 1990. Foi justamente o "caçador de marajás" Fernando Collor de Mello que iniciou, no seu curto governo, a implementação do Consenso de Washington ${ }^{24}$ no Brasil, com a privatização de algumas empresas estatais. As medidas de peso para adaptar o Brasil a seu novo papel no processo de mundialização financeira, no entanto, teriam lugar somente a partir do governo de Itamar Franco. Em 1992, em meio a negociações para

${ }^{22}$ Quando fala de "capital caído do céu", Paulani se refere à seu caráter de capital fictício, discutido na seção 1.2 .

${ }^{23}$ Para essa visão, ver Giambiagi (2005).

24 O Consenso de Washington foi um termo cunhado em 1989 pelo economista John Williamson para designar o que seria o conjunto de medidas defendidas pelas instituições "de Washington" (como o FMI, Banco Mundial, Fed) para as economias da America Latina. Hoje o termo é amplamente usado como sinônimo para o receituário neoliberal (WILLIAMSON, 2009). 
securitizar a divida externa e internacionalizar o mercado brasileiro de títulos públicos, a diretoria da área externa do Banco Central lançou uma "carta circular" que, na prática, liberava a remessa de recursos em moeda forte ao exterior ${ }^{25}$.

A abertura financeira formal não teria, no entanto, os efeitos esperados se a inflação não fosse controlada. O Plano Real cumpre esse papel, estabilizando a moeda, e abrindo espaço para as outras reformas que viriam. Eleito presidente em 1994 como "pai" do Plano Real, Fernando Henrique Cardoso (FHC) faria tudo a partir dali sob o signo da estabilidade monetária. Segundo a sua visão, o aumento dos juros, a privatização das empresas estatais, a derrubada das barreiras comerciais, a manutenção de um Real sobrevalorizado - tudo isso seria importantíssimo para, mantendo-se a estabilidade, aumentar a produtividade da economia brasileira e garantir o lugar do país na nova economia globalizada (FRANCO, 1998) ${ }^{26}$.

Os dispositivos da Constituição de 1988 e vinculações obrigatórias que garantiriam o financiamento da Seguridade Social e da Saúde nunca foram completamente respeitados, sendo desde o início fontes de conflitos dentro do governo federal. Apesar disso, algumas medidas como a instituição do Fundo Social de Emergência - criado em 1994 e que a partir do ano 2000 seria chamado de Desvinculação das Receitas da União (DRU) ${ }^{27}$ - sacramentaram o desfinanciamento das áreas sociais em benefício do superávit primário, utilizado para a remuneração do capital portador de juros (MENDES, 2012, p.120). FHC inicia seu mandato em 1995 e passa a enfrentar a questão do tamanho do Estado. Além de continuar as privatizações iniciadas no governo Collor, inicia também um processo de "reforma do aparelho do Estado" que visava tanto retirar da administração direta do Estado a

25 Tal operação teria sido ilegal, pois por meio de simples "carta circular", que a princípio deveria servir somente para esclarecer normas ou regulamentos, acabou por modificar uma lei federal de 1962. Tudo isso sem a anuência do Congresso Nacional.

26 Para Franco (1998), não haveria qualquer tipo de incongruência entre a política adotada naquele momento por $\mathrm{FHC}$ e o crescimento econômico, pelo contrário. A restruturação produtiva ensejada pelas políticas austeras credenciaria o Brasil para um futuro de crescimento sustentado, segurança e até mesmo diminuição da desigualdade. O importante era superar o cenário dos anos 1980, a "década perdida". Paulani (2008) mostra, no entanto, que além do aumento da vulnerabilidade externa (evidenciado pelas crises de 1998 e 2001), desemprego recorde e piora da pobreza absoluta, o crescimento do PIB na década de 1990 foi de apenas 19,04\%, com um aumento do PIB per capita de apenas $1,57 \%$. Na atribulada década de 1980 , o PIB havia crescido $33,4 \%$ e o PIB per capita $10,13 \%$.

27 A Desvinculação das Receitas da União (DRU), entre outros aspectos, desvincula $20 \%$ da arrecadação das contribuições sociais de sua finalidade e as tornam disponíveis para uso do governo federal. 
maioria dos serviços públicos, como reformar o sistema previdenciário (BRASIL, 1995). O Plano Diretor da Reforma do Aparelho do Estado (PDRAE), do então ministro Luís Carlos Bresser Pereira, fala em substituir a "administração burocrática", até então vigente, por uma "administração gerencial". Enquanto as privatizações buscavam atrair o capital estrangeiro e acelerar a "integração da economia nacional" no processo de globalização, as reformas gerenciais ajudariam a "enxugar o orçamento"28.

A aprovação, em 2000, da Lei de Responsabilidade Fiscal (LRF), vem para garantir a disciplina dos governantes na construção de superávits primários para o pagamento da dívida. Ela tem papel importante também na terceirização do setor público. Já tendo apresentado o plano para reestruturar o aparelho do Estado com o PDRAE, em 1995, e, posteriormente, construído as prerrogativas legais para a terceirização dos serviços públicos - cujo exemplo importante é a lei no 9637/98, que cria as Organizações Sociais - a LRF completa o quadro, colocando tetos nos gastos com recursos humanos de cada esfera, de modo a obrigar os governos a abrir mão da contratação direta de servidores para a execução de serviços básicos, como a saúde.

FHC também conseguiu fazer parte das reformas exigidas pela finança no sistema previdenciário, modificando a previdência dos trabalhadores do setor privado e abrindo espaço para a constituição de um mercado privado de previdência. Essas mudanças feitas por FHC só foram implementadas à previdência dos trabalhadores do setor público no governo Lula.

Longe de reverter as medidas implementadas na década de 1990, portanto, o primeiro governo Lula (2003 - 2006) as aprofundou. Além da reforma da previdência do setor público, seu governo garantiu, em 2005, uma nova lei de falências, que apesar de manter o gasto com dívidas trabalhistas em primeiro lugar, os limitava em $\mathrm{R} \$ 39$ mil, colocando as dívidas financeiras logo em seguida, à frente das dívidas tributárias. A prorrogação e ampliação da DRU, a autonomia do Banco Central, e as novas medidas de liberalização financeira não deixariam dúvidas quanto ao papel

28 O texto do PDRAE falava em "programa de publicização", em "valorizar o servidor público, propiciando-Ihe motivação profissional, remuneração condizente com o mercado de trabalho nacional, além de razoável segurança no emprego" e que acabariam "proporcionando maior abrangência e promovendo melhor qualidade para os serviços sociais" (BRASIL, 1995). Esse tema é retomado no Capítulo 3. 
que esse governo estava a cumprir na adaptação do Brasil ao papel de "plataforma de valorização financeira internacional”.

Para Oliveira (2003), tais "convergências pragmáticas" entre os governos do PSDB e do PT são explicadas principalmente: pela erosão das forças do trabalho, ensejada pelas reestruturações produtivas que tomaram lugar a partir da década de 1980, fazendo com que a representação do movimento operário perdesse sua base; e pela ascensão de parte da antiga burocracia sindical à administrações dos grandes fundos de pensão das antigas estatais, fazendo com que passassem diretamente de representantes dos trabalhadores para administradores da fundos de pensão. Oliveira argumenta que:

"É isso que explica recentes convergências pragmáticas entre o PT e o
PSDB, o aparente paradoxo de que o governo Lula realiza o programa de
FHC, radicalizando-o: não se trata de equívoco, nem de tomada de
empréstimo de programa, mas de uma verdadeira nova classe social, que
se estrutura sobre, de um lado, técnicos e economistas doublés de
banqueiros, núcleo duro do PSDB, e trabalhadores transformados em
operadores de fundos de previdência, núcleo duro do PT. A identidade dos
dois casos reside no controle do acesso aos fundos públicos, no
conhecimento do 'mapa da mina"” (OLIVEIRA, 2003, p.147).

O conjunto de contrarreformas iniciadas no início da década 1990 e ainda em curso (como a atual restrição no acesso a benefícios previdenciários, como o seguro desemprego) dá uma medida do poder que a finança exerce sobre o orçamento público hoje no Brasil. As medidas que "agradam os mercados" nada mais são do que aquelas que garantem uma fatia cada vez maior do orçamento público para o pagamento dos rentistas.

Mas o problema está longe de se limitar ao comprometimento do fundo público com os rendimentos da finança, as políticas implementadas nesses últimos 25 anos afetam gravemente o conjunto da economia. A "combinação de uma política de juros extremamente elevados com uma cancela financeira cada vez mais escancarada" (PAULANI, 2013, p.254) fez da economia brasileira também o palco perfeito para a valorização do capital portador de juros, aumentando assim a dependência e a vulnerabilidade externas. Dadas as garantias de liquidez e a liberdade dos fluxos financeiros atualmente vigentes, as exigências de rentabilidade da finança convertem-se em poderosíssimos imperativos políticos, uma vez que 
medidas que "desagradem os mercados" podem resultar em violentas fugas de capitais e importantes abalos na economia.

É nesse contexto de crise e de dominância do capital portador de juros que tem se dado a construção do SUS. O contraste entre a quantidade de recursos empregados no pagamento da dívida pública e aqueles empregados no financiamento do SUS ${ }^{29}$ é certamente um dos exemplos mais notáveis dos constrangimentos que as exigências da finança impõem ao direito à saúde, mas não se encerram aí. A crescente participação do setor privado nos gastos em saúde nas últimas décadas, financiada, em parte, com isenções fiscais, aprofunda a fragilidade do setor público e se configura como um desafio para a efetivação do direito à saúde universal, equânime e integral.

Nesse cenário de dificuldade para a efetivação do direito e avanço da finança, com o capital em busca de novos espaços de valorização, é que se insere também a crescente participação do setor privado na gestão dos serviços públicos de saúde. Essa articulação do setor saúde com a reprodução capitalista, no entanto, não é nova. Desde o princípio da Previdência Social e de seus primeiros arranjos assistenciais, a implementação e a organização dos serviços de saúde está intimamente ligada tanto aos movimentos econômicos como também ao movimento das classes junto ao Estado. É esse o tema que discutiremos no capítulo a seguir.

${ }^{29}$ No ano de 2014 , do orçamento federal efetivamente executado, 45,11\% teriam sido gastos com juros e amortizações da dívida, enquanto somente 3,98\% teriam sido gastos com a saúde (MCCARTHY, 2015). 


\section{A assistência à saúde e a dinâmica da luta de classes numa perspectiva histórica - breve retrospectiva do século $\mathrm{XX}$}

Se durante os anos 1990 e parte dos anos 2000 o Sistema Único de Saúde (SUS) era encarado por muitos de seus defensores como um projeto ainda em implementação, obra social a ser concluída, o sentimento nessa primeira metade da década de 2010 é um tanto diferente. A "saúde universal, equânime e integral" passa a ser encarada não mais somente como promessa inconclusa, mas cada vez mais como direito sob ataque.

A realidade é que a saúde universal brasileira foi, ao longo dos 28 anos de existência do Sistema Único de Saúde, um projeto em construção e um direito social sob ataque. Esse princípio foi introduzido na Constituição Federal de 1988 após mobilização das forças progressistas animadas pelo processo de abertura democrática, mas só passou a ser construído no governo Fernando Collor de Mello, presidente eleito em 1989 com agressiva retórica neoliberal. O SUS nasceu e continuou a ser construído a partir de tais contradições: alcançando façanhas organizativas, mas sob grave subfinanciamento (PAIM et al., 2011); gozando de participação popular em conselhos e conferências por todo o país, mas sofrendo com a cooptação e o desrespeito a suas decisões (BALLAROTTI, 2012); com fortalecimento da atenção primária, mas também com o crescimento do setor privado (PAIM et al., 2011). O estado atual do direito à saúde no Brasil é, portanto, o produto dialético das disputas entre as pressões populares, por maior e melhor acesso a serviços (e mercadorias) de saúde, e as pressões das diferentes frações capitalistas, que buscam por maiores lucros no próprio setor saúde e também por parcelas cada vez maiores do orçamento do Estado.

Para melhor entender tanto as forças envolvidas na construção do direito à saúde, como também a situação da qual se parte para sua construção, faremos breve retrospectiva histórica da saúde no século $\mathrm{XX}$, dando destaque para algumas das políticas de saúde mais influentes, mas discutindo principalmente o movimento das classes. Para melhor realizar tal discussão, dividiremos o capítulo em duas seções: a primeira discutirá o período anterior a 1988 e a segunda seção discutirá o período que se segue à Constituição Federal de 1988. 


\subsection{Breve histórico da saúde pré-1988 30}

Para entender os avanços e fracassos na construção do Sistema Único de Saúde, não é possível olhar somente a partir de 1988, ou mesmo para as virtudes e defeitos do movimento da Reforma Sanitária Brasileira (RSB). É preciso resgatar brevemente algumas das características da assistência à saúde do período pré1988, principalmente no que se relaciona com o movimento das classes e com a acumulação capitalista.

\subsubsection{Da República Velha até o pré-1964}

A relação do Estado brasileiro com a saúde dos seus cidadãos nunca foi muito simples; basta que lembremos que algumas das primeiras intervenções relevantes do Estado nessa área, no início da república, acabaram por causar a Revolta da Vacina (1904), ainda hoje uma das maiores revoltas populares da história do país. Segundo Costa (1986), a nova configuração política e econômica que o Brasil assumia durante a Primeira República, com o fim do trabalho escravo e a hegemonia interna da burguesia cafeeira, ensejava também o desenvolvimento de uma política sanitária. Para Braga e Paula (1986):

"Do ponto de vista do atendimento à saúde, o primeiro destes aspectos parecia ter, como problema crucial, o saneamento dos portos e núcleos urbanos - como Rio, São Paulo e Santos - vinculados ao segmento comercial-financeiro do complexo exportador e ao capital industrial nascente. Tratava-se da criação de condições sanitárias mínimas indispensáveis não só às relações comerciais com o exterior, como também ao êxito da política de imigração, que pretendia atrair mão de obra fundamental para a constituição do mercado de trabalho capitalista" ( $p$. 46).

A capital, Rio de Janeiro, adquiria fama internacional de "pestilenta", afastando novos imigrantes, enquanto doenças infecciosas como varíola, febre amarela, peste bubônica e tuberculose assolavam as principais cidades brasileiras. As medidas que o Estado adota então são, em sua maioria, de cunho autoritário, como aquelas típicas da polícia sanitária, de inspiração alemã, e também como as urbanísticas, de inspiração francesa (COSTA, 1986). Braga e Paula (1986) apontam que algumas empresas maiores também adotavam iniciativas para "atrair e reter a mão de obra" (p. 47), como instituir creches, armazéns, moradia e assistência

30 Essa seção se baseia, em grande parte, nos trabalhos de Braga e Paula (1986) e Oliveira e Teixeira (1986). 
médica, ainda que, na maioria das vezes, esses serviços fossem cobrados dos próprios trabalhadores.

No final da década de 1910, uma série de fatores contribuiu para que a questão da saúde começasse a tomar ainda maior importância, como: o crescimento da organização política dos trabalhadores urbanos (Greve Geral de 1917), e o fortalecimento do movimento operário internacional (Revolução Russa); a grave crise social causada pela epidemia de Gripe Espanhola (1918), que dizimou parte da população e criou o caos nas cidades, com paralisação da economia, saques e grave crise de abastecimento; o engajamento dos principais intelectuais médicosanitários na Liga Pró-Saneamento, que defendia forte atuação do Estado na resolução dos problemas de saúde ${ }^{31}$. É nesse contexto que surge, em 1919, a lei de acidentes de trabalho e o Departamento Nacional de Saúde Pública (DNSP), e em 1923 é aprovada a lei Elói Chaves ${ }^{32}$ (COSTA, 1986). Para Braga e Paula (1986), no entanto, a questão mais importante que se coloca no período é a escassez relativa da mão de obra e necessidade de dar vazão à "violenta expansão da acumulação cafeeira que tem início em 1918" (p. 48).

Para Oliveira e Teixeira (1986), a lei Elói Chaves, que regulamenta as Caixas de Aposentadorias e Pensões (CAPs) das empresas ferroviárias, pode ser considerada o marco de início da previdência no Brasil. Para os autores, o modelo da década de 1920 pode ser definido por "uma relativa amplitude no plano de atribuições das instituições previdenciárias; uma prodigalidade nas despesas; e a natureza basicamente civil privada daquelas instituições" (OLIVEIRA; TEIXEIRA, 1986, p. 23)

Na década de 1920, as CAPs se limitam aos trabalhadores "vinculados ao setor urbano do complexo exportador" (BRAGA; PAULA, 1986, p. 49). É partir de 1930, no entanto, após a crise desse setor agrário exportador e com as

\footnotetext{
31 Já se encontrava ali um aspecto que permearia o debate da saúde pública nas décadas seguintes, que era a discussão da relação entre doença e pobreza. Durante a República Velha e o Estado Novo, dominava o discurso de que as condições sanitárias das cidades e as endemias do interior do país eram uma das principais causas do subdesenvolvimento econômico e da pobreza do país (COSTA, 1986; BRAGA; PAULA, 1986).

32 Eloi Chaves havia sido Secretário de Justiça em São Paulo durante a greve de 1917, que parou a cidade de São Paulo por um mês e obrigou o governo estadual a fugir da capital.
} 
consequentes mudanças políticas que se apresentam ${ }^{33}$, que há a ampliação da previdência para outros trabalhadores urbanos. Diferente do modelo da década de 1920, Oliveira e Teixeira chamam o modelo que se segue, de 1930 a 1945, de "contencionista". Se a legislação da década de 1920 estipulava como responsabilidade das caixas de pensão tanto aspectos previdenciários (aposentadorias e pensões) como também assistenciais (assistência médica e farmacêutica) de forma ampla, a partir da década de 1930, ambos aspectos passam a ser restringidos. Já em 1931 é aprovada lei que restringe os gastos em assistência nas CAPs para até $8 \%$ da receita anual total. Na criação dos Institutos de Aposentadorias e Pensões (IAPs) a partir de 1933, essa orientação restritiva se aplica não somente à assistência ${ }^{34}$, mas também ao aspecto previdenciário, com o aumento da idade mínima de aposentadoria, ou até mesmo a exclusão da possibilidade de aposentadoria por idade, restando nesse caso somente a aposentadoria por invalidez.

Associadas a maiores pagamentos por parte dos trabalhadores, as restrições nas despesas previdenciárias tiveram efeito importante. Se na década de 1920 os gastos totais alcançavam até $65 \%$ das receitas, a partir da década de 1930 alcançavam somente cerca de $30 \%$, ou seja, passavam a ter até $70 \%$ de superávit (OLIVEIRA; TEIXEIRA, 1986, p. 58).

Ao se considerar o momento político, tais medidas restritivas não poderiam ser implementadas sem conflito. Se por um lado o governo era pressionado, inclusive por credores externos, pela queda na arrecadação e pelo aumento dos gastos decorrentes da "necessidade" de bancar a sobrevivência do setor agrário exportador, afetado pela crise econômica do início da década de 1930, por outro lado havia também resistência dos trabalhadores - algumas greves foram realizadas entre 1932 e 1935 com o objetivo de combater as medidas contencionistas dirigidas

${ }^{33}$ Com a crise nos países centrais a partir de 1929, há relativo enfraquecimento das oligarquias regionais, como a cafeeira de São Paulo, e a ascensão de Vargas com base em uma aliança mais heterogênea. Tudo isso associado à crescente industrialização dá lugar a um quadro político, ao menos provisoriamente, mais instável e aberto às reivindicações dos trabalhadores.

${ }^{34} \mathrm{Em}$ alguns casos, como na criação do IAPI (1936), o IAP dos industriários, o decreto garante apenas $\mathrm{O}$ aspecto previdenciário, de aposentadorias e pensões, sendo 0 aspecto assistencial colocado somente como possibilidade futura, a ser (ou não) implementada, e ainda assim, podendo estar sujeitos a "contribuição suplementar". Somente em 1950, após pressão da categoria e do governo federal, o IAPI passa a cumprir funções de assistência à saúde (OLIVEIRA; TEIXEIRA, 1986). 
à previdência. A partir de 1935, no entanto, ainda antes do início do Estado Novo (1937), medidas autoritárias do Governo Vargas, como a prisão de líderes sindicais, enfraqueceram o movimento trabalhista e dificultaram a organização de novas greves (OLIVEIRA; TEIXEIRA, 1986, p. 108-9).

Ao se seguir essa lógica contencionista, uma proporção maior dos cuidados médicos passou a ser comprada pelos IAPs junto a terceiros, em vez do estabelecimento de serviços próprios como era comum na década de 1920. Aqui, os prestadores de serviço eram geralmente clínicas ou hospitais de pequeno porte, diferente do que passa a ser visto a partir do final da década de 1960, em que instituições médicas privadas de maior porte, com caráter empresarial, "se elevam à condição de forte bloco de influência sobre a própria Previdência Social" (OLIVEIRA; TEIXEIRA, 1986, p. 92).

Outra mudança relevante implementada com a fundação dos IAPs era a maior participação do Estado. Diferente das CAPs, que tinham caráter civil e privado, algumas das IAPs eram diretamente subordinadas ao Ministério do Trabalho, Indústria e Comércio (MTIC) e tinham seu diretor geral indicado diretamente pelo Presidente da República. Essa maior participação do Estado é particularmente importante, pois expressa uma mudança em relação à política mais liberal que o Estado brasileiro adotava em relação ao trabalho na era pré-Vargas.

Lima, Fonseca e Hochman (2005) apontam como a política para a saúde do Estado Novo "marcaria definitivamente as ações de saúde no Brasil" (p. 43). Essa política podia ser dividida em dois aspectos: de um lado a assistência médica individual previdenciária submetida ao MTIC, para os trabalhadores formais dos setores mais dinâmicos da economia; do outro as ações de saúde coordenadas pelo Ministério da Educação e Saúde (MES), que abrangia principalmente campanhas e ações orientadas ao enfrentamento de endemias e doenças infecto-contagiosas, com a institucionalização de um modelo verticalizado, centralizado e segmentado ${ }^{35}$ (LIMA; FONSECA; HOCHMAN, 2005).

${ }^{35}$ Submetido ao MES, havia o Departamento Nacional de Saúde (DNS), que segmentava suas ações em serviços de saúde voltados a doenças específicas (febre amarela, malária, câncer, tuberculose, lepra e doenças mentais). 
No que se refere ao orçamento do Estado, portanto, era possível dividir os gastos em saúde entre: os gastos diretos, realizados principalmente através das campanhas voltadas ao combate de doenças específicas e endemias rurais; e o indireto, que se realizava através do financiamento da previdência. Se nas CAPs o financiamento era realizado diretamente por trabalhadores e empregadores, a partir da criação dos IAPs, o Estado passava também a "contribuir" para as receitas previdenciárias. O governo passou a centralizar o recolhimento de "quotas" sob os produtos comercializados pelas próprias empresas envolvidas no sistema previdenciário e também a cobrar taxas sob produtos importados ${ }^{36}$. Ao contrário das ações submetidas ao MES, essa "participação do Estado" no financiamento da previdência não representou, até 1945, grandes despesas para a União, mas ao contrário, acabava por criar uma nova fonte de receitas. Apesar de constar em lei que as contribuições seriam paritárias - ou seja, que as contribuições dos trabalhadores, empregadores e do Estado seriam iguais - na prática, o Estado nunca respeitava os prazos ou os valores devidos (OLIVEIRA; TEIXEIRA, 1986) ${ }^{37}$.

Além de aproveitar para outros projetos os recursos captados para a previdência, o $1^{\circ}$ Governo Vargas também utilizava os fundos dos Institutos para investimentos diversos. A opção de organizar a previdência através de um "regime de capitalização" ditava que o superávit dos fundos fossem investidos de modo a autofinanciar o sistema. Isso era feito principalmente através da compra de títulos da dívida pública e ações de empresas estatais, de modo que, em 1937, a proporção dos fundos das Instituições da Previdência que estavam investidos em papéis da dívida pública alcançava 85,2\% (OLIVEIRA; TEIXEIRA, 1986).

"Dessa maneira, dado o grande montante de recursos mobilizados e o tamanho de suas reservas investidas, a Previdência Social foi se transformando, aos poucos, num dos mais importantes "sócios" da União e das empresas semi-estatais que Vargas fez nascer. Em outras palavras, a Previdência tornou-se um importante mecanismo de acumulação financeira em mãos do Estado, graças ao "regime de capitalização"' (OLIVEIRA; TEIXEIRA, 1986, p. 142).

\footnotetext{
${ }^{36}$ Mais detalhes em (Im)previdência social: 60 anos de história da Previdência no Brasil (OLIVEIRA; TEIXEIRA, 1986, p. 100-7).

37 Após o crescimento dos gastos da previdência no período de 1945 a 1960, e com vultuoso crescimento da dívida da União para com a previdência, a contribuição do Estado deixa de ser paritária, institucionalizando-se o que já acontecia de fato; os principais responsáveis pelo financiamento da previdência no Brasil eram os próprios segurados.
} 
Para os autores, mesmo que no início da década de 1930 a orientação contencionista pudesse ser somente uma estratégia para lidar com a crise fiscal ${ }^{38}$, a partir da metade da década, quando a situação econômica do país já voltara à normalidade, tais medidas foram mantidas, e até mesmo aprofundadas - sempre com indefectíveis argumentos técnicos ${ }^{39}$ - com o objetivo de garantir uma fonte de receitas extra à União, que seria utilizada para financiar projetos estratégicos de industrialização e também na área agrícola. Ou seja, já na década de 1930, nos primeiros anos da previdência social no Brasil, estava dada a contenda entre os direitos previdenciários - e nesse caso significativamente a assistência à saúde - e a acumulação capitalista, com o segundo se apoderando dos recursos do primeiro.

A partir de 1945, novas mudanças na conjuntura nacional ${ }^{40}$ e internacional ${ }^{41}$ foram acompanhadas também por mudanças na situação da previdência brasileira. Há ampliação progressiva do acesso dos segurados a benefícios previdenciários e também à assistência à saúde ${ }^{42}$. Essa tendência se inicia em 1945, ainda nos últimos meses do governo Vargas e, de maneira geral, se mantém nos governos seguintes, até a aprovação em 1960 da Lei Orgânica da Previdência Social (LOPS), que uniformizava "por cima"43 o acesso dos segurados de todos os institutos. Segundo Oliveira e Teixeira:

"A legislação previdenciária do pós-45 é marcada, em linhas gerais, pela progressiva desmontagem das medidas de cunho contencionista impostas

\footnotetext{
${ }^{38}$ Não se pode esquecer que essa crise fiscal foi aprofundada pela necessidade de bancar o setor agrário exportador.

${ }^{39}$ Ao analisar o papel das formulações técnicas acerca da "inevitabilidade" das medidas restritivas, Oliveira e Teixeira anotam: "Os "tecnocratas", "intelectuais", ou "cardeais" da Previdência desempenharam, assim a nosso ver, uma função político-ideológica muito clara: utilizando-se do fetiche da técnica e das referências internacionais, dar consistência à defesa de uma atitude contencionista, já decidida e estabelecida previamente por natureza político-econômica" (OLIVEIRA; TEIXEIRA, 1986, p. 114).

40 Trata-se da abertura política, com maior organização dos trabalhadores urbanos e a necessidade dos novos governos de angariar maior apoio das camadas populares.

${ }^{41}$ Houve no pós-guerra, principalmente na Europa ocidental, uma preocupação maior em fazer os governos enfrentarem o tipo de problema social que poderia dar margem ao crescimento do movimento comunista ou a repetir experiências como o fascismo. Esse tipo de preocupação, assim como o próprio fortalecimento político dos trabalhadores, permitiu que esses países adotassem políticas que viriam a ser conhecidas como políticas do "Welfare State (WS)", ou políticas do Estado de Bem Estar Social. Admite-se que a criação dos WSs também foi produto da pressão da classe trabalhadora ao capital, por maiores condições sociais. Para essa abordagem, ver Behring e Boschetti (2006), cap.3.

42 Apesar de cobrir uma proporção relativamente pequena da população brasileira na época, a assistência à saúde ligada aos IAPs representava parcela importante da assistência à saúde no Brasil (OLIVEIRA; TEIXEIRA, 1986).

${ }^{43}$ Uniformizava as regras para concessão de benefícios tendo como base as coberturas mais amplas, como as do IAPB.
} 
no período anterior. [...] Isto não se faz de uma só vez, desenvolvendo-se, ao contrário, até 1960 (promulgação da LOPS) de forma gradual, através de copiosa legislação, que assume um caráter puntiforme e casuístico. Instituto por Instituto e área por área de atividade da Previdência vão sendo contemplados sucessivamente, como veremos, por pequenas medidas que: ora ampliam os planos de benefícios ou de serviços de uma dada instituição, ora permitem a elevação dos gastos com os últimos ou facilitam 0 acesso dos segurados ou seus dependentes a eles, ora facilitam a concessão ou majoram os valores dos benefícios pecuniários, etc. Desenhando-se assim um processo que é bastante expressivo do contexto democrático-populista agora subjacente (enquanto aparentemente pautado pela tendência às respostas circunstanciais e localizadas a pressões e interesses de pequenos grupos)" (OLIVEIRA; TEIXEIRA, 1986, p. 154).

Apesar da ampliação na cobertura, com o consequente aumento nas despesas, o Estado e os empregadores continuaram a pagar consideravelmente menos do que a sua devida contribuição paritária, ou seja, o custo da previdência era pago, em grande parte, pelos próprios segurados. Em 1956, por exemplo, o Estado efetuou o pagamento de somente $15 \%$ da sua parte devida, enquanto as empresas pagaram somente cerca de 65\%. O aumento da cobertura sem a resolução desses problemas de arrecadação causou o que muitos chamam de "Crise da Previdência" (OLIVEIRA; TEIXEIRA, 1986).

O avanço tecnológico e mudanças no setor saúde experimentados no pósGuerra se traduzem no Brasil, a partir do final da década de 1950, em uma mudança no perfil assistencial, com importante crescimento do cuidado hospitalar, maior especialização, e acelerada incorporação de novas tecnologias e equipamentos. Tudo isso resulta em maiores custos para a assistência médica. Braga e Paula (1986) apontam esse momento como determinante para a articulação do setor saúde com a acumulação capitalista, pois além de estabelecer novos patamares de gastos em medicamentos, equipamentos e insumos, apresentou também importante crescimento, tanto em número como em importância, dos prestadores de serviço voltados para o lucro, em detrimento dos prestadores filantrópicos.

No que se refere à "Saúde Pública" propriamente dita, ou seja, aquela submetida ao MES, não houve mudanças tão significativas no período de abertura democrática pós-1945. Apesar do surgimento de maior amplitude no debate da 
saúde pública ${ }^{44}$, da criação do Ministério da Saúde em 1953, e da forte vocação assistencial posta em prática pelo Serviço Especial de Saúde Pública (SESP) ${ }^{45}$ no interior do Brasil, manteve-se, no geral, orientação semelhante na organização das ações de saúde; campanhas e programas verticalizados e segmentados ocupando o papel central, com discreta atuação assistencial.

\subsection{2 - O período da Ditadura Militar e a saúde ${ }^{46}$}

Em um momento de acirramento de tensões entre os setores nacionaldesenvolvimentistas (mais próximos aos trabalhadores organizados) e as classes proprietárias mais alinhadas aos interesses externos (e apoiadas pelas classes médias mais conservadoras), os militares (sob os auspícios do imperialismo) intervieram em favor dos últimos para garantir que a reprodução capitalista se realizasse sem sobressaltos - disciplinando os trabalhadores a qualquer custo e maximizando as condições para a obtenção de lucros. As repercussões desse projeto na saúde, e algumas características chave do período serão discutidas a seguir.

A primeira característica do período a ser abordada é a queda relativa que sofreram, a partir de 1964, os investimentos estatais nas áreas sociais, em favor de investimentos na infraestrutura econômica. De 1968 a 1974, a participação das políticas sociais no orçamento da união (previdência, saúde, educação e saneamento) diminuíram de $24,7 \%$ para $20,7 \%$, já os gastos da rubrica "Saúde e Saneamento" reduziram de 4,6\% para 2,5\% (OLIVEIRA, 1985 apud CARDOSO, 2013 $)^{47}$. Somando-se isso à deterioração do poder de compra da população de baixa renda, observou-se no período uma piora nas condições de saúde da população:

${ }^{44}$ Surgem diferentes posições na discussão da relação entre doença e desenvolvimento, enquanto tecem-se também críticas à centralização e segmentação vigentes nas políticas federais. Mais em Lima, Fonseca e Hochman (2005).

${ }^{45}$ A SESP foi criada ainda durante a Segunda Guerra, num esforço conjunto com os EUA e tinha, a princípio, financiamento externo e autonomia institucional. Tinha o intuito de garantir aos Aliados o abastecimento de matérias primas fundamentais ao esforço de guerra, como o minério de ferro e a borracha, atuando inicialmente, portanto, nas bacias do Rio Doce e do Rio Amazonas. Após a Guerra, manteve-se com financiamento do governo brasileiro, mas ainda com relativa autonomia Mais em (BRAGA; PAULA, 1986) e (LIMA; FONSECA; HOCHMAN, 2005).

${ }^{46}$ Essa seção retira muitos de seus elementos do trabalho de Cardoso (2013).

47 Diversos autores (OLIVEIRA; TEIXEIRA, 1986; BRAGA; PAULA, 1986; CARDOSO, 2013) ressaltam a dificuldade de padronizar os dados do orçamento desses anos, de maneira que os diferentes estudos podem apresentar números absolutos diferentes entre si. Ainda assim, todos apontam a mesma tendência de importante desfinanciamento das áreas sociais. 
"Com efeito, chega-se a 1973 com um quadro de saúde pública muito grave, configurado pela conjunção de enfermidades crônico-degenerativas ao lado das infecto-contagiosas; pela ocorrência nos centros urbanos de endemias antes apenas rurais, como a doença de Chagas etc.; pelo retorno da tuberculose como enfermidade significativa nacionalmente; pela vigência da desnutrição e de altas taxas de mortalidade infantil" (BRAGA; PAULA, 1986, p. 93).

Uma segunda característica importante do período foi a maior relevância que tomaria a assistência médica submetida à Previdência, se comparada aos investimentos diretos realizados em saúde. Ou seja, não somente os gastos sociais seriam menores, como mudaria também o modo de realizá-los. Se os investimentos em projetos de caráter coletivo e de prevenção, (tipicamente não lucrativas e, em todo lugar, assumidas pelo Estado) foram mantidos no mínimo possível, o acesso dos trabalhadores à previdência e a seus serviços foi progressivamente ampliado ${ }^{48}$. A Previdência foi submetida a uma estratégia de agressiva ampliação da base segurada, tanto na tentativa de ampliar a arrecadação (BAHIA, 2005), como também devido à necessidade do novo regime de angariar apoio e legitimação social (OLIVEIRA; TEIXEIRA, 1986). Essa expansão passou a ocorrer já em 1964, ainda antes da criação do Instituto Nacional de Previdência Social (INPS), e seria reforçada pela posterior inclusão previdenciária das empregadas domésticas (1972) e dos trabalhadores autônomos (1973), sem falar na criação do PRORURAL em 1971, com a efetiva extensão dos benefícios previdenciários aos trabalhadores rurais (OLIVEIRA; TEIXEIRA, 1986; BAHIA, 2005) ${ }^{49}$. Diferente da ditadura do Estado Novo, portanto, quando foi adotada orientação contencionista na concessão de benefícios, a Ditadura de 1964 manteve a ampliação de coberturas do período democrático e ainda utilizou a ampliação da base previdenciária como estratégia para ampliar o acesso à assistência à saúde (BAHIA, 2005). E mesmo que a capacidade instalada da assistência médica previdenciária não fosse ampliada na mesma proporção do crescimento da base segurada (CORDEIRO, 1984, p. 123), a mudança de prioridades era clara: enquanto o gasto direto em saúde (Ministério da Saúde) alcançava em 1975 somente $77 \%$ do gasto indireto (INPS e FUNRURAL),

48 Alguns autores (BRAGA; PAULA, 1986; OLIVEIRA; TEIXEIRA, 1986) apontam como essa mudança indicava um maior foco numa medicina individual, curativa, em detrimento de uma abordagem populacional mais ampla, com aspectos preventivos.

${ }^{49}$ Bahia (2005) aponta que: "Entre 1968 e 1978, o número de segurados contribuintes praticamente triplicou (de 7.763.058 de contribuintes para 21.166.088). Em meados desta década, os benefícios da previdência atingiam aproximadamente $78 \%$ da população urbana" (p. 427-8). 
anteriormente, em 1967, essa proporção era de 127\% (BRAGA; PAULA, 1986, p. 99).

Apesar disso, a participação da União no financiamento do INPS era relativamente pequena ${ }^{50}$; somava somente $9,2 \%$ das receitas da previdência em 1967 e diminuiria ainda mais, chegando a 4,7\% em 1976 (BRAGA; PAULA, 1986, p. 107). A contribuição dos empresários já não podia mais ser retardada, como antes, mas era, na maioria das vezes, repassada aos preços aos consumidores. O financiamento da previdência e de sua assistência médica era garantido, portanto, quase que exclusivamente, pelos próprios trabalhadores segurados e pelos consumidores.

A terceira característica do período a ser ressaltada é a importante centralização política e burocrática a que foi submetida a Previdência Social. Mesmo que nunca tenha sido o seu principal financiador - pelo contrário - era fundamental para o Estado manter o seu controle ${ }^{51}$. O modo de exercer esse controle, evidentemente, nem sempre era o mesmo. Se o período democrático de 1945 a 1964 havia sido marcado pela ampliação da capacidade de intervenção política dos trabalhadores, o regime de 1964 tinha como princípio basilar realizar justamente o oposto. A unificação dos IAPs na criação do INPS, em 1967, seria passo importante para facilitar o comando político, burocrático e financeiro do aparelho previdenciário. Apesar de a proposta de unificação dos IAPs ser anterior ao governo dos militares, a maneira como foi realizada, garantiria um rígido controle por parte do governo, tanto por meio do definitivo afastamento dos trabalhadores da gestão previdenciária, como também por meio do empoderamento de quadros técnico-burocráticos que tinham uma visão mais alinhada àquela do novo regime, como os chamados "cardeais" do Instituto de Aposentadorias e Pensões dos Industriários (IAPI) ${ }^{52}$ (CARDOSO, 2013).

\footnotetext{
50 A essa altura, a contribuição do Estado deveria cobrir somente os custos de administração da Previdência, mas o valor repassado era sempre consideravelmente menor que o necessário. Ver mais detalhes em Oliveira, Beltrão e David, 1999.

51 Assim como aconteceu no Estado Novo, a centralização dos fundos previdenciários serviu para que o governo federal financiasse grandes obras de infraestrutura e fomentasse a acumulação capitalista (FAGNANI, 1997).

52 O IAPI foi o último Instituto a garantir assistência à saúde (somente na década de 1950 e mesmo assim sob grande pressão do governo federal) e quando o fizeram, no sentido de evitar maiores investimentos, o faziam quase que exclusivamente a partir da contratação de serviços não-próprios (OLIVEIRA; TEIXEIRA, 1986).
} 
A quarta característica que merece destaque é a mudança na relação da Previdência Social com o setor privado. No período que vai de 1945 a 1964, houve importante expansão da rede própria dos $\operatorname{IAPs}^{53}$. Apesar dessa expansão não ter sido suficiente para fazer com que os serviços contratados deixassem de ser responsáveis pela maior parte da assistência, eles passaram a ser encarados, na maioria dos Institutos, como provisórios ou complementares (OLIVEIRA; TEIXEIRA, 1986). No período pós-1964, por outro lado, com os "argumentos técnicos" de sempre, da insuficiência da rede própria e da necessidade de reduzir custos (Idem) e assim como no período autoritário anterior, a expansão da assistência médica se daria prioritariamente através da contratação de serviços privados ${ }^{54} 55$.

Essa preferência pela contratação de serviços privados, no entanto, refletia uma escolha política por parte do regime e a maior influência de alguns setores.

"O afastamento das entidades sindicais dos trabalhadores das decisões sobre os rumos das políticas previdenciárias deu lugar às relações diretas da Previdência com prestadores de serviços e produtores de insumos. As pautas de debate e negociação sobre assistência foram fortemente influenciadas pelas entidades médicas e, mais tarde, pelas de representação dos empresários hospitalares e de empresas de planos de saúde" (BAHIA, 2005, p. 426).

Como aponta Cardoso (2013), as divergências de projeto entre as entidades médicas - que defendiam aspectos mais tradicionais do trabalho médico - e aquelas representantes dos prestadores de serviço - que defendiam um modelo mais empresarial, voltado para o lucro - não foram grandes o bastante para frear a plena integração dos serviços de saúde à reprodução capitalista. Ao contrário, a influência

\footnotetext{
53 Segundo Oliveira e Teixeira (1986):

“... não possuímos a informação exata sobre o número de hospitais existentes anteriormente ao inicio deste nosso período (1945). Mas se pode afirmar que, até 1948, não existiam mais do que 4 ou 5 hospitais próprios dos IAPs. Em 1950 eles somam 9, em 1966 (ano de criação do INPS) serão 28 e, em 1978, 32. O que faz com que se possa caracterizar o período que vai de 1945 à unificação dos institutos em 1966 como correspondendo a um verdadeiro "boom" de expansão do setor próprio da assistência médica previdenciária, tendo surgido aí pelo menos $3 / 4$ dos atuais hospitais de nossa Previdência Social. [...] A prática de comprar serviços médicos e hospitalares a terceiros era, além disso, mantida. Agora, contudo, ao contrário do que ocorria no período anterior, essa atitude era definida como meramente provisória [...] (OLIVEIRA; TEIXEIRA, 1986, p. 184-5)

${ }^{54}$ Bahia (2005) aponta como o modelo de assistência médica instituído pela LOPS (1960) já daria as bases para a privatização e segmentação características da assistência à saúde na ditadura, enquanto Cardoso (2013) demonstra como essas características são ainda mais estimuladas a partir de 1964.

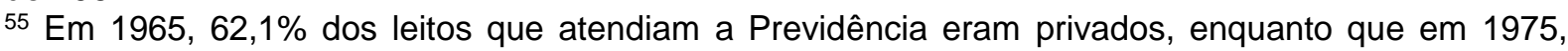
essa proporção aumentou para $68,4 \%$. Mais significativo, no entanto, é o aumento na proporção de leitos em instituições voltadas para o lucro - dentre as instituições privadas, eles alcançavam somente 14,4\%, em 1960, enquanto que em 1975, essa proporção era de 45,2\% (BRAGA; PAULA, 1986, p. 75).
} 
desses setores sobre a Previdência Social e o Estado brasileiro confluiu para a criação de um perfil assistencial que agradava a ambos, permitindo às empresas (de serviços e também industriais) uma operação bastante lucrativa ${ }^{56}$, ao mesmo tempo em que mantinha boa parte da autonomia defendida pelas associações médicas.

Os impactos desse modelo na formação da rede assistencial foram profundos, distorcendo a expansão da rede não somente em direção à criação de serviços voltados para a maximização das receitas ${ }^{57}$, assumindo somente as internações e procedimentos mais lucrativos (deixando as atividades mais custosas para a rede própria da Previdência ou outras modalidades não-lucrativas), mas também causando importantes disparidades regionais, com grande concentração de serviços de saúde nas regiões urbanas mais industrializadas das regiões Sul e Sudeste, mantendo praticamente desassistidas largas regiões do Norte e Nordeste.

A lucratividade e o crescimento vultoso do setor de serviços médicos nesse período não foram garantidos somente pela grande ampliação da cobertura e pelo modo de contratação do INPS, mas também pelo incentivo concedido em forma de empréstimos generosos ${ }^{58}$ e renúncias fiscais.

A quinta e ultima característica que gostaríamos de ressaltar aqui, e que, de certa forma, é consequência daquelas citadas anteriormente, é o aprofundamento da segmentação ou estratificação da assistência à saúde que se observa no período.

Aqui nos referimos a dois processos: a diferenciação do acesso com base na clientela, com o estabelecimento de arranjos assistenciais distintos para diferentes categorias; e também com base nas diferentes enfermidades, com os serviços públicos assumindo os cuidados mais dispendiosos e menos propensos a gerar lucros.

A diferenciação mais óbvia era aquela entre os segurados pela Previdência, em sua maioria trabalhadores inseridos formalmente no mercado de trabalho, e

\footnotetext{
56 Para mais detalhes, ver Braga e Paula (1986).

57 Um dos mais célebres críticos dessa situação era Carlos Gentile de Mello, que dizia que o modo de pagamento do setor contratado da Previdência, por Unidades de Serviço (US), era fator incontrolável de corrupção. Em uma entrevista ao jornal O Globo comparou: "Seria a mesma coisa que pagar bombeiros por número de incêndios debelados, o que poderíamos chamar então de unidades de labareda" (MOROSINI, 2013, p. 31).

58 Um exemplo aqui é a utilização de recursos do Fundo de Apoio ao Desenvolvimento Social (FAS) na construção de clínicas e hospitais privados (BRAGA; PAULA, 1986; OLIVEIRA; TEIXEIRA, 1986).
} 
aqueles não segurados, que ficavam a mercê de entidades beneficentes e dos parcos serviços públicos. Havia, no entanto, formas de diferenciação mesmo no interior da Previdência, e uma das principais maneiras pelas quais isso se dava era através do estabelecimento de convênios com o INPS, numa modalidade na qual havia o pré-pagamento pelo cuidado global de cada segurado, em vez da contratação por procedimento. Os convênios poderiam ser firmados com sindicatos, universidades, governos estaduais e municipais, mas foram, em sua maioria, firmados com as empresas empregadoras ${ }^{59}$.

Nessa modalidade de convênio, a empresa empregadora, mediante a restituição de parte de sua contribuição, provia atendimento médico a seus trabalhadores, geralmente através da contratação de uma empresa médica (chamada de medicina de grupo). Muitas vezes essa empresa médica passaria a cumprir o papel anteriormente cumprido pelo "departamento médico" da empresa empregadora ${ }^{60}$. Com as regulamentações que foram aprovadas ao longo do tempo, aumentando os subsídios fiscais ${ }^{61} \mathrm{e}$ ampliando as atribuições previdenciárias dessas empresas ${ }^{62}$, essa modalidade de serviço acabou sendo uma maneira de diferenciar 0 acesso de certas categorias ${ }^{63}$, provendo-Ihes uma assistência de

59 Essa modalidade de convênio não foi criada pela Ditadura Militar; o IAPI já havia realizado anteriormente convênios com empresas. A LOPS, de 1960, já autorizava os convênios que viriam a ser realizados com as empresas empregadoras e com a medicina de grupo. O primeiro convênio desse tipo só foi realizado, no entanto, em maio de 1964, com a Volkswagen (CARDOSO, 2013).

60 Como descrevem Oliveira e Teixeira, um dos aspectos que essas empresas assumiam era a seleção da mão de obra: "A complementaridade começa pela seleção de pessoal (um dos aspectos que apontamos anteriormente como de interesse da empresa). As empresas médicas contratadas ficam encarregadas também desta tarefa, antes atribuída aos departamentos médicos. Ocorre que, como o sistema vigente é o pré-pagamento a valores fixos por empregado, interessa também aos "grupos médicos" a seleção mais acurada possível do pessoal a ser contratado pela empresa compradora, de modo a procurar reduzir ao máximo os atos médicos futuramente necessários" (OLIVEIRA; TEIXEIRA, 1986, p. 225).

${ }^{61}$ Bahia descreve a situação: "A Previdência Social contribuía com cerca de $30 \%$ do total do valor dos planos e o restante era absorvido como custo operacional a ser deduzido do pagamento de impostos, inclusive do Imposto de Renda, a partir de 1974, e pagos pelo consumo de toda a sociedade" (BAHIA, 2005, p. 430)

62 Bahia descreve: "A partir de 1972, o INPS autorizou a expedição de atestados para justificar falta por motivo de doença pelos serviços médicos das empresas. [...] Em 1974, a Previdência Social, no âmbito do Plano de Pronta Ação, estendeu as atribuições dos convênios. O abono dos dias não trabalhados passou a ser uma atribuição exclusiva das empresas de planos de saúde ou dos serviços médicos das empresas empregadoras. Além disso, os empregados e seus dependentes cobertos pelos convênios tiveram suas carteiras de trabalho anotadas para evitar que os mesmos utilizassem serviços da rede própria da Previdência Social" (BAHIA, 2005, p. 428-9).

63 Oliveira e Teixeira demonstram como essa diferenciação ocorria dentro de um mesmo contrato: "Como exemplo, podemos tomar a 'Interclinicas', uma empresa de medicina de grupo que oferece as seguintes faixas diferenciadas de atenção dentro de um mesmo contrato: 'Standard, Extra, Especial e Executivo" (OLIVEIRA; TEIXEIRA, 1986, p. 227). 
melhor qualidade (e mais cara ${ }^{64}$ ) do que aquela provida pelos serviços próprios e contratados da Previdência, mas com os custos socializados através de restituições e renúncias fiscais.

Como ressalta Bahia (2005), a modalidade de convênios não chegou a ser importante pela quantidade de segurados que cobria ${ }^{65}$, mas sim pelo estabelecimento das regras e padrões que viriam a moldar as relações entre Estado e o setor privado até hoje.

"Tal legislação estabeleceu os pilares para a expansão dos planos de saúde. A divisão dos riscos entre o público e o privado - deixando para o primeiro, além dos idosos, os portadores de sequelas exigentes de reabilitação, pacientes de longa permanência e casos de tuberculose, doença mental, implantes, transplantes, cirurgia cardiovascular, hemodiálise e microcirurgias - e a ampla margem de decisão das empresas empregadoras sobre a amplitude das coberturas e elegibilidade dos dependentes dos empregados conformam os dois principais vetores que dinamizaram o mercado de planos de saúde nas décadas de 1970 e 1980" (BAHIA, 2005, p. 429-30).

O modelo de privilegiar a contratação de serviços privados mostrou-se, por fim, caro e ineficiente mostrando que, longe de política social de redistribuição, a Previdência Social consistiu em poupança compulsória e garantia de recursos inesgotáveis para a vultosa expansão dos negócios no setor saúde, tanto do seu complexo industrial como de suas empresas de serviço. Ao analisar o período, Cardoso (2013) fala sobre a "institucionalização da lógica dos negócios".

Por fim, o modelo de acesso a serviços de saúde construído pela Ditadura Militar pode ser resumido nos seguintes pontos: a diminuição dos investimentos nas áreas sociais e na saúde pública, causando piora na qualidade de vida e na saúde da população; a ampliação do acesso à Previdência Social como principal estratégia de garantir acesso à saúde; a centralização politica e institucional da Previdência como forma de garantir acesso privilegiado aos fundos previdenciários e também de anular a participação e influência dos trabalhadores; a posição privilegiada do setor privado tanto na determinação de políticas como também no estabelecimento de contratos; o aprofundamento da segmentação do acesso à

\footnotetext{
${ }^{64}$ Novamente, de acordo com Bahia: "Em 1978, os gastos com planos de saúde oscilavam entre três a dez vezes mais do que as despesas com os demais segurados e beneficiários" (BAHIA, 2005, p. 430).

65 Segundo Bahia (2005, p. 428), essa cobertura jamais ultrapassou $10 \%$ dos segurados pela Previdência Social.
} 
assistência médica, consolidando um padrão de acesso a serviços de saúde que discrimina a utilização de recursos com base na posição econômica e social de cada indivíduo, e não de acordo com suas necessidades de saúde.

Esse regime autocrático, antissocial e tomado pela "lógica dos negócios" havia construído um sistema de saúde à sua imagem. Além do enorme custo humano e social, esse modelo permitiu a articulação definitiva do setor saúde à reprodução do capital, garantindo a implementação de um padrão assistencial que além de majorar o consumo de medicamentos, insumos e equipamentos, passou a ser quase que completamente executado por uma rede privada.

\subsubsection{Crise da Ditadura e Reforma Sanitária ${ }^{66}$}

Aos poucos foi ficando clara a incapacidade do regime militar em conduzir o Estado brasileiro. Com o declínio do "milagre econômico brasileiro"67 a partir da metade da década de 1970, começaram a escassear tanto o consentimento passivo dos despossuídos como também o apoio ativo das classes proprietárias. Ainda que a ditadura mantivesse uma postura absolutamente autoritária, exemplificada por, dentre outros, o assassinato de Vladimir Herzog, em outubro de 1975, foi forçada a buscar outras formas de controle. Nesse contexto, alguns grupos de orientação crítica e de resistência à ditadura passam a se rearticular ${ }^{68}$. Na saúde, essa

66 Diversos autores debruçaram-se sobre a Reforma Sanitária Brasileira (RSB), apontando suas virtudes, fraquezas, acertos e descaminhos, ver principalmente Dantas (2014), Oliveira (1987), Teixeira (1987). Leituras que ajudam a entender o passado, o presente e o futuro da difícil tarefa de construir, não só um sistema de saúde, mas direitos sociais no Brasil. Justamente pela riqueza e ampla disponibilidade dessas análises, aqui nos limitaremos a apontar algumas características gerais do processo, em especial o que concerne ao movimento das classes. Dentre as fontes pesquisadas, destacam-se os trabalho de Paim (2008) e Faleiros et al (2006).

67 O "milagre econômico" no Brasil foi um período de forte crescimento do PIB e da produção industrial entre 1968 a 1973. Na realidade, a economia brasileira beneficiou-se do grande crescimento do comércio mundial e dos fluxos financeiros internacionais para crescer sua abertura comercial e financeira em relação ao exterior. Nesse ciclo de expansão, predominaram os setores produtores de bens duráveis e de bens de capital, de um lado, e de outro, a intensa participação de capital estrangeiro, sob a forma de investimentos diretos. Para o entendimento sobre esse período, ver Marques e Rego (2013), cap. 9.

68 Sobre isso escreve Saes (2001): "Todavia, a ditadura militar [...] não liquida todos os mecanismos estatais de corporativização das classes assalariadas. Durante pelo menos uma década, os mecanismos subsistentes - o sindicalismo de Estado expurgado das "organizações paralelas", a justiça do trabalho diminuída na sua capacidade decisória - são encobertos pelo exercício de repressão; e sua eficácia ideológica parece estar "adormecida". [...] A crise política de meados dos anos 70 evidenciará que esses mecanismos ainda se encontram em operação efetiva. A incompatibilidade crescente de certas frações de classe dominante com a orientação geral da política de Estado obriga as equipes governamentais a tomar atitudes mais moderadas no terreno das relações com as classes trabalhadoras. Protegido indiretamente pelo escudo da dissidência (larvar) burguesa, o movimento reivindicatório popular das regiões industrialmente mais avançadas parece 
rearticulação pode ser exemplificada pela criação do Centro Brasileiro de Estudos de Saúde (Cebes), em julho de 1976.

A crise que enfrentava o regime militar tinha tanto seu componente econômico e fiscal como também o político, de legitimação do Estado69. A crise econômica de meados da década de 1970, melhor abordada no Capítulo 1 desse trabalho, teria repercussões importantes também na situação do orçamento do Estado, que passaria a ser disputado mais aguerridamente pelas frações capitalistas (com destaque, a partir daquele momento, para o poder que adquiririam as frações associadas ao capital portador de juros). Nessa situação, era insustentável que se mantivesse a destacada prodigalidade em favor dos setores de bens e serviços em saúde, que caracterizava o sistema de saúde de então. A crise política, por outro lado, poderia ser considerada, em parte, derivada da crise econômica, devido ao achatamento dos salários e piora das condições de vida que ensejaria, mas também deve ser considerada produto do sub-investimento crônico em politicas sociais, como educação, saúde e saneamento básico. Ou seja, tanto a crise fiscal como também a política eram agravadas pela perdularidade, ineficiência, baixa cobertura e completa inadequação social do sistema de assistência à saúde ${ }^{70}$.

A inadequação da assistência à saúde não era opinião somente da oposição ao regime $^{71}$, políticas focalizantes e medidas pontuais, como o Programa de Interiorização das Ações de Saúde e Saneamento do Nordeste (Piass) e os

ter, desde 1977-78, condições políticas de iniciar um ataque frontal aos mecanismos estatais de corporativização das classe trabalhadoras assalariadas" (p. 66).

69 Sobre esse período, escreve Oliveira (1987): "O período que se segue a meados dos anos 70, no qual instala-se, progressivamente, o que designamos [...] como uma 'crise político-financeira' do modelo assistencial estabelecido nos anos anteriores. 'Crise' esta que não passa, na verdade, de uma expressão setorial da situação mais abrangente, de crise - simultaneamente econômica e política, 'de legitimação' e 'fiscal' - que o regime autoritário atravessou, naqueles anos de fim do anterior período de crescimento acelerado da economia e início do chamado processo de 'abertura' política" (p. 360-1).

70 Sobre os papéis econômicos e político-ideológicos das políticas sociais, escreve Oliveira (1987): "Tendo-se como exemplo de determinações de natureza 'econômica' (digamos assim), nesta área, circunstâncias como: a necessidade de garantir níveis mínimos de reprodução e manutenção da força de trabalho; o papel dos gastos públicos como 'contratendência à queda tendencial da taxa de lucro'; ou as pressões de produtores privados de determinados bens e serviços para a ampliação do mercado de seus produtos, etc - E, como exemplos de determinações de natureza 'política ideológica', circunstâncias como: a necessidade de garantir níveis mínimos de aceitação da ordem política dada, pela incorporação de parte das demandas de setores subalternos; ou as pressões oriundas da 'lógica' de constituição das 'máquinas' político-partidárias: idem para as pressões oriundas de interesses intraburocráticos, etc." (p. 374).

71 Sobre isso relata Paim (2008): "Técnicos do governo perguntavam por que motivos a 'Revolução' não conseguia por ordem no caótico sistema de assistência médica e sanitária" (p. 70). 
Programas de Extensão de Cobertura (PECs) ${ }^{72}$, passaram a ser aplicadas ainda no Governo Geisel (1974-79), mas eram medidas tímidas, que buscavam atuar sem contrariar os interesses privados na área.

Com o aprofundamento da crise política e a piora nas contas do Estado, o Governo Figueiredo (1979-1985) precisaria propor mudanças mais contundentes:

"Ao contrário do que se podia esperar daquele governo, tendo em vista o III PND [Plano Nacional de Desenvolvimento], a VII Conferência Nacional de Saúde (CNS) realizada em março de 1980, constituiu-se num marco do chamado discurso "democrático-social" do Estado brasileiro. [...] Como explicar, que esse mesmo governo apresentasse durante a VII CNS um discurso "democrático-social", enfatizando a atenção primária da saúde, anunciando o Programa Nacional de Serviços Básicos de Saúde (PrevSaúde), apelando para a "participação social" e prometendo o resgate da "dívida social" para com os excluídos do processo de desenvolvimento brasileiro?" (PAIM, 2008, p. 84)

Ainda que o Prev-Saúde tenha sido lançado na VII CNS com o aval do próprio Presidente da República, foi recebido com grande resistência por parte da burocracia previdenciária e por entidades influentes no setor, como a Abramge, a Federação Brasileira de Hospitais $(\mathrm{FBH})$ e a Associação Médica Brasileira ( $\mathrm{AMB})$. Mesmo que fosse preciso ampliar a legitimidade do Estado junto às populações mais empobrecidas e também aplicar à assistência previdenciária medidas racionalizadoras, o governo militar, dada a natureza de sua base de apoio, se mostrava naquele momento incapaz de agir - depois de muito debate e diversas versões do projeto, o Prev-Saúde foi “engavetado”, em meados de 1981.

Apesar de o Prev-Saúde não ter sido implementado, mantinha-se a necessidade de lidar com a "Crise da Previdência", que tinha o crescimento dos custos da assistência médica como um dos seus principais componentes. Ainda em setembro de 1981, por decreto presidencial, foi criado o Conselho Consultivo da Administração de Saúde Previdenciária (Conasp), órgão colegiado que recebia a clara missão de sugerir e planejar medidas para o controle de gastos ${ }^{73}$. O Plano do

72 Com forte influência dos serviços da SESP e da medicina comunitária estadunidense, eram abordagens que tentavam enfrentar a escalada de custos da medicina hospitalocêntrica com uma abordagem comunitária, mais voltada para a promoção e prevenção em saúde.

73 "Art. $4^{\circ}$. O CONASP, no desempenho de suas atividades, observará os seguintes princípios: [...] I compatibilização com as diretrizes do Governo para os setores da Previdência Social e da Saúde; [...] II - melhoria da assistência à saúde dos beneficiários e ênfase no atendimento básico, com redução de custos unitários e controle dos gastos; [...] III - integração das atividades de recuperação com as de proteção e promoção da saúde; [...] IV - descentralização de atividades e adequada participação 
Conasp, como ficou conhecido o projeto resultante, contava principalmente com medidas racionalizadoras, mas também com algumas que avançavam no processo de descentralização institucional e maior participação dos estados e municípios, como as que deram origem às Ações Integradas de Saúde (AIS), consideradas "estratégia-ponte" para a reorganização dos serviços de saúde (PAIM, 2008).

Paim (2008) e Faleiros (2006) atribuem o aspecto progressista de algumas das políticas do Governo Figueiredo à presença de quadros da RSB infiltrados na burocracia estatal. Sobre essa presença no Conasp:

"[...] começa a compor um quadro com um conjunto de técnicos e entre eles encontra-se o Eleutério, que era um quadro comunista importante, que militava no Cebes. [...] O Eleutério, então na secretaria técnica, passa a ter uma influência muito grande, tentando colocar nossas ideias dentro do conjunto de políticas propostas pelo Conasp" (TEMPORÂO apud FALEIROS et al., 2006, p. 69-70).

Mesmo considerando os imperativos que compeliam o último governo militar a realizar mudanças, como as crises do orçamento da Previdência e da União e a necessidade de garantir uma transição "por cima", "pacífica" e "ordeira", não há de se negar que o conteúdo dessas medidas era surpreendentemente progressista. A qualidade técnica das formulações dos intelectuais da RSB (portadores muitas vezes de propostas consonantes às necessidades de racionalização do governo), aliada ao momento político que vivia o país, de reorganização da classe trabalhadora e agitação social - momento no qual as bandeiras de democracia, combate à desigualdade e construção de justiça social ganhavam maior legitimidade - certamente contribuíram para a permeabilidade de que gozou parte das idéias da RSB no Governo Figueiredo e mais ainda no início do Governo Sarney.

Faleiros et al. (2006) caracterizam o período de transição da ditadura para a chamada Nova República da seguinte forma:

"Instaurou-se uma transição negociada entre segmentos dissidentes da base de sustentação do regime anterior e segmentos oposicionistas também emergentes da democracia de fachada consentida pelo Estado autoritário, em um pacto pelo alto, das elites, excluindo a participação popular que se manifestara, em ampla mobilização, na Campanha das Diretas-Já" (p. 44)

dos setores públicos e privado; e [...] $\mathrm{V}$ - eliminação de procedimentos e práticas que conduzam a distorções nas formas de atenção à saúde e à elevação desnecessária do gasto" (BRASIL, 1981). 
O Governo Sarney se configurou, portanto, a partir de uma heterogeneidade de forças políticas, conservadoras e progressistas, "o que acabou resultando em um jogo de interesses opostos, privatistas de um lado, estatizantes, de outro, sem uma nítida hegemonia de uma das partes" (p. 46). Essa correlação de forças interna do Governo se materializava também na composição dos ministérios, o que propiciou que Waldir Pires fosse Ministro da Previdência e Assistência Social, e que quadros da intelectualidade da RSB assumissem postos na burocracia estatal, tais como Hésio Cordeiro na presidência do Instituto Nacional de Assistência Médica da Previdência Social (Inamps), Eleutério Rodriguez Neto na Secretaria geral do Ministério da Saúde e Sérgio Arouca na presidência da Fundação Oswaldo Cruz (Fiocruz) (PAIM, 2008).

Paim (2008) resgata que, nesse contexto, foi possível dar seguimento a algumas medidas que buscavam reorganizar o sistema de saúde aqui já elencadas, como expansão das AIS, medidas de apoio à descentralização gerencial e de fortalecimento dos serviços públicos. A polêmica proposta de transferência do Inamps para o Ministério da Saúde abre a possiblidade de articular dentro do governo a convocação de uma conferência de saúde ampla. A VIII CNS, realizada em 1986, foi a primeira com ampla participação dos profissionais de saúde e setores populares, e foi organizada para discutir três eixos principais: saúde como direito, reformulação do sistema nacional de saúde e financiamento do setor saúde. Tanto a mobilização política que o processo de construção da VIII CNS permitiu, como também o seu relatório final foram importantes para as disputas que se seguiriam na construção do direito à saúde, na Constituinte e após ela.

Se condições objetivas apontavam a necessidade de uma reforma (ainda que voltada ao gerenciamento das crises de legitimação e fiscal do Estado), e o momento político legitimava intelectuais progressistas para conduzir esse processo em direção à democratização e ampliação do acesso, permitindo inclusive a formulação de um projeto de Reforma Sanitária com potencial subversivo ${ }^{74}$, as

74 Sobre essa questão escreve Oliveira (1987): "Assim, se o período ainda em curso no âmbito da Política de Saúde no Brasil tem sido marcado por uma tensão, entre, por um lado, mesquinhos interesses econômico-corporativos enraizados nessa área, e, por outro, esforços racionalizadores, que compõem, em última análise, um projeto de recuperação da eficácia político-ideológica das Políticas Sociais enquanto instrumento de hegemonia; o período que hoje se esboça deveria, a meu ver - se quer configurar-se como algo efetivamente novo - ser marcado por uma tensão entre projetos de hegemonia alternativos" (p. 363) 
movimentações da classe trabalhadora especificamente voltadas para a pauta da saúde parecem ter sido contraditórias. Sobre isso escreve Paim (2008):

\begin{abstract}
"De outro modo, as classes populares e os trabalhadores em particular, diante da recessão e do desemprego priorizavam lutas pela garantia do emprego e contra o arrocho salarial. Nesse contexto, mobilizações políticas de massa em função da questão saúde restringiam-se eventualmente a lutas corporativas de categorias profissionais. Ação política das classes populares pela redefinição das políticas de saúde cada vez mais tornava-se figura de retórica, ainda que repercussões da crise nas condições de saúde da população pudessem recolocar a saúde como parte substantiva da questão social" (p. 94).
\end{abstract}

Nas disputas cotidianas com o patronato, portanto, muitas vezes a garantia para si próprios de esquemas alternativos de assistência médica vinha à frente das demandas pela construção de um sistema universal e equânime ${ }^{75}$. Apesar disso, algumas entidades representantes da classe trabalhadora apresentavam posições políticas importantes de apoio ao projeto da RSB, como pode ser observado pela participação da Central Única dos Trabalhadores (CUT) na VIII CNS e também pela composição da Plenária Nacional de Saúde.

Não somente entidades da sociedade civil mostravam apoio ao projeto da RSB, mas também o fazia parte da burocracia estatal, principalmente no âmbito dos estados e municípios. Essa importância ficaria mais evidente a partir do início da década de 1990, quando a articulação dos secretários municipais de saúde passaria a ser o núcleo dinâmico do movimento pela construção do SUS, apesar disso, desde muito antes já se mostraria a relevância desses atores. É possível apontar momentos importantes de sua participação em cada fase da RSB e alguns desses acontecimentos narrados por Paim (2008): o primeiro Encontro de Secretários Municipais de Saúde das capitais do Nordeste (1978), considerado pelo autor importante marco na formulação do projeto da RSB; a criação do Conselho Nacional de Secretários de Saúde (Conass), em 1982 e também o engajamento dos secretários estaduais na implementação das AIS e do SUDS (Sistema Unificado e Descentralizado de Saúde), apontados como centrais na implementação de "estratégias-ponte" que viriam a viabilizar a construção de facto do novo sistema de saúde; e também a articulação dos secretários municipais de saúde, da qual é fruto

75 Muito embora tal questão seja motivo de polêmica, a cobertura por convênios de parte importante dos trabalhadores urbanos dos setores mais dinâmicos da economia, assim como também para os empregados pela burocracia estatal, mostra que sua postura frente à construção de um sistema único de saúde era, no mínimo, controversa. 
a criação do Conselho Nacional de Secretários Municipais de Saúde (Conasems), que mostrou-se muito importante no processo da Constituinte e também após, na criação das leis 8080/90 e 8142/90.

Esse ativo engajamento dos governos estaduais e municipais em ampliar o acesso à saúde em serviços gerenciados por si próprios, desde um momento no qual eram raros os governos mais próximos às forças populares, destaca a importância que pode adquirir o aumento da assistência médica enquanto tática para alcançar maior legitimidade e aprovação por parte desses governos em nível local. Tal elemento é absolutamente relevante para entender não somente o curso da RSB, mas também para entender a expansão da assistência pública à saúde desde a redemocratização e a forma que tomam esses serviços nos dias atuais. Discutiremos mais sobre esse aspecto no capítulo seguinte.

Da participação e da importância dos diferentes atores envolvidos no processo da RSB, portanto, é possível depreender que, mais que um amplo e pujante movimento de massas que teria derrotado politicamente os setores "antireforma", o movimento da RSB, através da ocupação de espaços na burocracia estatal e da formulação de um projeto técnico-político condizente com as necessidades desse Estado, teria se aproveitado de uma crise de hegemonia no seio do Estado brasileiro para inserir, nos marcos daquela transição democrática "por cima”, elementos progressistas à necessária reforma das políticas de saúde ${ }^{76}$.

Tal conjuntura pode ser observada nas próprias movimentações da Assembleia Nacional Constituinte, em 1988. Enquanto outros setores elaboraram propostas de emenda com grande apoio popular, como a da Reforma Agrária com 3 milhões de assinaturas e a do Ensino Público com mais de 1 milhão, a emenda popular apresentada pelo movimento da RSB contava apenas com 54 mil assinaturas. Em comparação, a proposta apresentada por representantes da

\footnotetext{
76 Para Oliveira (1987), diferentemente da reforma sanitária italiana, que se constituiu enquanto um processo "de fora para dentro" ou "de baixo para cima", ou seja, "decorrente da aglutinação de diferentes movimentos sociais" (p. 364), a RSB teria sido um movimento "de dentro para fora", ou "de cima para baixo", no qual teriam sido protagonistas "um conjunto de técnicos" progressistas, muitos deles ocupando "postos e posições significativas no interior do aparelho do Estado". Oliveira também diferencia os dois processos apontando que na Itália a reforma sanitária era, desde o início, parte de um projeto político de transição para o socialismo, enquanto que, no Brasil, o termo "Reforma Sanitária" era muitas vezes utilizado somente para designar o conjunto de medidas institucionais racionalizadoras que já vinham sendo propostas pelo governo federal desde o final da década de 1970.
} 
assistência privada, como a Associação Brasileira de Medicina de Grupo (Abramge) e a Federação Brasileira de Hospitais (FBH) tinha cerca de 70 mil assinaturas (PAIM, 2008).

Apesar disso, dentre as diferentes frações capitalistas atuantes no setor saúde, parecia ser justamente aquela ligada à prestação de serviços de assistência a que tinha o menor poder político:

"Foi impressionante porque a gente sentia essa questão da correlação de forças. Na área de medicamentos nós não conseguimos avançar nada. Todos os grupos que participavam da Plenária eram favoráveis à incluir maior controle, a questão dos genéricos, e eu me lembro que o relator da Constituição retirou o item sobre os medicamentos, alegando que havia recebido um telegrama da Abifarma e considerou que isso não tinha importância. Ou seja, esses que eram os mais poderosos, sequer nós os enfrentávamos. Foi quando a gente percebeu que a $\mathrm{FBH}$ não era tão poderosa, pois se estavam ali, como nossos supostos inimigos, eram os que precisavam do próprio Estado e nós podíamos medir forças com eles. Os outros nem apareciam, mandavam telegrama ou faziam o lobby deles sequer nos enfrentando - os grandes poderosos da área de medicamentos, saúde do trabalhador - tudo isso nós perdemos." (Fleury apud FALEIROS et al., 2006, p. 94).

Se o modelo organizado pela ditadura conseguiu articular os serviços de assistência à saúde mais diretamente à reprodução do capital, manteve também boa parte dessas empresas dependentes do Estado (BAHIA, 2005). Na necessária superação desse modelo perdulário e excludente, o setor não conseguiu formular e articular um projeto consistente:

"A saúde inovou porque nós tínhamos um projeto, que tinha sido construído durante um longo período de anos, e um projeto consolidado e pronto, através de várias frentes de discussão e de luta, e a direita e o centro não tinham. [...] nós tínhamos um projeto que foi negociado, melhorado, reformulado, perdemos algumas coisa, mas o cerne estava pronto há muito tempo" (FLEURY apud FALEIROS et al., 2006, p. 98).

O texto constitucional aprovado refletia a competência técnica e política com a qual a vanguarda do movimento da RSB tinha formulado e articulado seu projeto, mas dava também a medida de seus limites; o setor privado havia sofrido derrotas, mas mantinha boas condições para tocar e ampliar seus negócios. Muito do necessário para a concretização dessa reforma ainda estaria por ser construído. 


\subsection{A saúde no Brasil após 1988}

O ambicioso projeto da Reforma Sanitária Brasileira não pautou apenas uma mudança radical do sistema de assistência à saúde, mas uma reforma profunda das condições de vida da população brasileira e de suas relações com o Estado. A magnitude desse projeto, no entanto, não encontrava contrapartida em sua força e representação política; o plano mostrou-se, na prática, bastante mais difícil de alcançar do que permitiam, não só os recursos com que contavam, mas talvez também, os caminhos que o movimento trilhara ${ }^{77}$.

Se o movimento e o processo da RSB tinham suas deficiências e idiossincrasias, havia também uma conjuntura internacional que não favorecia a maior participação do Estado na consecução de direitos sociais. O longo declínio da URSS e do bloco socialista (que culminaria com a icônica queda do muro de Berlim, em 1989), e o seu correspondente nos países capitalistas centrais, com o avanço do projeto neoliberal e o recuo da classe trabalhadora organizada, resultavam num ataque frontal aos direitos dos trabalhadores em todo o mundo.

A eleição de Fernando Collor de Mello em 1989, com agressiva retórica neoliberal e também certo recuo dos trabalhadores e movimentos sociais no contexto de crise econômica, traziam essa conjuntura também para o cenário nacional. O Neoliberalismo e o "fim da história"78 dariam um projeto, uma narrativa, e também as ferramentas para que as classes proprietárias assumissem com maior segurança o controle político e econômico do país, e acabariam por erigir mais uma série de barreiras para a construção do direitos determinados na Constituição Federal de 1988.

\footnotetext{
77 Sobre isso escreve Cardoso (2013): "a Reforma Sanitária Brasileira encontrou desde cedo a sua encruzilhada: organizar uma estratégia política para enfrentar os bloqueios estruturais à construção da saúde como um direito requeria interpretá-los como contingência ou necessidade da sociedade dependente. Em outras palavras: no primeiro caso, o processo reformista teria condições objetivas e subjetivas para cumprir sua missão, uma vez que não haveria uma relação de determinação necessária com o passado colonial, a subordinação externa e a segregação social. No segundo caso, o capitalismo dependente seria absolutamente incompatível com a reforma social preconizada pelo movimento da RSB, e o movimento reformista, para ser consequente com seu próprio projeto, precisa estar organicamente vinculado à superação da ordem" (p. 224).

${ }_{78} \mathrm{~A}$ famosa tese de Francis Fukuyama aparecia como a narrativa perfeita para o Neoliberalismo em um mundo pós-URSS; para seus defensores, aquele era o fim das disputas dos grandes projetos, só o que haveria restado era o Capitalismo Liberal, e todos deveriam, cedo ou tarde, render-se às suas maravilhas. A própria história, no entanto, teima em dar-se por inacabada.
} 
$\mathrm{Na}$ área da saúde, esse projeto pode ser bem exemplificado pelos documentos do Banco Mundial, com recomendações para o setor. Rizzotto (2012) faz extensa análise das políticas propostas por essa instituição.

A partir de seu trabalho é possível observar que, mesmo com algumas mudanças ao longo do tempo, as orientações do Banco têm entre si uma lógica que Ihes dá coerência; a maximização dos efeitos econômicos (no sentido da reprodução do capital) e políticos (no sentido de estabilização e manutenção da ordem capitalista) obtidos através do investimento estatal em saúde.

No primeiro documento voltado para o setor, de 1975, tal orientação já fica clara. Ela será expressa ali, assim como em documentos futuros, nos termos de recomendações para a diminuição dos gastos em assistência, principalmente aquela de alto custo e complexidade, e aumento dos investimentos em ações populacionais, de prevenção e promoção, assim como em serviços de saúde básicos, voltados para os mais pobres.

"O princípio básico da reforma dos sistemas de saúde vai desde a necessidade de mudar a orientação quanto ao tratamento individual de alto custo das enfermidades com critério unicamente curativo por outra de promoção da saúde sobre uma base contínua em nível da comunidade [...]. O serviço de saúde reformado oferecerá cuidados curativos limitados com base em medicamento-padrão e procedimentos simples que podem ser administrados sobre a área por trabalhadores de saúde que tenham recebido um treinamento breve (BANCO MUNDIAL, 1975, p. 55 apud RIZZOTTO, 2012)

Se tal orientação parece subestimar a importância da assistência a saúde na manutenção da força de trabalho e dos investimentos do Estado na assistência como subsídio indireto à produção de bens e serviços, outro trecho do mesmo documento parece esclarecer a questão:

\footnotetext{
"Agora bem, em razão do considerável nível de emprego e subemprego existente nos países em desenvolvimento, a mortalidade prematura pode não impor por si mesma um custo econômico. Se a má saúde resulta na substituição, sem nenhum custo, dos trabalhadores falecidos por trabalhadores desempregados sãos, pode ser que não se registre declínio da produção. A morbidade da força de trabalho que causa absenteísmo ao trabalho pode ter maior impacto econômico. O absenteísmo interrompe em geral o processo de produção e, em condições de desemprego elevado, a substituição temporária dos trabalhadores ausentes é provável que resulte em perda de produção" (BANCO MUNDIAL, 1975, p. 30-1 apud RIZZOTTO, 2012).
} 
Ou seja, segundo a lógica implícita no documento, mesmo considerando o efeito de subsídio indireto que o investimento estatal em saúde teria sobre a produção de bens e serviços (ao diminuir os custos da manutenção e reprodução da força de trabalho), seria contraproducente investir em cuidados hospitalares de alta custo que pudessem evitar a mortalidade por condições de saúde mais graves. $\mathrm{O}$ importante seria manter serviços de saúde que diminuíssem o absenteísmo e garantissem a ampla disponibilidade de outros trabalhadores (desempregados) saudáveis, para substituir aqueles mais gravemente adoecidos.

Tal visão certamente justificaria tanto a ênfase em programas de saúde materno-infantil e em programas "comunitários" de prevenção e promoção à saúde, como também a grave condenação do investimento em serviços "curativos". Ainda mais, para os trabalhadores pouco qualificados dos países em desenvolvimento, 0 importante não seria a reabilitação ou o cuidado daqueles indivíduos adoecidos, mas sim a ampla disponibilidade de indivíduos saudáveis (jovens) para a rápida reposição da força de trabalho.

Os setores mais qualificados da força de trabalho, por outro lado, teriam condições de financiar a própria assistência em saúde, não justificando o investimento estatal e devendo o seu cuidado ser assumido pela iniciativa privada voltada para o lucro.

"Nos países em desenvolvimento, os grupos prósperos da população têm capacidade econômica para obter a preços de mercado a maioria dos serviços de saúde de que necessitam, por isso não se justificam facilmente as subvenções públicas a tais grupos, qualquer que seja o critério que se invoque" (BANCO MUNDIAL, 1975, p. 37 apud RIZZOTTO, 2012).

De certa forma, o documento de 1975 é incipiente, e mostra as intenções do Banco na sua crueza utilitarista. As propostas da entidade formuladas na década de 1990, por outro lado, são mais bem acabadas, e adquiririam mais facilmente a aparência de republicanas e democráticas. As propostas de focalização e copagamento viriam sempre acompanhadas das (justas) críticas à iniquidade do sistema de saúde brasileiro. As propostas de descentralização operacional e financeira, assim como também as de flexibilização do orçamento e legislação federais, apareceriam como modernas ou democratizantes. No fundo, ambas estariam voltadas para a simples contenção de custos ou para a introdução de reformas privatizantes. 
Os relatórios "Brasil novo desafio à saúde do Adulto" (BANCO MUNDIAL, 1991) e "A organização, prestação e financiamento da saúde no Brasil: uma agenda para os anos 90" (BANCO MUNDIAL, 1995) viriam como que em resposta ao que Banco Mundial via como "propostas idealistas" contidas na CF de 1988. Em um contexto político e econômico já bastante diferente àquele da década de 1970, os documentos produzidos na década de 1990 trariam de forma mais bem acabada propostas que visavam garantir não somente a realização de superávits para o pagamento da dívida pública, mas a própria reforma do aparelho do Estado.

Sobre a influência dessas recomendações nas políticas de saúde brasileiras na década de 1990 escreve Rizzotto (2012):

"Contudo, essas divergências manifestadas por setores do Ministério da
Saúde não foram suficientes para impedir a assimilação das orientações
do Banco Mundial nas reformas implementadas no setor saúde nos anos
de 1990 , ao contrário, muitas sugestões contidas nos documentos do
Banco Mundial, foram incorporadas aos discursos de representantes do
governo à época, ou mesmo passaram a fazer parte das estratégias
prioritárias do Ministério da Saúde. Identificam-se sinais dessa assimilação
na proposta do setor de saúde, apresentada pelo Ministério da
Administração Federal e Reforma do Estado, em 1995, e pelo Ministério da
Saúde [...]; na reforma da previdência; na tentativa de criar, na opinião
pública, um consenso sobre a necessidade de restrição dos direitos de
universalidade, equidade e integralidade da assistência; na centralidade
que o Programa dos Agentes Comunitários de Saúde (PACS) e o
Programa Saúde da Família (PSF) assumiram no conjunto das políticas do
Ministério da Saúde no período estudado, os quais visam à focalização e
seletividade dos serviços de atenção à saúde; no estímulo à participação
da iniciativa privada na prestação de serviços de saúde, com a abertura do
mercado para empresas estrangeiras e, no estabelecimento de acordos de
empréstimos com o Banco Mundial para o desenvolvimento de projetos na
área da saúde, que visavam a implementação de propostas condizentes
com a agenda e os objetivos da instituição" (p. 152-3)

Mas se continham críticas e propunham alternativas a princípios estruturantes do direito à saúde como presente na CF de 1988, como a integralidade e a cobertura universal, apresentariam também propostas que, ao menos na aparência, seriam bastante similares àquelas defendidas pelo próprio movimento da RSB. Rizzotto (2012) demonstra como a aparente sintonia entre as propostas escondiam, muitas vezes, sutilezas que apontavam propósitos e resultados bastante diversos. É possível, no entanto, que a similaridade de algumas das propostas tenha moldado a construção das políticas de saúde nas décadas de 1990 e 2000. A descentralização, por exemplo, parece ter permitido tanto a construção de experiências progressistas, 
de fortalecimento do direito à saúde e ampliação da participação popular, como também a execução de projetos ultra-privatizantes, como o PAS de São Paulo. Isso sem falar na "colonização" das políticas de saúde pelos interesses privados das velhas oligarquias locais em incontáveis municípios por todo o país.

Outro exemplo importante dessa aparente "sintonia" entre o discurso do movimento da RSB e aquele do Banco Mundial é a crítica ao caráter excessivamente especializado e hospitalar do sistema de saúde herdado da ditadura. Na realidade, mesmo que ambos os projetos se opusessem ao arranjo específico do sistema de saúde construído pelo regime de 1964 (que trazia em si cristalizados os interesses do setor privado prestador de serviços e da corporação médica), eles tinham, na verdade, objetivos diferentes. O movimento da RSB defendia a mudança desse perfil na direção da construção de um sistema de saúde que realizasse prevenção, promoção, cura e reabilitação - de acordo com as necessidades de saúde da população. O Banco Mundial defendia focalização e máximo custo-benefício, nos termos já discutidos acima. Aqui, novamente, a realidade se mostra a expressão dialética das contradições entre os dois projetos: ao mesmo tempo em que grande parte da expansão do acesso à saúde pós-1988 tenha se dado por meio da expansão de serviços de "Atenção Básica"79, voltados para populações mais pobres, conforme ditava o receituário do Banco, a construção desses serviços muitas vezes significou concretamente, para as populações cobertas, um avanço na consolidação do direito à saúde, inclusive se observados os seus princípios de universalidade, integralidade e equidade.

O sistema de saúde que começa a ser construído a partir de 1988 traz em si os avanços conquistados no bojo da redemocratização, mas traz também a pesada herança histórica das políticas de saúde e arranjos assistenciais das décadas

\footnotetext{
79 Para mais dados, ver Paim et al. (2011). Dentre outros dados interessantes, o artigo aponta que o número de "postos e centros de saúde" no país cresceu de 8767, em 1981, para 41667, em 2010, e o número de "ambulatórios especializados" passou de 6261 para 29374 no mesmo período. Muito embora ambos os tipos de serviço tenham tido crescimentos bastante expressivos (muito maior que o do número de hospitais, por exemplo, que passou de 5660 para 6384 no mesmo período), esse crescimento se deu de forma bastante diferente entre os setores públicos e privados. A proporção dos "postos e centros de saúde" que eram públicos se manteve praticamente a mesma entre 1981 e 2010, aproximadamente $99 \%$. Enquanto isso, a proporção dos "ambulatórios especializados" que eram públicos caiu de $53,9 \%$ em 1981, para somente 10,7\% em 2010. Isso demonstra que, enquanto a expansão do setor público se deu principalmente pela expansão dos serviços de Atenção Básica, a do setor privado se deu principalmente através da expansão da atenção ambulatorial especializada.
} 
passadas. Tem ao seu lado a CF de 1988, mas precisa conseguir avançar em plena ofensiva do projeto neoliberal.

Nesse contexto contraditório, é possível identificar avanços, mas também continuidades e retrocessos. Não é nossa intenção aqui fazer detalhada descrição do SUS de hoje, nem resgatar detalhes de sua construção, mas, assim como tem sido feito até agora nesse capítulo, apenas apontar elementos gerais que nos permitam entender a evolução do sistema de saúde na sua articulação com a dinâmica da luta de classes.

A expansão do acesso e a consolidação do direito à saúde é certamente um dos principais avanços a serem observados no período pós-1988. Se antes da CF de 1988 o acesso a serviços de saúde só era garantido àqueles que estivessem segurados pela Previdência ou àqueles que tivessem condições de pagar por atendimento médico (seja por meio da contratação de convênios, seguros ou desembolso direto), no período posterior é possível dizer que a grande maioria da população tem acesso a serviços de saúde. Dados da Pesquisa Nacional de Saúde de 2013 (PNS 2013) mostram que, dentre os mais de 30 milhões de brasileiros que tinham buscado atendimento médico até duas semanas antes da realização da pesquisa, 97,0\% conseguiram atendimento, sendo que 95,3\% foram atendidos na primeira vez em que procuraram (IBGE, 2014). Outro dado que pode indicar de maneira indireta a maior facilidade de acesso a serviços de saúde é a proporção de pessoas que acessou serviços de saúde no último período. Em 1981, somente 7,7\% dos brasileiros que responderam à Pesquisa Nacional por Amostra de Domicílios (PNAD 1981) haviam acessado serviços de saúde no mês anterior, na PNS 2013, aproximadamente $15 \%$ dos entrevistados haviam acessado serviços de saúde nas últimas duas semanas (IBGE, 1984; 2014).

É importante também apontar alguns dos avanços institucionais que permitiram o fortalecimento das redes de assistência e a mudança do perfil na utilização dos serviços financiados com recursos públicos. Se no período anterior ao SUS o atendimento era realizado, em grande parte, por serviços de saúde desarticulados entre si, com grande participação de ambulatórios especializados e do atendimento hospitalar, após a CF de 1988 é possível observar maior articulação entre os serviços, com maior participação dos serviços de APS. 
Parte desses avanços foi possível graças à descentralização do sistema de saúde. Segundo Paim et al. (2011), essa descentralização foi a "lógica subjacente" da implementação do SUS, sendo necessário para isso a criação de um intrincado conjunto de leis, normas e regras, que envolviam desde a definição das responsabilidades institucionais de cada nível de governo até mecanismos de repasses financeiros entre as três esferas. Concomitante a essa descentralização foram construídas instâncias de participação popular em todos os níveis de governo e em muitos serviços públicos, numa articulação que envolve desde os conselhos locais até as Conferências Nacionais de Saúde. A criação e a articulação dessas instâncias foram responsáveis pelo aumento na participação de cidadãos e entidades da sociedade civil na discussão institucional das políticas de saúde, apesar disso, a fragilidade e o limite dessas instâncias ficou cada vez mais claro ao longo dos anos. O desrespeito às determinações desses conselhos acabou se mostrando a regra, sempre que as mesmas divergiam daquelas defendidas pelos governos (BALLAROTTI, 2012). Sobre os limites da inclusão de novos atores na determinação das políticas públicas, já escrevia Oliveira em 1987:

"Mas, se esta participação não se fizer com consciência de todas as restrições anteriormente apontadas, e com a disposição de entrentá-las, corre o risco de levar apenas a novas formas de cooptação e 'transformismo'. [...] E, com isso, retornamos ao núcleo da nossa discussão. Ou seja: à idéia de que a mera incorporação de novos (e mesmo heterodoxos) atores ao 'policy-making' governamental, sem que esta incorporação se faça acompanhar de uma problematização e um enfrentamento dos temas básicos da 'quebra' do Estado, e da luta pela hegemonia, apenas nos levará, na melhor das hipóteses, a repor, de uma forma modernizada e atualizada, a estratégia social-democrata de mera 'ocupação' e gestão 'humanizada' do Estado capitalista, com as conhecidas consequências políticas deste fato" (OLIVEIRA, 1987, p. 3801)

E apesar da clara ampliação do acesso e dos avanços institucionais na construção de redes de saúde, muito do necessário ainda permanece por fazer. Parte desse problema decorre do financiamento insuficiente a que tem sido submetido, desde o início, o Sistema Único de Saúde.

Sobre o subfinanciamento do SUS e suas consequências, portanto, é importante, inicialmente, discorrer sobre quais eram as determinações da CF de 1988. Segundo Mendes (2012), era previsto pela Constituição que a Seguridade Social (área composta pela saúde, previdência e assistência social) tivesse um 
orçamento próprio, que não integraria o orçamento da União. Esse orçamento deveria ser composto por:

"recursos provenientes dos orçamentos da União, dos Estados, do Distrito Federal e dos Municípios", e das contribuições sociais dos empregadores (incidentes sobre a folha de salários, o faturamento - Contribuição para Financiamento da Seguridade Social (Cofins) - e o lucro - Contribuição sobre o Lucro Líquido - CSLL), dos trabalhadores e $50 \%$ da receita de concursos e prognósticos (loteria)" (MENDES, 2012, p. 116).

Por meio de lei complementar, ficou determinado que, desse Orçamento da Seguridade Social, 30\% dos recursos deveriam ser destinados ao SUS. Acrescidos a esse montante, ainda deveriam ser aplicados recursos provenientes dos orçamentos estaduais e municipais. Nenhum governo desde então jamais cumpriu integralmente tais determinações, pelo contrário, o que se viu desde então foi a aplicação de uma série de medidas para tentar desconstruir ou burlá-las.

O grave desfinanciamento a que foi submetido o SUS, desde o início, acabou por criar importantes barreiras no acesso, fazendo com que, muitas vezes, a universalidade e a integralidade do nosso sistema de saúde não se demonstrassem na realidade. Filas que demoram meses ou anos para o acesso a exames e especialistas foram, desde o princípio, lugares comuns para o SUS das grandes cidades. Nas localidades menores, principalmente no Norte e Nordeste, a desassistência chegou muitas vezes a ser completa. A dificuldade de acesso, e os limites da assistência oferecida pelo SUS, certamente foram, em parte, responsável pela grande ampliação do mercado de seguros e convênios médicos no final da década de 1980 e na década de 1990.

Mendes (2012), ao descrever o período, fala sobre a disputa entre o "princípio da construção da universalidade" e o "princípio da contenção de gastos", que aqui entendemos como a representação dos conflitos entre: por um lado, os setores populares e os atores que haviam lutado pela reforma sanitária; e, por outro lado, setores das classes proprietárias (com destaque para o capital financeiro) e da burocracia estatal alinhados ao "Consenso de Washington". O autor rejeita a existência de uma simples sucessão temporal ou de um movimento pendular entre as duas lógicas, afirmando a natureza dialética da articulação entre as classes na determinação dessas políticas do Estado. 
Considerando essas duas lógicas conflitantes, há algumas movimentações que merecem ser resgatadas. A primeira delas é a fragilização, e mesmo o afastamento completo, na divisão dos recursos, do conceito de Seguridade Social. Já em 1989 e 1990 os recursos da Seguridade Social não seriam completamente destinados a esse fim, problema que se agrava nos anos seguintes. A partir de 1993, no contexto das disputas de orçamento entre Previdência Social e Saúde, as contribuições de empregados e empregadores passam a ser utilizados somente para a Previdência Social, arranjo que estrangula ainda mais o orçamento da saúde. Em 1994, é criado o Fundo Social de Emergência, posteriormente chamado de Fundo de Estabilização Fiscal e, por fim, a partir de 2000, denominado Desvinculação das Receitas da União (DRU). Com a DRU, 20\% da arrecadação das contribuições passariam a ser, naquele momento, desvinculadas de sua finalidade, podendo ser utilizadas pelo Governo Federal para outros fins. Segundo Mendes (2012):

"A DRU transforma os recursos direcionados ao financiamento da
seguridade social em recursos fiscais para contribuir com o superávit
primário, defendido pela política fiscal restritiva do governo federal, e a sua
utilização em pagamentos de juros da dívida pública. Trata-se de
reconhecer, aqui, que o capital portador de juros, em busca de sua
valorização, necessita da liberação de recursos do fundo público do
Orçamento da Seguridade Social [...] A criação desse mecanismo
significou, de um lado, o atendimento às exigências do capital financeiro, e
de outro, o rompimento do que estava estabelecido na Constituição
Federal" (MENDES, 2012, p. 120).

Já a partir de 1993, na esteira dos problemas de financiamento que vinha enfrentando a saúde, foi realizada a Proposta de Emenda Constitucional (PEC) 169, que buscava vincular recursos financeiros específicos para a saúde - além de propor o reestabelecimento para a saúde de fundos que atingissem a proporção de ao menos $30 \%$ do Orçamento da Seguridade Social, acrescia também $10 \%$ da receita de impostos, entre transferências da União, estados e municípios. Perdendo bastante de seu conteúdo original, a PEC foi aprovada em 2000, sob a denominação de EC 29. Em 1994 foi proposto também um Imposto Provisório sobre a Movimentação Financeira, que viria a ser aprovado em 1997 sob o nome de Contribuição Provisória sobre a Movimentação Financeira (CPMF).

A EC 29 provavelmente foi responsável por aumentar o gasto público em saúde no Brasil de 2,9\% do PIB em 2000, para 4,0\% do PIB em 2009 (MENDES, 
2012, p. 134), mas o gasto líquido do governo federal, com ou sem EC 29 ou CPMF, manteve-se praticamente constante no período de 1995 a 2015, variando sempre muito próximo a 1,7\% do PIB (p. 123). Isso demonstra como esse aumento se deveu principalmente ao aumento dos gastos de estados e municípios. Se os gastos em saúde do governo se mantiveram sempre em torno de $1,7 \%$ do $\mathrm{PIB}$, os gastos do governo federal com juros e encargos da dívida variaram no mesmo período entre $5 \%$ (1997 e 2010) e 9\% do PIB (1999 e 2003).

No que concerne ao gasto em saúde em relação ao PIB, o maior problema que o país enfrenta não é exatamente o volume dos recursos (ainda que esses também sejam um problema), mas sua distribuição. No ano de 2009, na soma de recursos públicos e privados, o Brasil gastou em saúde $8,8 \%$ do $\mathrm{PIB}$, número não tão distante de outros países com sistemas universais, como Reino Unido (9,8\%), Espanha $(9,6 \%)$, Canadá $(11,4 \%)$ e Austrália (8,7\%). No que se refere à proporção de gastos públicos nesse total, no entanto, o Brasil fica bem atrás. Na média, esses países tiveram em 2009 uma proporção de gastos públicos de aproximadamente $79 \%$, enquanto o Brasil ficou em apenas 47\%. O Brasil é único país no mundo com sistema universal de saúde no qual o gasto privado é maior que o gasto público.

Essa desproporção entre o gasto público e o gasto privado em saúde, em um país que deveria ter um sistema único e universal, reflete um problema crônico da assistência à saúde brasileira que o processo da RSB não logrou resolver, a sua profunda estratificação e a relação parasitária das empresas privadas de saúde para com o Estado brasileiro. Ademais, é importante ressaltar que até 2016, o financiamento do SUS não foi resolvido em termos de fontes definidas e suficiência de recursos para atender à integralidade e universalidade das ações e serviços de saúde ${ }^{80}$.

Sobre a estratificação da atenção à saúde e as relações parasitárias do setor privado para com o Estado brasileiro, portanto, é importante primeiramente lembrar que não se trata de um fenômeno novo. Como revela Bahia (2005), já é possível observar a constituição de esquemas alternativos de assistência médica por certas categorias profissionais desde a década de 1940. Processo que, como 
demonstra a autora (e discutido na seção 2.1.3), avança e amadurece por todo o período da Ditadura Militar.

O sistema de saúde herdado do regime de 1964 era, por si próprio, um verdadeiro obstáculo para a consecução do direito à saúde. Não tanto por ser em sua maioria composto por prestadores privados, em vez de estatais, mas principalmente por seu funcionamento ser a expressão de interesses particulares (principalmente aqueles dos capitalistas do setor, mas também da corporação médica). Para construir um sistema voltado para a expressão dos interesses públicos, nos termos do direito a saúde universal, integral e equânime, seria necessária uma série de mudanças na relação do Estado para com esse setor privado, como por exemplo: mudanças no modo da remuneração do setor, na ocasião de sua contratação pelo Estado; e o fim dos subsídios diretos e indiretos ao setor, principalmente aqueles dispostos para a viabilização de arranjos assistenciais "diferenciados" (como era o caso dos convênios com a medicina de grupo) ${ }^{81}$. Seria necessária forte regulação estatal para que, mesmo o setor voltado para o lucro, atuasse em consonância e em articulação com os princípios dos SUS, sem a utilização de recursos públicos de forma regressiva, para financiar o privilegiamento de certos setores. Enfim, sem a utilização de recursos públicos para o financiamento de iniquidades.

Se essas questões foram devidamente diagnosticadas pelos atores que construíram a RSB, chegando até a expressar-se nos termo de um antagonismo entre "estatização já" ou "estatização progressiva", na VIII CNS, os mecanismos realmente construídos para a mudança desse quadro foram absolutamente insuficientes.

Alguns exemplos dessa insuficiência são: a forma de remuneração das empresas privadas pelos serviços prestados ao SUS, que manteve o pagamento por procedimento realizado (fee for service); a persistência de diversas formas de subvenção estatal a arranjos assistenciais iníquos e regressivos, dos quais a dupla porta em hospitais públicos e os incentivos fiscais são somente dois dos exemplos mais evidentes; e o fraco controle e regulamentação do setor suplementar. Esses problemas, dentre outros, acabaram redundando num fortalecimento do setor

\footnotetext{
81 Para essa discussão, ver Mendes e Weiller (2015); Ocké-Reis (2013).
} 
privado voltado para o lucro e em um aprofundamento da segmentação do acesso, ainda que em novos termos.

Sobre o crescimento do setor privado escrevem Paim et al. (2011):

"Dados da Pesquisa Nacional por Amostra de Domicílios (PNAD) mostram que, em $1981,68 \%$ do total de atendimentos de saúde realizados no mês anterior à pesquisa foram financiados com recursos públicos, $9 \%$ por planos ou seguros de saúde privados e $21 \%$ por gastos por desembolso direto. Em 2003, a proporção do consumo de serviços de saúde financiados com recursos públicos caiu para $56 \%$, permanecendo nesse nível em 2008. Porém, a contribuição dos seguros de saúde aumentou de forma expressiva ( $21 \%$ da despesa total em 2008) - o volume de atendimentos financiados por esse setor cresceu $466 \%$ de 1981 a 1998. A proporção dos pagamentos do próprio bolso aumentou de forma contínua: passou de 9\% em 1981 e 1998 para 15\% em 2003 e 19\% em 2008. Em 1981, o sistema de previdência social pagou 75\% das internações hospitalares, enquanto em 2008 o SUS pagou apenas $67 \%$ das internações. Em 1981, 6\% das internações hospitalares foram pagas por planos de saúde privados, uma proporção que cresceu para $20 \%$ em 2008. Já a proporção de internações hospitalares pagas por desembolso direto (cerca de 10\% em 2008) se manteve constante desde 1981" (p. 21)

A prosperidade que o setor de serviços de saúde voltado para o lucro experimentou desde o final da década de 1980 nos permite também fazer uma breve análise política sobre o processo. Pois se a assimilação, por parte do discurso oficial do Estado, das críticas ao modelo de assistência da ditadura, com as exigências de maior efetividade das ações em saúde e racionalização dos recursos gastos no setor, assim como também diversas das características da expansão e do desenho institucional do SUS, podem ser considerados a expressão dialética das disputas entre os interesses neoliberais e os interesses populares (simbolizados, de um lado, pelas propostas do Banco Mundial e, do outro, por aquelas da RSB), a contínua expansão da assistência privada, e as fracas medidas no sentido do seu controle ou regulamentação, apontam para a acomodação, no arranjo do sistema de saúde brasileiro, também dos interesses do setor privado da saúde. E diferente do que se poderia imaginar pelos debates realizados na segunda metade da década de 1980, o setor foi, na verdade, muito bem acomodado.

A construção do direito a saúde, nessas muitas décadas, foi capaz de lograr importantes avanços no sentido de sua consolidação. Esses avanços podem ser demonstrados: tanto pela melhora do acesso de amplos setores da população a serviços de saúde públicos e gratuitos, como o PSF, o Programa Nacional de 
Imunização, o Serviço de Atendimento Móvel de Urgência (SAMU) e o Programa Nacional DST/AIDS; como também pelos importantes avanços institucionais relativos à construção de redes de saúde e à inclusão de um maior número de atores na formulação e execução das políticas de saúde.

Há também, no entanto, muitas características do sistema de saúde brasileiro de hoje que dão, não só a medida dos limites desse processo, como também o testemunho da força daqueles setores que pareciam ter sido derrotados no final da década de 1980. Dentre tais características, as mais eloquentes provavelmente são: o grave subfinanciamento a que tem sido submetido o SUS desde o seu início, redundando em importantes barreiras ao acesso e à integralidade; a manutenção de importante estratificação no acesso à assistência à saúde com base no emprego e na renda; a persistência de diversos subsídios estatais diretos e indiretos ao setor privado; e talvez o mais grave de todos - o progressivo agravamento de todos os problemas citados acima.

Como demonstrado na primeira parte desse capítulo, a construção das políticas de saúde e esquemas assistenciais estiveram, no Brasil, sempre intimamente ligadas à dinâmica da luta das classes. Cumpriram, de forma geral, portanto, o papel de: garantir o mínimo da manutenção e reprodução da força de trabalho, ainda que prioritariamente daquelas frações ligadas aos setores mais dinâmicos da economia; conseguir o apoio político, a obediência, ou apenas o apaziguamento dos trabalhadores (e novamente, na maior parte do tempo, somente parte deles); ao mesmo tempo em que garantia uma poupança compulsória voltada para impulsionar a reprodução do capital nos seus diferentes momentos. A medida do quanto o setor saúde teria papel predominante na mediação do conflito entre as classes, e do quanto se constituiria em ferramenta para impulsionar a reprodução capitalista, dependeria justamente da capacidade das classes despossuídas em representar seus interesses no âmbito do Estado, em oposição à capacidade das classes proprietárias em impor o seu domínio econômico e político.

No Estado Novo (1937-1945), o orçamento da Previdência garantiria o aporte de recursos para obras de infraestrutura e industrialização; na Ditadura Militar (19641985) garantiria, além disso, também a articulação do setor saúde à reprodução do capital. No período democrático de 1945 a 1964 e na redemocratização da década 
de 1980, a maior força política das classes subalternas garantiria uma série de concessões em direção ao fortalecimento da participação dos trabalhadores e da construção de direitos sociais.

É importante observar, no entanto, que a expressão dessa conjuntura se dá de maneira absolutamente dialética e contraditória. Se nos anos da Ditadura Militar predominaram a "lógica dos negócios", foi também nesse período em que aconteceu a maior expansão da assistência médica previdenciária. Na década de 1980, por outro lado, apesar das forças progressistas terem conseguido ampliar os direitos sociais e construir uma legislação avançada, baseada num entendimento bastante amplo da cidadania e do direito à saúde, só o fizeram por contemplar, no interior do seu projeto, as necessidades de maior racionalização e eficiência para os gastos no setor, fundamentais para que o Estado pudesse lidar com a "crise da dívida" e remunerar o capital portador de juros.

Nessa seção vimos como as políticas de saúde e os arranjos assistenciais que se desenharam na década de 1990 acabaram também por refletir tais contradições. Se por um lado ainda havia no país uma classe trabalhadora relativamente bem organizada, com os movimentos sociais (MST), organizações trabalhistas (CUT) e partidos políticos progressistas (PT) mantendo relevante capacidade de realizar a disputa política e ideológica, havia também a reorganização das classes proprietárias em torno do potente projeto neoliberal, representado tanto pelo seu componente ideológico, como também por sua grande influência nas políticas do Estado, bem exemplificadas pelos governos dos presidentes Fernando Collor de Mello, Itamar Franco e FHC.

A ofensiva neoliberal daquele período significava não somente uma ofensiva das classes proprietárias, no sentido de garantir maior poder econômico e politico (HARVEY, 2014), mas, no interior dessa ofensiva, refletia também a ascensão do capital portador de juros, ou como diria Chesnais (2010), "a proeminência da finança no seio do "capital em geral'". Como demonstrado por Paulani e Pato (2008) e abordado no capitulo 1 desse trabalho, as reformas do aparelho do Estado idealizadas e aplicadas nas décadas de 1990 e 2000 estavam tanto voltadas para minimizar o gastos em políticas sociais, como também para transformar o país em "plataforma de valorização financeira internacional". 
A partir da década de 1990, portanto, com o avanço do neoliberalismo enquanto projeto de Estado, os interesses da Finança ${ }^{82}$ tomam grande importância na definição das políticas de saúde. A partir dali exige-se que o mínimo possível seja aplicado pelo Estado na área (considerando-se a necessidade de garantir a estabilidade política e social), e que também seja maximizado o papel do orçamento do Estado na garantia da remuneração do capital portador de juros.

Os governos de Lula nos anos 2000 e Dilma, no começo da década de 2010, não representaram uma inflexão nesse processo. Ainda que a reforma neoliberal do aparelho do Estado tenha sido aplicada a um ritmo mais lento e negociado (pelo menos até o fim do primeiro governo Dilma), o sentido e direção das políticas de saúde mantiveram-se os mesmos (Teixeira e Pinto, 2012). Não foram realizados incrementos significativos no financiamento da saúde e não foram implementadas políticas que diminuíssem a estratificação do acesso ou que aumentassem de forma significativa o controle sobre o setor privado. Pelo contrário, investiu-se deliberadamente na construção da chamada "cidadania pelo consumo", em que o acesso a bens e serviços se dá cada vez menos por meio dos direitos e cada vez mais por meio do mercado.

Por todos esses anos, em que o imperativo foi o de garantir a máxima eficiência para os recursos aplicados pelo Estado em saúde, o investimento na APS ganhou uma grande importância. Abordaremos esse aspecto no capítulo seguinte.

82 Finança como definida por Duménil e Lévy (2010), ver Capítulo 1. 


\section{As Organizações Sociais na APS do município de São Paulo: notas críticas}

A construção do direito universal à saúde no Brasil, como vimos, se deu a partir de um sistema de saúde perdulário, insuficiente e desigual e sob pleno avanço da política e ideologia neoliberais. As reformas implementadas a partir do governo Collor, além de representar uma contraofensiva das classes proprietárias, estão relacionados ao novo papel que o país e seu Estado passariam a cumprir nessa fase contemporânea do capitalismo, de dominância do capital portador de juros, como "plataforma de valorização financeira internacional".

Num contexto de agravamento da crise estrutural de reprodução do capital e de hegemonia do capital portador de juros, o projeto da finança para o Estado brasileiro visava não só a desregulamentação e a liberalização dos fluxos de capitais, mas também reformá-lo para que cumprisse da forma mais efetiva possível, seu papel de remunerador do capital financeiro. Para que esse papel fosse cumprido da melhor forma possível, seria necessário que o mínimo de recursos fosse gasto com o restante de suas incumbências.

Esse projeto pode ser observado tanto nos documentos de uma das mais importantes instituições da finança internacional, o Banco Mundial (RIZZOTTO, 2012), como também nos documentos do próprio governo brasileiro, como o Plano Diretor da Reforma do Estado (PDRAE) (BRASIL, 1995), fortemente influenciado pelos mesmos princípios.

Nesse projeto, o Estado brasileiro deveria "diminuir de tamanho", terceirizando, ou simplesmente deixando a cargo da iniciativa privada, tudo que não fosse absolutamente essencial (nessa visão, só seria prerrogativa do Estado aquilo que dependesse do uso da força, como a defesa externa, a polícia e a justiça). Os gastos sociais deveriam ser focalizados, com recursos sendo aplicados somente naquelas áreas estritamente necessárias, e que trouxessem o maior resultado possível, no sentido de moderar os efeitos da pobreza e de seus possíveis efeitos políticos indesejados. Deveriam ser realizadas reformas que garantissem o livre fluxo de capitais e colocassem a remuneração do capital portador de juros como prioridade absoluta (ver seção 1.2.3). 
O projeto da finança, no entanto, não é o único projeto de reforma a disputar a conjuntura, assim como também não é aplicado sobre uma tábula rasa; incide sobre um Estado atravessado por interesses diversos, com profundas raízes históricas. Como discutido no capítulo anterior, os interesses das classes se expressam, na determinação da forma e das políticas do Estado, de maneira absolutamente complexa, com resultados dialéticos e contraditórios. Apesar dos muitos avanços experimentados pela política Neoliberal, não seria possível imputar a expressão concreta do Estado de hoje aos interesses de somente uma fração da classe burguesa.

Tendo toda essa complexidade em vista, e sem a pretensão de apontar todas as causas e consequências desse processo, discutimos nesse capítulo alguns elementos acerca da expressão concreta de parte desse projeto de reforma: a terceirização do serviços públicos de saúde na cidade de São Paulo por meio das Organizações Sociais.

Para realizar da melhor forma essa discussão, o capítulo está dividido em três seções. A primeira realiza breve descrição da Atenção Primária a Saúde (APS) no município de São Paulo, na sua relação com os modelos de gestão privatizantes. A segunda seção trata de alguns dos pressupostos do gerencialismo, como encontrados na reforma do aparelho do Estado dos anos 1990, e alguns elementos da situação atual do modelo das OS na cidade de São Paulo. A terceira seção discute alguns aspectos teóricos e práticos da relação entre o capital portador de juros e a terceirização dos serviços públicos, resgatando, sempre que possível, o caso específico do município de São Paulo.

\subsection{A Atenção Primária à Saúde no município de São Paulo}

Starfield (1994) define Atenção Primária à Saúde como uma modalidade ampla de cuidado oferecido a populações, sem que haja restrição por gênero, doença, ou órgão do corpo humano, sendo as características desse cuidado a abrangência, a longitudinalidade, a coordenação do cuidado e o primeiro contato (acesso). Apesar de essas características serem, em termos gerais, consenso na literatura, a concepção de APS, e, consequentemente, sua operacionalização, são bastante heterogêneas e historicamente tem sido alvo de disputas (GIOVANELLA; MENDONÇA, 2012). 
A internacionalização desse debate teve como marco a Conferência de Alma Ata, organizada em 1978 pela Organização Mundial de Saúde (OMS) e pelo Fundo das Nações Unidas para a Infância (Unicef). A Declaração de Alma Ata, documento síntese da conferência, demarcava a defesa da saúde como direito de todos e trazia a APS como forma prioritária de garantir a consecução desse direito:

Atenção essencial à saúde baseada em tecnologia e métodos práticos, cientificamente comprovados e socialmente aceitáveis, tornados universalmente acessíveis a indivíduos e famílias na comunidade por meios aceitáveis para eles e a um custo que tanto a comunidade como o país possa arcar em cada estágio de seu desenvolvimento, um espírito de autoconfiança e autodeterminação. É parte integral do sistema de saúde do país, do qual é função central, sendo o enfoque principal do desenvolvimento social e econômico global da comunidade. É o primeiro nível de contato dos indivíduos, da família e da comunidade com o sistema nacional de saúde, levando a atenção à saúde o mais próximo possível do local onde as pessoas vivem e trabalham, constituindo o primeiro elemento de um processo de atenção continuada à saúde. (UNICEF, 1979)

Apesar de um suposto consenso internacional acerca da centralidade da APS na organização de sistemas de saúde, as propostas e a concepção expostas na Declaração de Alma Ata passaram a ser alvos de críticas. Alguns organismos internacionais como o Banco Mundial, a Fundação Rockefeller, a Fundação Ford e a própria Unicef declararam que as medidas ali descritas seriam amplas demais e de difícil alcance e propuseram uma mediação, uma proposta que, a princípio, se constituiria apenas como tática temporária e complementar. Essa tática era a Atenção Primária à Saúde Seletiva, um conjunto de intervenções de baixo custo, direcionadas a um conjunto restrito de problemas de saúde, voltada principalmente para os países mais pobres, que não teriam recursos para implementar as medidas mais ambiciosas propostas por Alma Ata (LIMA, 2015). Como debatido na literatura (RIBEIRO, 2007; GIOVANELLA; MENDONÇA, 2012; LIMA, 2015), no entanto, essa estratégia pouco teve de provisória, se constituindo, na verdade, como projeto alternativo, amplamente propagado e executado em países periféricos do capitalismo.

Apesar da intensificação do debate acerca do modelo de APS que se observa a partir da década de 1970 , as características implícitas na proposta de APS Seletiva - programas de saúde focalizadores, determinados por interesses políticos e econômicos absolutamente estreitos - já vinham organizando a intervenção do Estado brasileiro na Saúde pública desde o seu início. A descrição das políticas 
públicas de saúde de São Paulo, a partir das características de sua rede básica, ilustra bem essa situação.

Como vimos no Capítulo 2, no entanto, a determinação das políticas de saúde é absolutamente atravessada pela dinâmica da luta de classes. A expressão real dessas políticas é nada menos do que o produto dialético e contraditório de suas disputas junto às estruturas do Estado. Se a rede de assistência à saúde e a APS paulistana de meados dos anos 2010 não faz jus aos direitos expressos na Constituição Federal de 1988, a partir dos quais a APS poderia cumprir papel decisivo para a construção de uma rede de saúde universal, equânime e integral, não é também a representação exata das políticas defendidas pelo Banco Mundial ou da APS Seletiva. A seguir discutiremos as características dessa rede nos períodos anteriores e posteriores à implementação do SUS.

\subsubsection{Antecedentes pré-SUS}

Como abordado no Capítulo 2, no Brasil, durante boa parte do século XX, os serviços públicos de saúde consistiam em estruturas verticalizadas, segmentadas por problemas de saúde, e voltadas principalmente para ações populacionais. A assistência individual ficava, na maioria das vezes, a cargo dos serviços previdenciários, de entidades filantrópicas, ou de serviços de acesso privado.

Apesar disso, existiram também serviços públicos com uma maior vocação assistencial, e até mesmo, em alguns aspectos, com orientação semelhante ao que hoje chamamos de APS. São exemplos os Centros de Saúde propostos por Paula Souza em São Paulo, na década de 1920, e os serviços da SESP, implantados nas bacias do Rio Doce e do Rio Amazonas, a partir da década de $1940^{83}$.

Segundo Mello et al (2011), apesar de a reforma da Saúde Pública proposta por Paula Souza não ter sido completamente implementada, os seus Centros de Saúde teriam influência duradoura na constituição da rede básica paulista. No estado, assim como no restante do país, o modelo dominante na saúde pública também foi o campanhista, que tinha como unidades mais básicas os dispensários unidades dedicadas a problemas específicos de saúde e voltadas para a prevenção,

83 Ambos, aliás, com forte influência estadunidense. Para uma discussão mais detalhada, ver Fausto (2005) e Ribeiro (2007). 
em ações comunitárias. Os Centros de Saúde propostos por Paula Souza em 1925, apesar de terem sido pensados para ações preventivas, também realizavam atendimentos individuais e eram voltados para a educação em saúde.

Em 1968, o secretário estadual de saúde Walter Leser, que teve Paula Souza como orientador em seu doutorado, resgata a importância dos Centros de Saúde, propondo que a eles fosse dado o papel de coordenação de uma rede básica e integrando-os aos dispensários. Se em âmbito nacional, a dicotomia entre prevenção (Saúde) e assistência (Previdência) se manteve até meados da década de 1970, com os Programas de Extensão de Cobertura, como o PIASS, no Estado de São Paulo, as reformas administrativas propostas por Leser já preparavam o terreno para uma maior integração. A partir de 1971, o CIAM (Centro de Integração de Atividades Médicas), convênio entre o INPS e a SES paulista, também já buscava alguma integração entre o sistema previdenciário e a saúde pública, com alocação de consultas da Previdência Social nas unidades públicas estaduais.

Se a reforma implementada pela SES paulista no final da década de 1960 já introduz alguns elementos administrativos e gerenciais para uma articulação entre os serviços, seria somente uma segunda reforma, realizada entre 1974 e 1979, que seria capaz de modificar o processo de trabalho, introduzindo consultas médicas programáticas como o foco principal dessas unidades. Nesse período teria sido também introduzida uma modalidade de pronto atendimento, com as consultas de pacientes "fora de dia", que antes inexistiam (RIBEIRO, 2007).

Portanto, ainda que a maior parte da assistência à saúde continuasse sendo realizada pelos serviços previdenciários, já começava a ser formar na década de 1970, no Estado de São Paulo, uma rede de serviços básicos, com algumas das atribuições semelhantes às dos serviços de APS. Essa rede de serviços básicos, no entanto, não consistia em porta de entrada ou articuladora de um sistema, mas em tática focalizadora, desarticulada da rede assistencial previdenciária e voltada para a cobertura daquelas populações social e economicamente mais vulneráveis.

A constituição dessa rede básica ganhou novo estímulo na primeira metade da década de 1980, com o Programa Metropolitano de Saúde (PMS). Em plena redemocratização, aumentavam as pressões da população por maior acesso a 
serviços de saúde, principalmente nas áreas periféricas da área metropolitana de São Paulo.

O PMS fora o principal resultante do "Projeto de Expansão dos Serviços Básicos de Saúde da Grande São Paulo", desenvolvido a partir de 1979 como corolário da pressão exercida por movimentos populares de saúde e diagnóstico da precariedade sanitária da região metropolitana. Dois anos depois é organizada a implantação do programa em cinco áreas priorizadas: Cotia, Mauá, Caieiras (municípios da Grande SP), Freguesia do Ó e Itaquera-Guaianazes (bairros periféricos do Município de SP). Os seguintes critérios foram observados: áreas periféricas carentes e com forte demanda popular por melhorias; locais em que a colaboração entre Estado, Município e Inamps já existisse; e áreas onde o novo modelo já estivesse em andamento, proporcionando uma implantação mais rápida e com menor investimento (caso da experiência de Cotia) (MELLO; IBAÑEZ; VIANA, 2011).

Seriam criados "módulos de saúde" que atenderiam entre 60 e 250 mil habitantes e que teriam a Unidade Básica de Saúde (UBS) como principal porta de acesso, contando também com o apoio de um hospital geral (SÃO PAULO (ESTADO), 1985). Projeto ambicioso, além de prever a construção de um grande número de UBSs e hospitais (SEIXAS, 2003, p. 123), o PMS buscava ampliar o acesso, por meio de um sistema integrado, hierarquizado e regionalizado. Estava previsto, portanto, que a rede básica dessas regiões atuasse como um verdadeiro nível de atenção, ou seja, essas UBSs funcionariam como unidades de APS.

Segundo Ibañez et al (2001, p. 395) e Seixas (2003, p. 171), já estava presente no PMS a possibilidade de colocar esses serviços sob gestão privada ${ }^{84}$. É importante notar aqui que já no segundo projeto de saúde financiado pelo Banco Mundial no Brasil| ${ }^{85}$, estavam presentes a focalização (implantação somente em áreas mais "carentes" e "com forte demanda popular"), a prioridade para os serviços de APS e a privatização da gestão dos serviços de saúde.

84 É curioso notar que boa parte dos textos acadêmicos que analisam as Organizações Sociais paulistas resgata o PMS, mas por um motivo diferente. Como a lei estadual de 1998 previa que somente novos serviços de saúde poderiam ser postos sob a administração das OS, os primeiros a serem colocados sob o novo modelo foram justamente os hospitais inacabados previstos pelo PMS, quando concluídos pelo Governo Covas (1995 - 2001) uma década mais tarde.

${ }^{85}$ Identificado dentre os empréstimos concedidos pelo Banco Mundial como "Cuidados Sanitários Básicos" (Soares, 2007), o PMS poderia, de certa forma ser considerado o primeiro projeto específico para a saúde financiado pelo Banco Mundial, com a concessão de aproximadamente U\$ 55 milhões. O empréstimo anterior dedicado à saúde (identificado pela sigla 2061 - BR e totalizando o valor de U\$ 13 milhões) estava vinculado a um projeto maior de infraestrutura chamado Polonoroeste, voltada para o desenvolvimento da região Noroeste do país (MARGULIS, 1991; RIZZOTTO, 2012). 
Além dos recursos do Banco Mundial, o programa contava também com recursos da Previdência Social. Como discutido no Capítulo 2, no contexto da "crise da previdência" e no intuito de garantir uma transição política sem sobressaltos, o governo federal também realizava esforços para ampliar a cobertura dos serviços de saúde e quebrar a dicotomia entre prevenção (Saúde) e assistência individual (Previdência). Com a criação das Ações Integradas de Saúde (AIS), o Inamps passava a realizar convênios com estados e municípios, como foi o caso do PMS. Apesar disso, enfrentando desde a falta de financiamento até problemas de ordem política, técnica e estrutural, o PMS nunca chegou a implementar completamente as mudanças a que se propunha, e acabou sendo abandonado pelos governos estaduais seguintes.

Já em 1987, com o Sistema Unificado e Descentralizado de Saúde (SUDS) considerado por alguns uma "estratégia-ponte" para o SUS e tentativa de integração dos serviços do Inamps numa rede de saúde pública integrada e universal - os governos estaduais e municipais começaram a assumir a coordenação da rede assistencial previdenciária. Sua implementação também provocou a ampliação da rede básica estadual. Segundo Cohn (1987), na constituição do SUDS, a "assistência médica de nível primário" deveria passar a cumprir papel importante no processo de integração, hierarquização e regionalização da assistência em saúde (COHN, 1987).

A implementação e a organização de um sistema público de saúde na maior cidade brasileira tem sido, no entanto, processo cheio de continuidades e descontinuidades. A articulação dessa rede básica enquanto nível de atenção e principal porta de entrada de um sistema de saúde devidamente integrado, hierarquizado e regionalizado não se deu com o PMS ou com o SUDS ${ }^{86}$. De certa forma, é ainda hoje tarefa a ser devidamente concluída.

\subsubsection{São Paulo na era SUS - A APS e as parcerias com o setor privado}

O primeiro governo municipal do período pós-1988 foi o de Luiza Erundina (1989-1992). Em um período de nascimento do SUS, em que a própria legislação

${ }^{86}$ Donnini (2003) ressalta que, enquanto no PMS havia alguma participação do governo municipal, na determinação conjunta com o governo do estado acerca do planejamento físico-territorial, o mesmo não era verdade no SUDS, em que o governo municipal ficou completamente alheio ao processo ( $p$. 32). 
federal ainda estava sendo formulada, o governo municipal tomou posição de vanguarda, com ações importantes já no primeiro ano de governo (1989), como a criação do Conselho Municipal de Saúde ${ }^{87}$ e também a pressão para que o Governo Estadual acelerasse o processo de municipalização (PATARRA, 1996). O governo Erundina apostou na descentralização, com a criação de 32 distritos de saúde, e na expansão da rede municipal - além dos serviços estaduais que foram municipalizados, houve também a construção de novos serviços. A contratação de profissionais também foi feita de maneira acelerada; entre 1989 e 1992, somente pela Secretaria de Saúde, 84 concursos para a contratação de novos profissionais foram realizados (BIANCARELLI, 1996).

Apesar desses avanços iniciais na implementação do SUS na cidade, os governos que se seguiram, de Paulo Maluf (1993-1996) e Celso Pitta (1997-2000) investiram em um modelo diferente, que manteve o município "fora do SUS" (PINTO; TANAKA; SPEDO, 2009). A criação do Plano de Atendimento à Saúde (PAS) a partir de 1995, com efetivo funcionamento a partir de 1996, motivou inclusive a suspensão de repasses federais para a saúde municipal (COHN; ELIAS, 1999).

Mais uma vez a administração municipal adotava posição de vanguarda, mas se antes o fazia na ampliação dos serviços e no estímulo à participação popular, dessa vez o fazia na aplicação do receituário neoliberal, com a criação de novos "modelos de gestão" para a saúde pública (ELIAS, 1999). O PAS foi formulado a partir de estudo realizado pela FIPE sobre o SUS, encomendado pela Secretaria Municipal do Planejamento e concluído no início de 1995. Com inspiração explícita nas recomendações do Banco Mundial para a saúde ${ }^{88}$, o documento apontava a gestão estatal dos serviços de saúde como um dos principais problemas do sistema de saúde brasileiro, sendo necessário, segundo o documento, delegar a prestação dos serviços à iniciativa privada. No modelo proposto os serviços de saúde seriam providos por cooperativas de profissionais de saúde, que competiriam entre si pela clientela num ambiente de mercado.

O projeto aprovado, no entanto, acabou não contemplando a competição entre as cooperativas. A cidade foi dividida em 14 regiões (Módulos de Atendimento

${ }^{87}$ Em junho 1989, antes portanto da Lei no 8.142, de 28 de dezembro de 1990, que regulamenta a participação popular através dos conselhos.

${ }^{88}$ Ver mais em "Proposta de um novo modelo para a saúde" (FIPE, 1995). 
Básico), que deveriam ser compostos por ao menos uma unidade de pronto-socorro, uma unidade hospitalar e pelos postos de atendimento à saúde (antigas UBSs). No convênio firmado, a prefeitura se obrigava a fornecer as instalações, equipamentos e recursos financeiros necessários para a prestação dos serviços de saúde, enquanto as cooperativas deveriam fornecer os recursos humanos necessários e gerir o processo de trabalho. Parte dos trabalhadores municipais da saúde seria cedida a duas cooperativas (COOPERPAS e COOPERMED) ${ }^{89}$ e, se necessário, profissionais não pertencentes aos quadros da administração municipal poderiam ser contratados por meio da contratação dos serviços de outras cooperativas ${ }^{90}$. Segundo Donnini (2003), os módulos cooperativados eram bastante desarticulados entre si, e havia pequena capacidade de intervenção programática e gerencial por parte da Secretaria Municipal de Saúde (SMS) (p. 36). Ainda segundo o autor, foi adotado, para o PAS, um modelo de pré-pagamento per capita, o que poderia estimular, como maneira de alcançar superávits, uma maior restrição da qualidade e quantidade da assistência por parte das cooperativas.

Para Cohn e Elias (1999), o PAS configurava-se como uma:

"transferência da produção estatal dos serviços de saúde para o setor privado não lucrativo. Seu traço essencial é representado pelo incremento do grau de autonomia dos agentes prestadores de serviços no que se refere à administração e à organização do trabalho, uma vez que o modo de gerenciamento dos serviços de saúde passa a se dar segundo parâmetros dos serviços privados. [...] É necessário, porém, sublinhar que destes elementos constitutivos do PAS, apenas a autonomia dos agentes prestadores de serviços se efetivou no cotidiano das unidades, uma vez que a regulação pelo mercado - representada pela competição entre as cooperativas - e a racionalização dos serviços em moldes capitalistas com vistas à diminuição de gastos estão longe de serem incorporadas pelo desempenho do Plano" (COHN; ELIAS, 1999, p. 106)

Para os autores, o arranjo da "parceria" poderia ser considerada uma terceirização:

"ocorre uma transferência da autonomia administrativa e gerencial na produção dos serviços de saúde para o setor privado, mais identificada com as modalidades conhecidas como "terceirização de serviços" (neste caso bastante ampliada, dadas as inúmeras atividades e setores

89 Esses servidores municipais eram estimulados, na verdade, a solicitar uma licença sem vencimentos do serviço público para que fossem contratados, por um salário maior, pelas cooperativas. Para mais detalhes, ver Junqueira (2002).

90 Ao final do governo Pitta (1997-2000), havia cerca de 5 mil servidores municipais cedidos às cooperativas e cerca de 12 mil cooperados não servidores municipais (SOUSA; MENDES, 2003, p. 35). 
envolvidos nesse processo de transferência), do que propriamente com a transferência envolvendo poder decisório e a responsabilidade do Estado no provimento dos serviços de saúde. [...] Vale dizer, em se tratando do PAS, que constitui aspecto estratégico dos mais relevantes a transferência para o setor privado apenas da produção dos serviços de saúde, permanecendo seu financiamento integralmente dependente dos fundos públicos geridos pelo Estado, segundo os padrões impostos pela administração municipal. [...] Portanto, essa concepção atende integralmente os parâmetros apresentados como desejáveis pelos organismos internacionais para a implantação das políticas de saúde nos países em desenvolvimento, configurando-se também como uma proposta descentralizadora em benefício da privatização de parcela das atividades anteriormente sob responsabilidade da Prefeitura" (COHN; ELIAS, 1999, p. 107-8).

Como bem observaram os autores em outro trecho de seu trabalho (p. 98), as mesmas diretrizes que orientavam o PAS estavam também presentes na proposta, do governo federal de então, de Organizações Sociais. Enquanto os trechos acima descrevem a situação da organização dos serviços de saúde sob o PAS, na segunda metade da década de 1990, poderiam também descrever a situação atual, em que a produção privada dos serviços de saúde é realizada pelas Organizações Sociais, em vez das cooperativas. Junqueira (2002) descreve situações ainda mais graves, mas que também encontram paralelo no modelo atual das OSs, como a seleção adversa da clientela, situação em que há a seleção dos usuários que apresentem menor risco e que gere melhores indicadores de saúde ${ }^{91}$ (JUNQUEIRA, 2002, p. 42-3).

Além do descrito acima, há outra característica em comum entre as duas experiências que deve ser ressaltada, que é a sua relação desses modelos de gestão com as instâncias de controle social. Na vigência do PAS, o Conselho Municipal de Saúde, foi, de facto, abolido, tendo sido instituído em seu lugar um colegiado menos "político" (COHN; ELIAS, 1999, p. 155), o Grupo de Representantes de Usuários do PAS (GRUPAS). Na atuação desse colegiado, o mais importante não teria sido uma "gestão democrática" dos serviços de saúde, mas sim um "bom gerenciamento da cooperativa" (COHN; ELIAS, 1999, p. 149). Avaliando não somente a atuação desse colegiado, mas também o desempenho dos outros mecanismos de controle, os autores concluem que não havia uma preocupação, por parte dos gestores do PAS, "em implantar um programa de

${ }^{91}$ Ver na próxima seção a discussão sobre essa e outras distorções na atuação das OS. 
controle voltado para o atendimento das necessidades de saúde da população que propiciasse a eficiência e a eficácia do Plano" (COHN; ELIAS, 1999, p. 176).

Persistem diferenças importantes, no entanto. O PAS não implementava todas as recomendações do Banco Mundial, era uma versão incompleta. Apesar de apresentar orientação explicitamente focalizadora ${ }^{92}$ e de ter sido radical na privatização da produção dos serviços de saúde, (a ponto do Governo Federal de FHC, que criou o MARE, cortar-lhe os repasses financeiros), deixava a desejar na reorientação da rede em função da APS; com o PAS, cessaram inclusive os esforços de municipalização da rede básica estadual.

Nessa mesma época, particularmente em 1994, o governo federal criava o Programa Saúde da Família (PSF), na tentativa de expandir a rede básica do SUS. Como o PAS propiciara o rompimento do governo municipal para com o Ministério da Saúde, coube ao governo estadual levar a cabo o projeto na capital. Em 1996, mesmo ano em que o PAS entrava em operação, foi criado pelo governo estadual o Projeto Qualidade Integral em Saúde (Qualis).

O projeto Qualis deu as bases para a configuração atual do PSF na cidade de São Paulo, parte mais importante da APS municipal e principal objeto da nossa análise.

Segundo Silva Guedes et al (2011), a princípio, "o Ministério da Saúde, a Secretaria Estadual da Saúde e a entidade filantrópica Casa de Saúde Santa Marcelina (CSSM) estabeleceram parceria para efetivar o PSF no município" (p. 879). O convênio com a CSSM foi chamado de "Qualis I", e teria sido uma espécie de laboratório do modelo. Campos e Malik (2008) o descrevem assim:

"O modelo de convênios utilizado era uma parceira entre a Secretaria de Estado da Saúde, o Ministério da Saúde e entidades filantrópicas ligadas à prestação de serviços na área da saúde - fundações e organizações sociais. A justificativa das parcerias partiu de uma avaliação da secretaria, segundo a qual o gerenciamento dos serviços por meio de organizações sociais e fundações possibilitaria maior agilidade gerencial e administrativa ao programa. Segundo o modelo proposto, os parceiros assumiam integralmente $\mathrm{o}$ projeto, com uma equipe central encarregada do

92 Sobre isso relatam Cohn e Elias (1999): "Contrário à implantação do SUS no município, um vereador da situação faz a defesa do PAS afirmando que o acesso universal não funciona na prática, uma vez que o acesso ao SUS é muito restrito, dado o modelo de gerenciamento vigente ser impraticável. E prossegue destacando que, em contrapartida, o PAS destina-se às pessoas que estão sem atendimento..." (p. 39). 
planejamento, da supervisão e da avaliação do programa. Juntamente com a secretaria, os parceiros identificaram as áreas de implantação das equipes, realizaram a contratação da equipe técnica e dos agentes comunitários de saúde, assim como o processo de capacitação. Os projetos foram totalmente financiados com recursos públicos. Às instituições parceiras cabia a responsabilidade pelo gerenciamento dos recursos, o provimento do material de consumo, contratação de pessoal e a operacionalização das equipes do Programa de Saúde da Família. Os profissionais eram contratados em regime da Consolidação das Leis do Trabalho, que regulamenta o setor privado e a seleção foi realizada por meio de análise de currículo e entrevistas" (CAMPOS; MALIK, 2008, p. 351).

No ano seguinte, 1997, foi realizado o segundo convênio (Qualis II), com a Fundação Zerbini e, em 2000, foram realizados convênios com mais duas instituições, a Universidade Santo Amaro (Unisa) e a Associação Congregação Santa Catarina (SILVA GUEDES; SANTOS; LORENZO, 2011). Desde a primeira experiência para a implantação do PSF em São Paulo, com o Qualis, já se estabeleceu, portanto, o modelo de "parcerias" com entidades de direito privado, como instituições filantrópicas e fundações de apoio, para a contratação de profissionais e a gestão dos serviços. É importante observar que, muito embora o convênio realizado entre o Ministério da Saúde, a SES e as "instituições parceiras" para a criação do Qualis guarde diferenças importantes para com o PAS (como o foco na criação de serviços básicos e a maior atenção à formação dos profissionais), ambos se caracterizam pela contratação e gestão privada dos serviços públicos de saúde. Ambos os projetos estavam, portanto, em conformidade com as políticas para o setor propagandeadas e financiadas por instituições financeiras internacionais como o FMI e o Banco Mundial, e também estavam em consonância com as reformas do Estado implementadas pelo governo federal de então.

Em 2001 inicia-se o governo municipal de Marta Suplicy (2001-2004) e, com o fim do PAS, reinicia-se o processo de municipalização da rede. Apesar de apresentar uma retórica que defendia a publicização e a democratização dos serviços de saúde, o governo da "frente democrático-popular" manteve e ampliou a realização de convênios para a implementação do PSF (JUNQUEIRA, 2002; SOUSA; MENDES, 2003).

O primeiro secretário de saúde desse governo colocava a construção do PSF no município como uma das principais prioridades daquela gestão (SOBRINHO, 2003a), enquanto apontava para a parceria com outras instituições, tanto de ensino 
como de assistência, como fundamental para alcançar esse objetivo (SOBRINHO, 2003b). Sousa (2003) coloca essa escolha nos seguintes termos:

"A Secretaria Municipal de Saúde da cidade de São Paulo, quando assumiu a tarefa de instituir desde janeiro de 2001, o Programa Saúde da Família - PSF como a estratégia para reorganizar a Atenção Básica à Saúde, sentiu e entendeu que não poderia realiza-la sozinha. [...] Essa foi, indubitavelmente, uma decisão firme de co-responsabilizar a instalação do PSF no município de São Paulo com os cidadãos e cidadãs que compartilhavam os mesmos objetivos: garantir aos paulistanos o direito à saúde, e esta, com qualidade" (p. 91).

Assim como Sousa (2003), Inojosa (2003) descreve as parcerias com essas instituições nos termos de uma maior participação da comunidade, em argumento semelhante ao utilizado por Bresser Pereira no PDRAE (BRASIL, 1995). A hipótese que se apresenta nesse trabalho, no entanto, é que a cessão da gerência desses serviços públicos para entidades de direito privado, como as Organizações Sociais, não representou, até agora, nem maior participação da comunidade e nem o fortalecimento do interesse público na consecução das políticas sociais. Tal hipótese é discutida mais detalhadamente na seção 3.2.2.

O governo Marta Suplicy (2001-2004), tinha, portanto, a construção do PSF como principal vetor para a expansão da APS e para a reorganização da rede municipal de assistência à saúde - expansão que seria realizada através das parcerias com instituições do direito privado. Ao inicio da gestão, encontrara uma cobertura do PSF na cidade de aprox. 5,5\% (toda composta por unidades do Qualis), e estabeleceu uma meta de, em quatro anos, alcançar $60 \%$ da população. Apesar da meta ambiciosa, em dezembro de 2004 a cobertura do PSF em São Paulo era estimada em apenas 20\% (PINTO; TANAKA; SPEDO, 2009, p. 933).

O governo seguinte (2005-2008), de José Serra (sucedido posteriormente por Gilberto Kassab), manteve as parcerias para a manutenção e expansão dos serviços de APS. Segundo Pinto et al (2009) a gestão Serra-Kassab continuou a expandir a rede de PSF por meio de parcerias, porém em um ritmo mais lento. Além disso, teria privilegiado a expansão do PSF em regiões em que já existiam as chamadas "UBSs tradicionais", criando unidades "mistas". Nessas unidades mistas, as equipes de PSF, contratadas pelas instituições parceiras, dividiam o mesmo espaço com servidores públicos estatutários, que atuavam em equipes com clínicos, pediatras e ginecologista-obstetras. 
As unidades de pronto atendimento criadas pelo governo Serra-Kassab, chamadas de AMAs (Atendimento Médico Ambulatorial), também utilizaram, muitas vezes, as estruturas já existentes de unidades do PSF e de UBSs tradicionais. O mesmo aconteceu com os ambulatórios de especialidades criados nesse governo, as AMAs Especialidades (CORSALETTE, 2008; FOLHA DE SÃO PAULO, 2008).

Pinto et al (2009) ressaltam que a partir de 2005 haveria um aprofundamento das parcerias:

Portanto, apesar das distintas orientações político-partidárias das gestões estudadas, observou-se que a terceirização de serviços e de estabelecimentos de saúde esteve presente desde o início da primeira gestão, inicialmente centrada no gerenciamento de pessoal para o PSF e na contratação de serviços de apoio diagnóstico. Na segunda gestão, constatou-se um aprofundamento dessa política, chegando à terceirização da gerência de estabelecimentos e até mesmo de regiões de saúde (PINTO; TANAKA; SPEDO, 2009, p. 936).

Além de aumentar as atribuições das parceiras, foi também nesse período que avançou o modelo jurídico de sua contratação. Apesar das leis federal e estadual datarem de 1998, até então, no âmbito municipal, as parcerias eram celebradas na forma de convênio. Seria somente em janeiro de 2006 que seria aprovada a lei municipal $n^{0} 14.132$, que regularia os contratos entre a prefeitura e as Organizações Sociais. O primeiro Contrato de Gestão do Município de São Paulo com uma Organização Social para a área da saúde foi firmado em 2007 (ORLANDO, 2012).

Como notam Contreiras e Matta (2015), no entanto, mesmo após um longo período decorrido da aprovação da lei municipal das OS e da assinatura do primeiro contrato de gestão, a Prefeitura Municipal de São Paulo (PMSP) mantinha um grande número de convênios para a prestação de serviços de saúde. Segundo os autores, em 2010, dentre os 936 estabelecimentos da rede municipal de saúde, 61\% estavam sob gestão privada; $36 \%$ cedidas na forma de convênio e somente $25 \%$ sob a gestão de OS (CONTREIRAS; MATTA, 2015, p. 289). Mas essa situação não perdurou somente até 2010, passados mais de 10 anos da aprovação da lei municipal das OS, persistem os convênios. A Portaria № 2373/2015-SMS.G, republicada em 30 de dezembro de 2015, prorrogou para 30 de junho de 2016 a vigência dos convênios com 14 entidades, somente nos serviços sob a Coordenação 
da Atenção Básica (SECRETARIA MUNICIPAL DE SAÚDE DE SÃO PAULO, 2015a).

Contreiras e Matta (2015) ressaltam que muito embora a regulação e a fiscalização das OS apresentem diversos problemas, a situação é ainda mais grave com relação aos convênios. Os autores questionam os motivos de se manter durante tantos anos um grande número de parcerias que apresentam um grau mais alto de discricionariedade, e apontam que os motivos para tal situação não são meramente "técnicos":

No entanto, a desregulação também deve ser entendida como resultado de uma negociação política entre diversas partes. As alterações no marco legal estadual que reverteram antigas restrições à atuação das OS, com destaque para a reserva de leitos públicos para a medicina privada, tornam evidente o alcance do interesse privado e o fato de que a discussão das OS vai além do técnico. Além disso, como visto, entre as entidades parceiras da prefeitura estão cinco das dez maiores empresas do Brasil no ramo de serviços médicos. Ou seja, mais do que um campo de desinteressada filantropia ou a representação de uma difusa e autoorganizada sociedade civil, o terceiro setor é um campo de fortíssima atividade econômica. Se não gera lucros diretamente, gera receita, superávit, expansão, concentração e poder - e, com isto, interesses particulares. Portanto, a fragilidade regulatória da administração municipal, em uma perspectiva política, pode também ser entendida como resultado de sua permeabilidade ao interesse privado em um contexto de oposição atenuada (CONTREIRAS; MATTA, 2015, p. 295).

$\mathrm{Na}$ área da saúde, a segunda gestão municipal de Gilberto Kassab (20092012) manteve as linhas gerais do seu primeiro governo. Manteve as parcerias com OS e "OS símiles" e o investimento nas AMAs. As AMAs, aliás, foram criadas enquanto unidades básicas que não fariam o acompanhamento longitudinal, somente o pronto atendimento. Enquanto o discurso oficial do governo as defendia enquanto alternativa para aliviar, os prontos-socorros dos hospitais mais bem equipados, da pressão assistencial de atender também os casos de menor gravidade, o projeto parecia resgatar a velha dicotomia "assistência x prevenção", deixando o pronto atendimento com as AMAs e o cuidado programático com as UBSs.

Segundo Contreiras e Matta (2015), a maioria (61\%) dos estabelecimentos de saúde municipais estavam sob gestão privada em 2010, mas o número era ainda 
mais expressivo na "Atenção Básica", em que convênios e OS administravam $72 \%$ da rede ${ }^{93}$.

O número de trabalhadores contratados por meio de convênios e OS aumentou de forma bastante expressiva no período dos governos de Serra e Kassab (2005 a 2012). O número de funcionários públicos se manteve relativamente estável no período, indo de 27.225 trabalhadores em 2004 para 26.198 em 2012, enquanto isso, o número de trabalhadores contratados por meio dos convênios (e a partir de 2007, também pelas OS) foi de 8.073 em 2004 para 38.351 em 2012, um aumento de $375 \%$ (SECRETARIA MUNICIPAL DE SAÚDE DE SÃO PAULO, 2012).

$\mathrm{Na}$ eleição municipal de 2012, os dois principais candidatos se envolveram em escaramuças que tinham como tema a terceirização dos serviços de saúde. $A$ campanha de José Serra acusava o adversário de querer acabar com as parcerias, Fernando Haddad negava a acusação e prometia avanços na fiscalização e controle (AGENCIA ESTADO, 2012; MATTOS, 2012).

A gestão Haddad (2012-2016) realmente não encerrou as parcerias, e tomou iniciativas para aumentar o controle da SMS, ao aumentar os mecanismos de controle e avaliação dos novos contratos ${ }^{94}$.

O Contrato de Gestão proposto pela prefeitura no chamamento público para a seleção de organização social para o gerenciamento e execução das ações e serviços de saúde na região do Butantã, realizado em 2015, prevê até mesmo que tipo de investimento financeiro a Organização Social poderá realizar com os recursos não utilizados, mecanismo que não é encontrado no Contrato de Gestão de 2008 para a mesma região:

"Os recursos pagos à CONTRATADA, enquanto não utilizados, deverão ser por esta aplicados em cadernetas de poupança se a previsão de seu uso for igual ou superior a 1 (um) mês, ou em fundo de aplicação financeira de curto prazo ou operação de mercado aberto lastreada em títulos da dívida pública, quando a sua utilização verificar-se prazos menores do que 1 (um) mês, eximindo a CONTRANTE dos riscos

${ }^{93}$ Sobre isso escrevem os autores: "em 2010, $61 \%$ dos 936 estabelecimentos da rede municipal de saúde estavam sob gestão privada, com predomínio de entidades conveniadas OS símiles (36\% contra $25 \%$ sob gestão de OS). Desagregando a rede por setores, tem a gestão privatizada $72 \%$ da atenção básica, $59 \%$ dos hospitais, $40 \%$ dos ambulatórios especializados e $1 \%$ do restante da rede" (CONTREIRAS; MATTA, 2015, p. 289) 
assumidos nestas aplicações" (SECRETARIA MUNICIPAL DE SAÚDE DE SÃO PAULO, 2015b).

Além disso, apresenta um maior número de instrumentos de avaliação e controle do que o Contrato de Gestão anterior, assinado em 2008. (SECRETARIA MUNICIPAL DE SAÚDE DE SÃO PAULO, 2008; 2015b).

Entre 2014 e 2015, os gastos da SMS com os convênios e Contratos de Gestão aumentaram cerca de 3,6\% - de aproximadamente $R \$ 2,99$ bilhões para $R \$$ 3,11 bilhões, sendo o gasto total da prefeitura em saúde pública de aproximadamente $R \$ 6,58$ bilhões, em 2015. A proporção desse valor gasto com os convênios, em vez de Contratos de Gestão (OS), caiu de 44\% para 28\% (SECRETARIA MUNICIPAL DE SAÚDE DE SÃO PAULO, 2016), o que reflete a conversão de alguns convênios em Contratos de Gestão. Apesar da diminuição, manteve-se um grande número de parcerias no formato de convênios, modalidade que, como discutido anteriormente, apresenta menor quantidade de instrumentos de controle e menor transparência.

Outra mudança buscada pela gestão Haddad foi a divisão da cidade em 18 territórios, e a organização de chamamentos públicos para a celebração de Contratos de Gestão que permitissem a contratação de uma única OS para cada território (PREFEITURA MUNICIPAL DE SÃO PAULO, 2014). Apesar das medidas prometerem menor fragmentação da rede municipal e maior controle por parte da SMS, em algumas regiões da cidade o processo de mudança da instituição parceira envolveu diminuição da equipe de assistência e descontinuidade do serviço. $\mathrm{Na}$ região do Butantã, dezenas de trabalhadores demitidos denunciaram que a nova OS contratada para gerir os serviços de saúde na região oferecia salários até $73 \%$ menores para a mesma função (JORNAL DO SIMESP, 2016; SPTV 1a EDIÇÃO, 2016).

Ainda que a SMS e a PMSP neguem qualquer responsabilidade por episódios como esse (SPTV 1a EDIÇÃO, 2016; SECRETARIA MUNICIPAL DE SAÚDE DE SÃO PAULO, 2016), tratando essas situações como meros "acidentes de percurso", é uma hipótese desse trabalho que tais acontecimentos não tem nada de acidentais, mas exemplificam, na verdade, alguns dos motivos centrais pelos quais a prefeitura recorre à terceirização de seus serviços. A seção a seguir discutirá um pouco mais sobre a atuação das OS na cidade de São Paulo. 


\subsection{O gerencialismo como paradigma para a gestão dos serviços de saúde}

Marco institucional da reforma do Estado brasileira, o Plano Diretor da Reforma do Aparelho do Estado (BRASIL, 1995) é o documento que introduz institucionalmente o conceito de Organizações Sociais. O documento estabelece os argumentos técnicos e políticos que serão utilizados nas disputas legislativas e jurídicas que se seguiriam

Nesse documento base para as reformas do Estado brasileiro, estabelece-se que o aparelho do Estado deveria ser dividido em quatro setores: núcleo estratégico ${ }^{95}$; atividades exclusivas ${ }^{96}$; serviços não-exclusivos; e produção de bens e serviços para o mercado $^{97}$.

Os serviços de saúde são enquadrados na categoria dos serviços nãoexclusivos, que são definidos nos seguintes termos:

"Corresponde ao setor onde o Estado atua simultaneamente com outras organizações públicas não-estatais e privadas. As instituições desse setor não possuem o poder de Estado. Este, entretanto, está presente porque os serviços envolvem direitos humanos fundamentais, como os da educação e da saúde, ou porque possuem "economias externas" relevantes, na medida que produzem ganhos que não podem ser apropriados por esses serviços através do mercado. As economias produzidas imediatamente se espalham para o resto da sociedade, não podendo ser transformadas em lucros. São exemplos deste setor: as universidades, os hospitais, os centros de pesquisa e os museus" (BRASIL, 1995, p. 41-2)

O documento elenca dois modelos "relevantes" para a administração pública: o modelo burocrático, e o modelo gerencial. O modelo burocrático sofreria de um excesso de formalismo e de uma ênfase excessiva no controle dos processos, porém apresentaria como vantagens a segurança e a efetividade das decisões (BRASIL, 1995, p. 43). A administração gerencial, por outro lado, "caracteriza-se

95 Definido no documento assim: "É o setor que define as leis e as políticas públicas, e cobra o seu cumprimento. É portanto o setor onde as decisões estratégicas são tomadas. Corresponde aos Poderes Legislativo e Judiciário, ao Ministério Público e, no poder executivo, ao Presidente da República, aos ministros e aos seus auxiliares e assessores diretos, responsáveis pelo planejamento e formulação das políticas públicas" (BRASIL, 1995, p. 41)

96 "É o setor em que são prestados serviços que só o Estado pode realizar. São serviços em que se exerce o poder extroverso do Estado - o poder de regulamentar, fiscalizar, fomentar" (BRASIL, 1995, p. 41)

97 "Corresponde à área de atuação das empresas. É caracterizado pelas atividades econômicas voltadas para o lucro que ainda permanecem no aparelho do Estado como, por exemplo, as do setor de infra-estrutura. Estão no Estado seja porque faltou capital ao setor privado para realizar o investimento, seja porque são atividades naturalmente monopolistas, nas quais o controle via mercado não é possível, tornando-se necessário no caso de privatização, a regulamentação rígida" (BRASIL, 1995, p. 42). 
fundamentalmente pela eficiência dos serviços prestados a milhares senão milhões de cidadãos" (BRASIL, 1995, p. 43-4).

O núcleo estratégico deveria adotar um misto dos dois modelos, enquanto os três setores restantes deveriam adotar o modelo gerencial:

"No setor das atividades exclusivas e de serviços competitivos ou não exclusivos, o importante é a qualidade e o custo dos serviços prestados aos cidadãos. O princípio correspondente é o da eficiência, ou seja, a busca de uma relação ótima entre qualidade e custo dos serviços colocados à disposição do público" (BRASIL, 1995, p. 43).

Ainda segundo o documento, a melhor maneira para aplicar o modelo gerencial ao setor de serviços não-exclusivos seria delegá-lo a um setor "público não-estatal", composto pelas Organizações Sociais, que celebrariam Contratos de Gestão com o Poder Executivo. As maiores "autonomia" e "responsabilidade" logradas às OS permitiriam que os serviços fossem mais bem executados sob dois aspectos chave: seriam submetidos a um maior controle social; e gozariam de maior qualidade e eficiência.

Desde a implementação das OS em São Paulo, o modelo tem sido motivo de grande debate, e tem sido avaliada tanto a sua capacidade de imprimir maior eficiência aos serviços de saúde (IBAÑEZ et al., 2001; FERREIRA JUNIOR, 2003; BARBOSA; ELIAS, 2010), como também a sua capacidade de se submeter aos controles públicos (NASSUNO, 1999; SANO; ABRUCIO, 2008; CONTREIRAS; MATTA, 2015).

A seguir discutiremos ambas as questões a partir da experiência concreta de sua aplicação na cidade de São Paulo. A seção 3.2.1 discute a questão da qualidade e eficiência supostamente propiciadas pelo modelo. A questão do Controle Social, e também a participação dos trabalhadores, será discutida na seção 3.2.2.

\subsubsection{Eficiência e Qualidade}

Alguns estudos analisaram, no âmbito estadual, os serviços submetidos à gestão das OS e apontaram um ganho de eficiência desses serviços quando comparados a serviços de Administração Direta (AD). São exemplos importantes aqui, dois estudos financiados pelo Banco Mundial: Medici e Murray (2010) 
apontaram vantagens no que se refere à taxa média de ocupação e à taxa média de permanência por leito, apresentando custos menores; Costa e Ribeiro (2004) apresentaram resultados semelhantes, apontando também menor taxa de mortalidade geral.

Em análise menos criteriosa, Orlando (2012) aponta que, no âmbito municipal, as OS eram responsáveis por $75 \%$ das consultas médicas, enquanto recebiam apenas $39 \%$ do orçamento ${ }^{98}$.

Tais estudos podem parecer, à primeira vista, evidência incontornável do melhor desempenho das OS, mas é necessário aqui realizar uma análise mais criteriosa desses processos.

Estudos como os de Goddard et al (1998) e o de Mannion e Braithwaite (2012) descrevem, a partir da experiência do National Health Service (NHS) inglês, algumas distorções que podem emergir da aplicação de indicadores de desempenho (metas) aos serviços de saúde,:

O impacto de um sistema de medição de desempenho vai depender das recompensas, punições e incentivos implícitos na sua concepção. Em um extremo, se nenhum incentivo adequado é posto em prática, os dados produzidos podem ser largamente ignorados e não produzir qualquer ação significativa. No outro extremo, a subsistência dos gestores e profissionais de saúde pode depender crucialmente de medidas relatadas, levando ao potencial de atenção excessiva ao desempenho relatado (em oposição ao resultado do paciente) e falsas declarações (tradução nossa, GODDARD; MANNION; SMITH, 1998, p. 158).

Para Mannion e Braithwaite (2012), os "efeitos colaterais" resultantes da aplicação de incentivos financeiros ou punições podem ser agrupados em quatro grupos: medição ruim (poor measurement); incentivos e sanções mal aplicadas (misplaced incentives and sanctions) ${ }^{99}$; quebra de confiança (breach of trust); e politização dos sistemas de performance (politicisation of performance systems) ${ }^{100}$.

98 O texto de Orlando (2012) faz parte de uma espécie de divulgação das realizações das gestões municipais de 2005 a 2012 (Serra e Kassab). A descrição dos avanços unicamente a partir da análise do número de serviços de saúde e do número de consultas ilustra, de certa forma, a discussão realizada nessa seção acerca da atenção exacerbada dispensada a metas quantitativas.

${ }^{99}$ Refere-se às situações nas quais os incentivos e sanções não cumprem a função esperada, de melhora da qualidade e eficiência dos serviços, podendo ser responsáveis pelo aprofundamento de desigualdade entre os serviços ou até mesmo tendo efeito oposto ao esperado, desestimulando o desempenho.

100 Refere-se à criação de metas, ou à realização de sua análise, com o objetivo de propiciar aos governos a divulgação de resultados exageradamente ou falsamente positivos. 
De forma resumida, descreveremos somente algumas das distorções relacionadas à "medição ruim" e à "quebra de confiança", mais relevantes para a nossa discussão em tela. Iniciaremos por destacar algumas daquelas relacionadas à medição dos indicativos:

- measurement fixation, que ocorre quando a ênfase é colocada em alcançar a meta em si, e não naquilo que a motivou:

"Um alvo de 5 minutos de espera na emergência de hospitais de urgências no NHS foi criado para promover arranjos de triagem mais oportunos e eficazes, mas levou ao emprego, em alguns hospitais, de 'enfermeiras-olá'. Elas apenas fazem contato com o paciente nos primeiros 5 minutos com o objetivo 'completar a tarefa', e atingir superficialmente a meta de desempenho" (tradução nossa, MANNION; BRAITHWAITE, 2012, p. 570);

- tunnel vision, no qual os incentivos para que o serviço realize melhor algumas tarefas pode acarretar o negligenciamento de outros aspectos não medidos, mas igualmente importantes;

- myopia, no qual a busca por alcançar metas de curto prazo pode acabar tendo uma repercussão negativa a longo prazo;

- ossification, no qual a busca por indicadores de performance (desempenho) pode engessar o serviço;

- anachronism, se refere ao fato de que as variáveis medidas podem se referir a uma situação passada, que não mais representa a situação do presente;

- quantification privileging:

"diz respeito à preocupação com a redução de fenômenos sociais complexos a números, e a consequente perda da valorização dos aspectos qualitativos ou "mais leves" do cuidado em saúde, que podem ser perdidas ou minimizadas nas avaliações. Muitos fatores importantes que afetam o desempenho são qualitativos, tais como a cultura, o moral dos trabalhadores e as experiências dos pacientes. Estes não são facilmente quantificáveis, e mesmo quando eles são, por exemplo, através da aplicação de escalas de atitude, eles têm uma dimensão qualitativa que pode ser desperdiçada" (MANNION; BRAITHWAITE, 2012, p. 571, tradução nossa).

O estudo de Goddard et al (1998), aponta, além de algumas das categorias descritas acima, outra distorção relacionada à medição: 
- fragmentation, no qual serviços dedicados a perseguir suas próprias metas podem ter menor propensão a colaborar com o restante da rede.

Além das distorções relacionadas à medição dos indicativos, destacaremos abaixo também algumas das situações relacionadas à "quebra de confiança", descritas por Mannion e Braithwaite (2012):

- misrepresentation, é manipulação deliberada dos dados, pelos trabalhadores ou pela gerência, em situações que podem variar da "contabilidade criativa" até a mera fraude;

- gaming, é quando, em uma situação na qual os incentivos são relacionados ao ganho de desempenho ano a ano, alguns trabalhadores ou gestores acabam alcançando, propositalmente, resultados menores no ano presente para que suas metas em anos futuros sejam mais fáceis de serem alcançadas.

- reduced staff morale: é quando os trabalhadores se sentem injustiçados nas avaliações realizadas, acabando por perder o moral e também a confiança na organização, afetando negativamente o desempenho futuro;

- bullying, é quando a pressão, no sentido do alcance das metas, acaba provocando situações assédio e intimidação.

Não foram encontrados estudos que investigaram, especificamente, no contexto das OS estaduais e municipais de São Paulo, a ocorrência de tais distorções. Ainda assim, denúncias de profissionais e usuários nos levam a formular a hipótese de que tais distorções acometem de forma importante o desempenho dos serviços de saúde administrados por OS.

Talvez a denúncia mais grave relacionada a esse tipo de distorção se refere à seleção adversa de pacientes de maior rentabilidade, por parte de hospitais gerenciados pelas OS, prática também chamada de "cream skimming"101 (RELMAN, 1980). Diferente de hospitais privados, que escolheriam aqueles pacientes capazes de proporcionar o maior lucro, os serviços gerenciados por OS selecionariam aqueles pacientes que lhe proporcionassem um melhor desempenho nas metas de

101 Essa expressão é utilizada na literatura no campo da saúde privada, quando se refere a uma escolha de pacientes por alguma característica que não seja a sua necessidade de cuidados, propiciando o aumento da rentabilidade do fornecedor. 
produtividade e qualidade, como menor mortalidade, menor tempo de internação, menores custos.

A reportagem "Hospital dispensava idosos e internava jovens para bater meta", veiculada pelo Jornal da Band (2014), em 5 de dezembro de 2014, expunha esquema realizado em importante hospital da capital paulista por uma equipe de médicos terceirizados ${ }^{102}$. Os médicos eram orientados acerca de quantos pacientes poderiam internar e também que tipo de paciente deveria ser internado:

"COLEGAS- 'INTERNAÇÕES BREVES'. Esses pacientes devem ser JOVENS, Hígidos, com diagnósticos simples e precisos, para podermos dar alta com segurança! EVITEM Pacientes Idosos, com ICC [Insuficiência Cardíaca Congestiva], Pneumonia e Múltiplas Comorbidades" (JORNAL DA BAND, 2014).

Segundo a reportagem, alguns pacientes dispensados pelo hospital acabavam sendo atendidos em outros hospitais da rede municipal. Se utilizadas as categorias descritas por Mannion e Braithwaite (2012) e Goddard et al (1998), somente nesse caso já poderíamos destacar a ocorrência:

- o foco excessivo no alcance das metas estipuladas, mesmo que isso signifique distorcer o sentido pelo qual o marcador foi formulado (measurement fixation), exemplificado aqui pela seleção adversa de pacientes, buscando menores tempos de internação;

- uma dificuldade desse hospital em realizar sua tarefa na rede de saúde, sobrecarregando outros serviços (fragmentation), exemplificado pelos pacientes mais graves que precisaram buscar outros hospitais.

O estudo de Ballarotti (2015) também identifica algumas distorções na atuação dos serviços geridos pelas OS, mas dessa vez na APS municipal, objeto de nosso estudo. A seguir destacaremos alguns trechos das entrevistas realizadas pela autora e realizaremos breve discussão com base nas categorias descritas por Mannion e Braithwaite (2012) e Goddard et al (1998).

102 O hospital filantrópico é um dos hospitais geridos pelas OS, e presta serviços ao SUS mediante Contrato de Gestão com o governo estadual. Pertence também a uma das principais "parceiras" na implementação do PSF na cidade de São Paulo. Segundo a reportagem, o hospital teria assumido que deve cumprir metas, junto à Secretaria Estadual de Saúde, no entanto negou responsabilidade pelo ocorrido, reputando o esquema denunciado a médicos terceirizados que atuavam no prontosocorro do hospital. 
Sobre a gestão da unidade, uma das médicas entrevistadas relata:

"Agora é contrato de gestão que eles falam. Mudou o contrato de gestão da OS com a prefeitura. Então que sei que agora tudo fica muito baseado em números. [...] Foi dito em tom de ameaça. Para médico ninguém falou nada, até porque estamos sem um médico lá, então também não tem nem como não bater meta. [...] A reunião que estava a supervisora. Um fala que isso vem da prefeitura, a prefeitura diz que vem da OS Amarela. A OS Amarela tem que cumprir o que a prefeitura está exigindo senão ela perde o contrato dela. Como ela tem que cobrar da gerente, ela tem que cobrar de nós para todo mundo ficar empregado, foi meio ameaça. Só que eu estou me lixando" (BALLAROTTI, 2015, p. 52-3).

Em outro trecho a mesma médica discute tema semelhante:

"Então, eu acho que isso pra mim é assédio moral, coação e algo mais. Eu falo para meninas, as ACS da minha equipe, 'vocês conhecem todas as metas? Vocês trabalham direitinho, não fiquem preocupadas com isso. Vocês sempre cumpriram, vocês não precisam trabalhar nervosas, vocês vão ficar doentes e ai sim vai ser pior'. Mas falar isso, eu acho que é uma coisa ruim. Faltando tanto profissional, faltando tanta gente boa." (BALLAROTTI, 2015, p. 61).

É importante aqui destacar também um terceiro trecho:

"Então a gente tem que cumprir por [exemplo a] questão do número de consultas, do tempo por hora, não tem como. Com esses cursos [reuniões clínicas] acho que vai ficar cada vez mais limitado. [...] porque eles falam que os médicos não querem vir, mas eu tenho certeza que eles querem vir. Tenho certeza que é por causa dessa bendita produção que eles não querem mandar os médicos [para reuniões clínicas]. [...] Então assim, às vezes quando a gente ouve a supervisora da OS Amarela falando assim: 'então tem que pensar que se não atingirmos a meta... por que uma [pessoa] atinge e a outra não? Por que será? De repente a gente pode trocar esse profissional'. [...] De forma que os profissionais ficam doentes [...] o estresse, agrava tudo" (BALLAROTTI, 2015, p. 67).

Nos excertos destacados é possível identificar algumas das distorções listadas anteriormente. O trecho "agora tudo fica muito baseado em números" é um indício de uma atenção exacerbada a aspectos quantitativos (quantification privileging).

A partir dos fragmentos: no primeiro excerto: "ela tem que cobrar de nós para todo mundo ficar empregado, foi meio ameaça"; no segundo excerto, em que a médica diz "isso pra mim é assédio moral"; e do terceiro excerto se identificam indícios de cobranças exacerbadas, que acabam por propiciar situações de intimidação e assédio (bullying). 
O trecho "só que eu estou me lixando" do primeiro excerto e a última parte do terceiro excerto, "os profissionais ficam doentes [...] o estresse agrava tudo", trazem indícios de que as cobranças não são encaradas como justas, e podem prejudicar a confiança dos trabalhadores na organização, além de adoecê-los, desestimulando um melhor desempenho (reduced staff morale).

Em seguida um trecho de outra médica que trabalhava para a mesma OS:

"A administração lá era da OS. A gerente da unidade era indicada pela OS e todo o modo funcionar, todo processo de trabalho, a organização da unidade era determinada pela OS. [...] A agenda era determinada pela OS. [...] A forma de organização do acolhimento também era determinada pela OS. [...] Os horários de reunião de equipe eram determinados pela OS, era obrigado a fazer reunião de equipe todo dia, não podia fazer reunião de equipe de mais tempo durante a semana. Tentamos mudar isso, mas a resposta da gerente é que aquilo não podia, porque a OS Amarela escolhia que ia ser assim" (BALLAROTTI, 2015, p. 60)

Em outro trecho da mesma entrevista, a médica complementa:

E ainda assim a maior parte das coisas eram cortadas com esse argumento: 'Não, a regra é essa, o contrato é esse, o contrato entre a OS e a Prefeitura, entre a OS e vocês. A regra da empresa é essa'" (BALLAROTTI, 2015, p. 75)

Os excertos acima permitem observar evidências de que as metas determinadas no Contrato de Gestão podem estar causando, em alguns casos, uma rigidez excessiva da organização e do processo de trabalho, dificultando com que as equipes busquem melhores soluções para os problemas encontrados no dia a dia (ossification).

Outro trecho da entrevista dessa mesma médica traz evidências de que as metas estipuladas podem estar gerando uma busca exacerbada por aspectos quantitativos (quantification privileging), fazendo com que qualquer interação com o paciente seja considerado "consulta", numa espécie de "contabilidade criativa" (misrepresentation):

"O paciente para ter o problema resolvido ela vai 4 ou 5 vezes na unidade porque ele vai entrar na produção das pessoas 4 ou 5 vezes. Assim você bate a meta. Com o mesmo problema, não fazendo coisas e deixando para o dia seguinte. Por exemplo: você vem hoje porque sua receita vai vencer. Hoje eu te ouvi que sua receita vai vencer, eu fico com sua receita e peço pra você voltar dali a alguns dias. Eu coloco na produção que te ouvi. Daí no dia seguinte, na reunião de equipe, faço sua receita e você entra na produção de novo, pois fiz sua receita. Em um terceiro dia, quando você vier buscar sua receita, você entra na produção de novo. As pessoas 
fazem isso propositalmente e é estimulado pela gerente da unidade" (BALLAROTTI, 2015, p. 67).

Um trecho da entrevista de um outro médico, trabalhador de outra OS, descreve situações semelhantes:

"Na OS Azul a meta era bastante cobrada, tanto de VD [visita domiciliar] quanto de consulta. [...] Então, consulta era sempre fácil de bater meta. VD não. O que a gente fazia? Você tem 4 semanas, você fazia na primeira semana, você via suas prioridades, nas suas outras três semanas, se você precisava voltar em alguém você voltava, senão, você simulava demanda entregava exame normal, ia fazer cadastro com ACS - para bater meta de VD."

O conjunto dos excertos permite formular as hipóteses de que: o foco exacerbado em cumprir as tarefas definidas pelas metas pode estar causando 0 negligenciamento de outras questões também relevantes (tunnel vision); e de que podem acarretar prejuízos a longo prazo (myopia).

O trabalho de Ballarotti (2015) traz diversos outros exemplos das distorções descritas anteriormente; para a discussão realizada nessa seção, destacamos somente alguns trechos.

Reconhecemos que tanto a reportagem citada como o estudo de Ballarotti (2015) não permitem determinar em que dimensão tais problemas afetam o trabalho realizado pelas OS. Não é possível determinar se, em um extremo, são casos isolados, que não representam o trabalho realizado pelas OS, ou se, no outro extremo, afetam de forma sistemática toda a rede de serviços. Ainda assim, com base nas situações e relatos destacados, é possível concluir que: a simples comparação dos indicadores determinados pelos contratos de gestão não é suficiente para determinar se o trabalho realizado por um serviço de saúde é realmente superior àquele realizado por outro.

Tanto o trabalho de Goddard et al (1998) como o de Mannion e Braithwaite (2012) apontam que, para tentar evitar e corrigir tais distorções, é necessária a contínua e exaustiva revisão das metas estabelecidas, assim como também a ativa participação de trabalhadores e usuários na determinação desses indicadores. Discutiremos a seguir alguns aspectos relativos a essa participação no âmbito dos serviços públicos de saúde gerenciados pelas OS. 


\title{
3.2.2 A gestão dos serviços públicos: publicização ou privatização?
}

Como discutido anteriormente, a reforma do estado defendida pelas políticas neoliberais vem frequentemente acompanhadas de uma retórica de fortalecimento da democracia, publicização do Estado, melhor observância dos princípios republicanos. Aqui é importante apontar alguns exemplos.

\section{Retomaremos novamente o Plano Diretor da Reforma do Aparelho do Estado} (1995). Nesse documento, o autor faz a questão de definir a privatização da gestão dos serviços públicos como, na verdade, uma publicização:

\begin{abstract}
"A reforma do Estado deve ser entendida dentro do contexto da redefinição do papel do Estado, que deixa de ser o responsável direto pelo desenvolvimento econômico e social pela via da produção de bens e serviços, para fortalecer-se na função de promotor e regulador desse desenvolvimento. No plano econômico o Estado é essencialmente um instrumento de transferências de renda, que se torna necessário dada a existência de bens públicos e de economias externas, que limitam a capacidade de alocação de recursos do mercado. Para realizar essa função redistribuidora ou realocadora o Estado coleta impostos e os destina aos objetivos clássicos de garantia da ordem interna e da segurança externa, aos objetivos sociais de maior justiça ou igualdade, e aos objetivos econômicos de estabilização e desenvolvimento. Para realizar esses dois últimos objetivos, que se tornaram centrais neste século, o Estado tendeu a assumir funções diretas de execução. As distorções e ineficiências que daí resultaram deixaram claro, entretanto, que reformar o Estado significa transferir para o setor privado as atividades que podem ser controladas pelo mercado. Daí a generalização dos processos de privatização de empresas estatais. Neste plano, entretanto, salientaremos um outro processo tão importante quanto, e que no entretanto não está tão claro: a descentralização para o setor público nãoestatal da execução de serviços que não envolvem o exercício do poder de Estado, mas devem ser subsidiados pelo Estado, como é o caso dos serviços de educação, saúde, cultura e pesquisa científica. Chamaremos a esse processo de 'publicização'. [...] Finalmente, através de um programa de publicização, transfere-se para o setor público não-estatal a produção dos serviços competitivos ou não-exclusivos do Estado, estabelecendo-se um sistema de parceria entre Estado e sociedade para seu financiamento e controle" (BRASIL, 1995, p. 12-3).
\end{abstract}

Para essa "publicização", portanto, a execução de certos serviços "nãoexclusivos" deveria deixar de ser realizada pelo próprio Estado, e ser assumido por um setor "público não-estatal", por meio da criação de Organizações Sociais:

"Transferir para o setor publico não-estatal estes serviços, através de um programa de 'publicização', transformando as atuais fundações públicas em organizações sociais, ou seja, em entidades de direito privado, sem fins lucrativos, que tenham autorização específica do poder legislativo para 
celebrar contrato de gestão com o poder executivo e assim ter direito a dotação orçamentária" (BRASIL, 1995, p. 46).

A posição adotada pelo governo federal naquele momento foi objeto de duras críticas por parte dos setores de esquerda e também por parte daqueles setores historicamente associados ao trabalho organizado. A lei federal $n=9.637 / 1998$, que regulamenta a atuação das OS, foi alvo de uma Ação Direta de Inconstitucionalidade (ADIn) protocolada em 1998 pelo Partido dos Trabalhadores (PT) e pelo Partido Democrático Trabalhista (PDT). Eram criticadas: a tentativa de delegar ao setor privado o protagonismo na execução dos serviços públicos, não limitando a atuação desse setor ao caráter complementar que Ihe seria permitido pela Constituição; e a falta da observância aos princípios da transparência e impessoalidade na contratação, pelo Poder Executivo, de tais entidades ${ }^{103}$.

Como vimos na seção 3.1.2, a contratação de Organizações Sociais pela Prefeitura Municipal de São Paulo só foi regulamentada no ano de 2006, com o primeiro Contrato de Gestão desse tipo para prover serviços de saúde sendo realizado somente em 2007. Apesar disso, desde muito antes, o governo municipal vinha contratando entidades privadas para gerir serviços públicos de saúde, sendo o PAS (1996-2000), de Maluf e Pitta, o primeiro exemplo.

O PAS foi duramente criticado, tanto por setores ligados ao PSDB (os próprios governos federal e estadual de então), como por aqueles setores ligados ao PT - os dois partidos que dicotomizariam a política nacional nos anos seguintes. Apesar disso, os governos de ambos partidos adotaram táticas semelhantes na organização dos serviços de saúde na cidade de São Paulo.

Em 1996, ainda antes da aprovação das leis federal e estadual que regulamentam as OS, o governo estadual do PSDB criou o Qualis. Foi a partir do convênio com uma entidade privada que se iniciou, na cidade de São Paulo, a implementação do PSF. A partir de 2001, ao assumir a prefeitura, o governo municipal do $\mathrm{PT}^{104}$ assumiria também as unidades estaduais do Qualis. O governo municipal manteve os convênios e ainda os ampliou: de quatro, passaram a ser doze as entidades conveniadas (SOUSA, 2003). A principal prioridade daquele

103 Ver Frente Nacional contra a Privatização da Saúde (2012) e Marques e Mendes (2015).

104 Governo que, segundo seus próprios integrantes, deveria trazer "São Paulo de volta ao Brasil e à Constituição" (SOBRINHO, 2003b). 
governo na área da saúde passaria a ser implementada por meio de convênios (SOBRINHO, 2003a); um modelo de gestão que, como vimos na seção 3.1.2, apresenta transparência e controle público ainda mais débeis do que o modelo das OS - modelo que o partido havia contestado apenas 3 anos antes em uma ADIn ${ }^{105}$.

Frente à flagrante contradição, resgata-se o argumento da "publicização". Assim como Sousa (2003), em trecho citado na seção 3.1.2, Inojosa (2003) descreve as parcerias como o fortalecimento da participação da comunidade no planejamento e execução das políticas públicas, na criação de uma "rede de compromisso social":

"A oportunidade que o modelo de rede representa é a possibilidade de
reunir, em torno de um objetivo comum, entes com objetivos próprios e
articular serviços que antes eram isolados e setorializados. Outra
vantagem é permitir o planejamento e a avaliação de resultados e
impactos, isto é, buscando conferir o que está mudando para melhor na
vida da população ou que escolhas devem ser feitas no sentido da
equanimidade. [...] Trata-se de reforçar a participação do cidadão, não
apenas na dimensão do exercício do poder de reivindicar, 'mas o poder de
controlar, e mais além do poder de controlar, o poder de gerir recursos'. E
isso, no sentido de vincular as representações dos cidadãos e as
organizações privadas lucrativas e não lucrativas aos destinos de seu
ambiente imediato, porque há estreita relação entre a construção e o
fortalecimento da identidade cultural e desenvolvimento social" (INOJOSA,
2003, p. 105-6).

Ambas as autoras apresentam, portanto, o estabelecimento de parcerias para gerir os serviços públicos de saúde como uma ação que busca maior democratização e publicização do Estado.

Mas por que maneira se daria essa maior participação da comunidade? Seria o caráter "filantrópico", ou a relação das "instituições parceiras" com atividades de ensino, suficientes para garantir tal participação?

$105 \mathrm{Na}$ ocasião do falecimento de Margaret Thatcher, Zizek (2013) escreveu breve texto analisando o seu legado. Dali se extrai o seguinte trecho: "Quando perguntaram a Margaret Thatcher sobre seu maior êxito, ela respondeu sem pestanejar: 'O New Labour'. E ela estava certa: seu triunfo foi o fato de suas políticas econômicas básicas terem sido adotadas até mesmo por seus inimigos econômicos - o verdadeiro triunfo não é a vitória sobre o inimigo, ele ocorre quando o próprio inimigo começa a usar sua linguagem, de modo que suas ideias formem a base de todo o campo" (ZIZEK, 2013). Talvez aqui, guardadas as devidas proporções, possamos dizer que a maior vitória das políticas neoliberais da década de 1990 foi justamente a política de governos "populares" dos anos 2000. 
Para Nassuno (1999), além do controle da OS realizado pelo próprio Poder Executivo, que se dá por meio do Contrato de Gestão ${ }^{106}$, os próprios usuários do serviço devem ter a capacidade de influenciar a maneira pela qual esses serviços são prestados, através dos mecanismos de "voice" e "exif". Para a autora, somente a participação dos usuários poderia garantir a qualidade e a eficiência dos serviços ${ }^{107}$. O mecanismo de "voice" seria semelhante ao que chamamos de Controle Social e, aplicado ao caso das OS, seria materializado através da participação dos usuários no conselho de administração das $\operatorname{OS}^{108}$ :

"o instrumento de controle social previsto no projeto das organizações sociais refere-se à participação de entidades representativas da sociedade civil no conselho de administração" (NASSUNO, 1999, p. 338).

O mecanismo de "exit" seria materializado através da possibilidade dos usuários escolherem entre diferentes prestadores de serviço.

Como discutimos anteriormente, nem mesmo no PAS foi aplicado o mecanismo de competição entre as prestadoras de serviços. No caso das OS e OS símiles, não há possibilidade, por parte do usuário, de escolher entre diferentes prestadoras; no caso específico da APS, por exemplo, a unidade a ser utilizada normalmente é determinada pelo endereço do usuário. Não há, portanto, no caso estudado, o mecanismo de "exit".

Restaria como forma de participação do usuário, o mecanismo de "voice", que segundo a autora seria concretizado pela participação dos usuários nos conselhos de administração das OS.

\footnotetext{
106 O Contrato de Gestão seria o meio pelo qual o Executivo determina as "atribuições, responsabilidades e obrigações da OS no desempenho de ações e serviços a seu cargo" (NASSUNO, 1999, p. 338), e sua avaliação seria realizada através da análise das metas estipuladas. 107 Sobre a importância da participação dos usuários escreve a autora: "É necessário analisar a possibilidade de organização dos usuários, pois, se ela não se concretizar, as informações sobre desempenho dos burocratas poderão ser fornecidas por outros grupos organizados, como o dos fornecedores da instituição e dos próprios burocratas. No entanto, só entidades que representem os interesses dos usuários resolvem o problema da ineficiência decorrente da relação principal-agente entre políticos e burocratas mencionado anteriormente" (NASSUNO, 1999, p. 345-6). Em outro trecho escreve: "Os burocratas que dirigem as OS devem prestar contas dos atos de sua gestão a representantes de seus clientes com assento no conselho de administração" (NASSUNO, 1999, p. 353)

108 O mesmo é previsto no PDRAE: "A propriedade pública não-estatal torna mais fácil e direto o controle social, através da participação nos conselhos de administração dos diversos segmentos envolvidos, ao mesmo tempo que favorece a parceria entre sociedade e Estado" (BRASIL, 1995, p. 43).
} 
No caso do município de São Paulo, a constituição do Conselho de Administração é definida pela Lei municipal no 14.132/2006, que regulamenta as OS. No que se refere ao Conselho de Administração, para ser qualificada como OS pelo Poder Executivo, a entidade deve compô-lo da seguinte maneira:

“a) $55 \%$ (cinqüenta e cinco por cento), no caso de associação civil, de membros eleitos dentre os membros ou os associados; [...] b) $35 \%$ (trinta e cinco por cento) de membros eleitos pelos demais integrantes do Conselho, dentre pessoas de notória capacidade profissional e reconhecida idoneidade moral; [...] c) $10 \%$ (dez por cento) de membros eleitos pelos empregados da entidade" (SÃO PAULO (CIDADE), 2006)

A lei municipal também previa a formação de uma "Comissão de Avaliação", composta por dois "membros da sociedade civil, escolhidos dentre os membros do Conselho Municipal de Saúde ou dos Conselhos Gestores dos equipamentos incluídos nos Contratos de Gestão"; um membro indicado pela Câmara Municipal de São Paulo; e três membros do Executivo "com notória capacidade e adequada qualificação". A função dessa comissão seria acompanhar e fiscalizar a execução dos contratos de gestão celebrados por organizações sociais "no âmbito de sua competência" (SÃO PAULO (CIDADE), 2006).

A lei municipal no 14.664/2008 muda, no entanto, a composição da Comissão de Avaliação: mantém-se os dois membros "da sociedade civil", mas passam a ser dois os representantes indicados pela Câmara Municipal e quatro os representantes do executivo. Muda também o seu papel, que passa a ser somente o de avaliar o Contrato de Gestão antes de sua assinatura.

A mesma lei cria também a Comissão de Acompanhamento e Fiscalização (CAF), que passaria, a partir de então, a acompanhar e fiscalizar a "execução do contrato de gestão firmado com a organização social no âmbito de sua competência". A CAF deve ser composta por três membros do Poder Executivo e dois "membros da sociedade civil", mas diferente da Comissão de Avaliação, não há detalhes sobre como esses membros da sociedade civil deveriam ser escolhidos.

Pela análise dessas leis, seria possível dizer que não há realmente a garantia da participação dos próprios usuários dos serviços que estão sendo objeto do Contrato de Gestão. A composição do Conselho de Administração da OS, apontado como Nassuno (1999) como principal instância de controle social, não garante a sua 
participação, e o mesmo acontece com as instâncias previstas pelas leis municipais, a Comissão de Avaliação e a CAF ${ }^{109}$.

Contreiras e Matta (2015) discutem os mecanismos de controle das OS e dos convênios com entidades "OS símiles". Como discutido na seção 3.1.2, o controle sobre as entidades conveniadas é ainda mais débil do que aquele realizado sobre as OS. Sobre o desempenho dos mecanismos de controle sobre as OS, os autores descrevem ${ }^{110}$ :

"Foram identificadas diversas irregularidades: a prefeitura não respeitou a lei que exigia a constituição das $\mathrm{CAF}$, instituindo a primeira somente no fim de 2010; não cumprimento das obrigações por parte da CAF; não cumprimento de metas; não execução de todo o dinheiro repassado; escassez de funcionários no NTCSS e falta de informatização; aprovação pelo NTCSS de prestações de contas com erros; falhas na elaboração de indicadores de desempenho; desrespeito aos regulamentos de compras; atrasos nos repasses dos recursos por parte da SMS. As reiteradas recomendações do TCM, em muito ignoradas pela SMS, levaram a Câmara Municipal a instaurar a Subcomissão das OS, comissão de investigação com o objetivo de avaliar a efetividade regulatória do Executivo e cujos trabalhos foram conduzidos de junho a setembro de 2011. Entre as conclusões da Subcomissão estavam: o despreparo da SMS em controlar os vultuosos contratos; o fato de que continuava havendo somente uma CAF em vez de uma para cada contrato de gestão; a existência de contratos que não haviam sido avaliados pela Comissão de Avaliação; e a omissão da Auditoria Geral, que nunca havia auditado nenhum dos contratos de gestão. [...] Sobre a possibilidade de fiscalização pela sociedade, alguns aspectos se destacam: foi prejudicada pelo atraso na constituição da CAF; a disponibilização dos contratos de gestão na internet constitui um avanço em transparência; as audiências públicas de prestações de contas da SMS conferiram especial atenção às OS, [...]. Ressalte-se, contudo, que foram apresentados somente dados sobre orçamento e cobertura dos serviços, tendo sido excluídos os indicadores de resultados, cumprimento de metas ou gestão financeira" (CONTREIRAS; MATTA, 2015, p. 293-4).

Em relação aos controles que incidem sobre as entidades conveniadas, que os autores denominam "OS símiles" argumentam que:

\footnotetext{
109 Nassuno (1999) diferencia a participação de "entidades da sociedade civil" no sentido amplo, da participação de representantes dos usuários: "Na discussão aqui proposta faz-se distinção entre entidades representativas da sociedade civil e entidades representativas de interesses dos usuários. Embora estas últimas possam constituir-se também em entidades representativas da sociedade civil, a recíproca não é verdadeira. [...] só entidades que representem os interesses dos usuários resolvem o problema da ineficiência" (NASSUNO, 1999, p. 345).

110 O Núcleo Técnico de Contratação de Serviços de Saúde (NTCSS) foi instituído pela SMS para atuar no monitoramento e avaliação dos serviços prestados pelas parceiras, e está previsto nos Contratos de Gestão da PMSP com as OS (SECRETARIA MUNICIPAL DE SAÚDE DE SÃO PAULO, 2015b). O Tribunal de Contas do Município (TCM) é órgão pertencente à estrutura da esfera municipal e que tem como papel "a fiscalização e o controle da Receita e da Despesa do Município de São Paulo" (TRIBUNAL DE CONTAS DO MUNICÍPIO DE SÃO PAULO, 2016).
} 
O aparato regulatório direcionado às entidades conveniadas OS símiles está descrito em um documento chamado "Instrumento Normativo", lançado pela SMS em 2008. Baseia-se em controle contábil e de resultados, aferidos com base em indicadores de gestão de material, de recursos humanos, epidemiológicos e operacionais. Para a análise dos indicadores, foram criadas Comissões de Acompanhamento formadas por gestores da SMS e submetidas à Coordenadoria de Atenção Básica. Os convênios não são fiscalizados pelo NTCSS. [...] Em relação ao controle externo, verificou-se que o TCM abordou os convênios nos relatórios de 2007 e 2008, criticando a debilidade da fiscalização e a subutilização de recursos repassados. O tópico, porém, está ausente nos relatórios entre 2009 e 2011. O relatório da Subcomissão das OS da Câmara também ignorou os convênios. Vale destacar que, à época, provavelmente ainda não fora publicado o relatório do TCM em que as despesas com OS símiles ganharam visibilidade em razão da reorganização da descrição orçamentária. [...] O papel fiscalizador da sociedade civil é limitado nos convênios: não está prevista a sua participação nas Comissões de Acompanhamento; os ajustes não estão disponíveis na internet nem foram fornecidos quando solicitados para esta pesquisa; e, nas prestações de contas da SMS, aos convênios é destinada somente uma página a cada ano, limitando-se a informação ao total repassado por entidade (CONTREIRAS; MATTA, 2015, p. 294).

Além do Conselho de Administração da OS, da Comissão de Avaliação que ficou com incumbência de avaliar o Contrato de Gestão antes de sua assinatura e da CAF, que ficou responsável por fiscalizar a execução do contrato, os autores também apontam, enquanto instrumento de controle, o Núcleo Técnico de Contratação de Serviços de Saúde (NTCSS), que é um órgão técnico da própria SMS, e que não prevê também a participação de usuários. Pelo analisado, portanto, a implementação das OS em São Paulo não garantiu institucionalmente nenhum instrumento permanente de controle social que garanta a participação dos usuários. $\mathrm{O}$ único colegiado permanente de controle e avaliação, a CAF, que prevê a participação de "dois membro da sociedade civil" (SÃO PAULO (CIDADE), 2008), não especifica se esses "membros" representariam ou não os usuários e nem especifica como eles seriam escolhidos. Como apontam Contreiras e Matta (2015) no trecho destacado anteriormente, mesmo esse colegiado teve funcionamento irregular e insuficiente.

O Contrato de Gestão proposto pela SMS no chamamento de 2015, para a região do Butantã (SECRETARIA MUNICIPAL DE SAÚDE DE SÃO PAULO, 2015b) também apresenta alguns itens referentes ao controle social. $O$ contrato institui alguns "indicadores de qualidade", e o descumprimento do conjunto desses 
indicadores pode acarretar um desconto de até $5 \%$ no valor repassado. Dentre esses indicadores, dois estão relacionados à participação do usuário.

Um deles é descrito como um indicador de "Satisfação do Usuário" e envolve a entrega, por parte da OS, de relatório comentado acerca de todas as reclamações recebidas através da ouvidoria do SUS, bem como das providências adotadas. $O$ outro é um indicador do funcionamento do Conselho Gestor das unidades, no qual a OS deve apresentar a ata das reuniões dos Conselhos Gestores, como prova da realização de ao menos $80 \%$ das reuniões previstas.

Muito embora sejam duas providências que valorizam a opinião e a participação do usuário, não fica claro, através da análise desses documentos, qual seria efetivamente o papel que a opinião do usuário acabaria por cumprir, por meio desses dois instrumentos, na determinação do funcionamento das unidades. Mais estudos são necessários para esclarecer esse ponto. É importante destacar, no entanto, que tanto o Conselho Gestor das unidades como a Ouvidoria do SUS são instrumentos de participação do próprio SUS, não são instrumentos específicos da gestão pelas OS, e também estão presentes em unidades geridas diretamente pelo Estado.

Por meio do analisado, não há evidências que justifiquem a afirmação de que a cessão da gestão dos serviços de saúde públicos para as OS, em São Paulo, foi responsável por um aumento da participação da comunidade no planejamento ou na execução dos serviços de saúde.

O estudo de Ballarotti (2015) permite, no entanto, estabelecer algumas hipóteses acerca da participação dos trabalhadores na organização desses serviços. Destacaremos a seguir trechos de algumas das entrevistas.

Um dos médicos entrevistados refere bastante autonomia para organizar os processos de trabalho de sua equipe, mas refere pouca abertura para discutir processos determinados pela prefeitura ou pela OS:

"Acho que a diferença é quando a gente sai do micro e tem que discutir dentro da prefeitura ou dentro da OS. Meio que a gente não tem voz em lugar nenhum. Difícil de discutir com a supervisão, como eu citei a questão do email que ninguém responde. Não tem uma questão vamos conversar, vamos montar alguma coisa. A sensação é que fico isolado na unidade mesmo, não sei se isso é por existir duas pessoas fazendo a gestão do 
mesmo lugar (OS e prefeitura), fico um pouco na dúvida" (BALLAROTTI, 2015, p. 74)

Duas médicas trabalhadoras de outra OS também descreveram pouca margem para discutir as determinações da OS. A primeira descreve da seguinte forma:

"[sobre participação dos trabalhadores na gestão da unidade] "Não. Fora do espaço da reunião, não. Tinha esse espaço da reunião desde que não mexesse no que está pré-determinado pela OS. O que vem da OS, a resposta que vinha é que era assim e tem que ser assim e pronto." [...] "Não tinha muita tentativa. Não, era bem fechado, não era estimulado. Não via essa demanda por parte dos trabalhadores. E quando existia era por questões pontuais, era mais por incômodo do processo de trabalho individual e não do cuidado do paciente. E ainda assim a maior parte das coisas eram cortadas com esse argumento: 'Não, a regra é essa, o contrato é esse, o contrato entre a OS e a Prefeitura, entre a OS e vocês. A regra da empresa é essa'" (BALLAROTTI, 2015, p. 75).

A segunda médica apresenta avaliação semelhante:

"Eu acho que a gente não tem poder de decisão. Nós que estamos aqui embaixo, a gente não tem poder de decisão. A gente tem espaço pra expor as nossas ideias. Nas reuniões vão as pessoas da prefeitura, da OS Amarela, tem a Maria que é apoiadora, ela escuta o que a gente fala, mas no frigir dos ovos, é uma coisa que eles falam que tem que ser assim e vai ser assim. Isso não mudou nada nesses 14 anos" (BALLAROTTI, 2015, p. 75)

Um quarto médico entrevistado, que havia trabalhado para uma terceira OS, também compartilhava a avaliação de que, muitas vezes, as decisões eram implementadas de forma vertical, apesar de realizar uma avaliação positiva do processo:

"Então, apesar de ser vertical, de cima para baixo, do jeito que tinha que
ser, [...] no trabalho a gente começou a sentir melhor, no agendamento, na
agenda eletrônica, na questão da supervisão, as discussões que tinham...
reunião de responsáveis técnicos das unidades. [...] Pouco espaço, porque
dentro da unidade até tem. Se for coisa para gente resolver dentro da
unidade, alguma gerente tem um olhar diferenciado. Mas se for uma coisa
que não depende de mim... uma ordem. Por exemplo: 'tem que seguir
esse documento aqui'. Não vou mudar. O que deveria ter é uma
rediscussão sempre. Até no nível da gestão, da OS, da instituição, da
secretaria. (...)" (BALLAROTTI, 2015, p. 75).

Ao analisar o conjunto das entrevistas, a autora conclui o seguinte acerca desse tema:

Apesar dos relatos anteriores de uma estrutura verticalizada, todos médicos relataram a existência de espaços formais de discussão de 
processo de trabalho nas suas unidades de saúde. Porém, quando se trata de poder deliberativo desses espaços, ou mesmo de discussão qualificada, todos fizeram críticas. As críticas envolvem desde o fato de haver uma hierarquia de poder dentro da UBS, sendo os ACS os que tem menor possibilidade de serem ouvidos; até relatos de que, na prática, mesmo os médicos não têm voz dentro da estrutura da organização; relatos de limitações das possibilidades de arranjos em função das "regras da empresa"; relatos de intimidação dos trabalhadores nas discussões pela presença da gestão; percepção de que as reuniões existem apenas para cumprir a regra, entre outros.

Tanto os relatos destacados, como a própria análise da autora, dão conta da existência de espaços para discussão, porém com pouca capacidade de deliberação. Muita embora o estudo qualitativo da autora não permita a tomada de conclusões definitivas, permite formular a hipótese de que a participação dos trabalhadores na determinação dos processos de trabalho nas unidades de ESF geridas pelas OS é bastante limitada. Como discutimos na seção anterior, tal situação pode gerar repercussões bastante graves na qualidade dos serviços de saúde.

A gestão privada da produção dos serviços públicos de saúde, na maneira como ela foi realizada até hoje na cidade de São Paulo, não parece integrar, portanto, um processo de "publicização", no qual se observa ou se representa de forma mais adequada os interesses públicos. Pelo contrário, a expressão concreta desses serviços parece representar melhor os interesses particulares das classes proprietárias, principalmente daquelas frações que dependem, para realizar a valorização de seu capital, do orçamento do Estado.

Dentre essas frações, como discutimos no Capitulo 1, parece ter grande importância os interesses da finança. A seção a seguir discutirá a terceirização dos serviços de saúde em São Paulo à luz dessa proeminência e da "insaciabilidade" do capital portador de juros.

\subsection{A terceirização dos serviços públicos em São Paulo e o capital portador de juros}

A ofensiva das classes proprietárias que dá origem ao neoliberalismo acompanha também uma importante mudança no paradigma de organização do trabalho. Do paradigma taylorista/fordista, passaria a se observar o fortalecimento dos processos de "acumulação flexível" (ANTUNES; DRUCK, 2013). 
Como apontam Antunes e Druck (2013), o avanço da terceirização e das novas maneiras de organização do trabalho estão intrinsecamente ligadas ao avanço do capital portador de juros:

No quadro mais geral da dinâmica da acumulação flexível, a precarização social contemporânea do trabalho se torna o centro das transformações produtivas do capitalismo em suas várias dimensões. Nesta última década no Brasil, o crescimento e a difusão da terceirização a reafirma como uma modalidade de gestão, organização e controle do trabalho num ambiente comandado pela lógica da acumulação financeira, que, no âmbito do processo de trabalho, das condições de trabalho e do mercado de trabalho, exige total flexibilidade em todos os níveis, instituindo um novo tipo de precarização que passa a dirigir a relação capital-trabalho em todas as suas dimensões. E, num quadro em que a economia está comandada pela lógica financeira sustentada no curtíssimo prazo, as empresas do setor industrial buscam garantir seus altos lucros, exigindo e transferindo aos trabalhadores a pressão pela maximização do tempo, pelas altas taxas de produtividade, pela redução dos custos com o trabalho e pela "volatilidade" nas formas de inserção e de contratos. É o que sintetiza a terceirização, que, como nenhuma outra modalidade de gestão, garante e efetiva essa "urgência produtiva" determinada pelo processo de financeirização ao qual estão subordinados todos os setores de atividade, já que são também agentes e sócios acionistas do capital financeiro (ANTUNES; DRUCK, 2013, p. 219).

Chesnais (2005) discute esses processos nos termos da "exterioridade da finança em relação à produção"111. Como discutido na seção 1.2.1, uma das principais repercussões do processo de liberalização financeira e reativação das bolsas de valores a partir da década de 1980, é que a finança conseguiu alojar no cerne dos grupos industriais o tipo de exigência de rentabilidade típica do capital portador de juros (CHESNAIS, 2005, p. 53-4). Chesnais (2010) descreve esse processo:

Face ao objetivo de maximização do valor acionário para responder às exigências dos mercados e à intensificação da concorrência, os dirigentes de empresas privilegiaram as medidas que encontram as "preferências" da coletividade de investidores: redução dos custos por meio de um conjunto de demissões maciças, restruturação de grupos em torno dos segmentos com atividades mais rentáveis, programas recorrentes de recompra de ações e, sobretudo, de downsizing (diminuição de tamanho) e externalização das operações (p.162).

Esse processo de reestruturação envolve a aplicação de táticas para facilitar o controle da finança sobre a produção, como a criação das holdings financeiras. A holding é uma empresa que emprega diretamente somente algumas centenas de

111 Ver Chesnais (2005, p.52-6). 
funcionários, dedicados à máxima valorização financeira, mas que pode apresentar uma vasta rede de filiais, tanto financeiras, como produtivas. São as filiais produtivas que terão de enfrentar a tarefa de organizar a extração de valor por meio da produção. Normalmente transnacionais, essas filiais de produção, também externalizam a produção em direção a empresas menores, com as quais estabelecem contratos de subcontratação e "parcerias", jogando para ainda mais longe de si os loci de extração de mais-valor e os riscos associados à produção. Sobre esse processo escreve Chesnais:

A externalização em grande escala precedeu e preparou a flexibilização e
a precarização. Antes de poder se impor ao fator trabalho por meio de
políticas de flexibilidade e de precariedade, um equivalente da propriedade
líquida que o mercado financeiro dota o capital, era necessário ter acabado
com as grandes unidades de produção. Era necessário que a tarefa de
disciplinar os assalariados fosse transferida a empresas pequenas e
vulneráveis, e portanto ferozes em sua vontade de maximizar a quantidade
de trabalho fornecida por seus assalariados (CHESNAIS, 2010, p.165).

Ou seja, a reestruturação produtiva na qual a terceirização se insere tem relação importante com essa situação na qual, ao mesmo tempo em que a remuneração do capital portador de juros passa a comandar o processo de extração de trabalho excedente das atividades produtivas, há certa "distância da finança em relação às atividades de produção e investimento" (CHESNAIS, 2005, p. 53)

É justamente nesses princípios, que orientaram a reestruturação produtiva discutida, que se inspiram os formuladores das políticas neoliberais para o Estado. Não é de se espantar que, justamente uma instituição financeira, o Banco Mundial, tenha sido uma das principais fomentadoras das reformas desse tipo.

Aqui, o "downsizing" se transforma no "enxugamento" da burocracia do Estado, e a "externalização da produção" se traduz na terceirização dos serviços públicos em favor das OS ou de outras parceiras do mesmo tipo. Como no exemplo das holdings financeiras, para os defensores das políticas neoliberais parece ser necessário manter a estrutura administrativa do Estado bastante reduzida, para que possa estar absolutamente comprometida com a geração de recursos excedentes (ou "superávit primário", na linguagem corrente), que possam ser apropriados pelo capital portador de juros. Enquanto isso, as tarefas de produção de bens e serviços, ainda que orientadas à realização desse excedente, devem ser realizadas por espécies de "filiais" - não na relação vertical que o Estado estabeleceria com seus 
servidores, mas em uma relação "horizontal" do Estado com as prestadoras privadas, uma relação de "parceria".

Nesse caso também parece partir-se do pressuposto de que "a tarefa de disciplinar os assalariados" seria mais bem realizada se "transferida a empresas pequenas e vulneráveis"112, "ferozes" em sua capacidade de extrair trabalho excedente. O trabalho de Ballarotti (2015), que entrevistou médicos da ESF em São Paulo, ilustra a pressão das OS e "OS símiles" sobre os trabalhadores, no sentido de intensificar a extração de mais valor. A seguir, o depoimento de mais um médico:

"O discurso é o seguinte: vamos fazer as metas, se as pessoas começarem a reclamar das metas, de que tem que justificar toda hora, de [que] quantidade não mede qualidade... O gerente dizia 'se vocês não provarem que precisa, que vocês estão cobrindo as metas, se você falar assim: pra baixo, talvez o governo pense que aqui não precisa... Vamos fechar essa unidade, vamos investir em outro, vamos diminuir as equipes, e tal.' Tinha muito terrorismo nessa parte" (BALLAROTTI, 2015, p. 68).

O referido estudo permite levantar questionamentos acerca das diretrizes que regem o processo de trabalho nas unidades geridas pelas instituições parceiras. Como discutido na seção 3.2.1, é possível, a partir dos depoimentos, estabelecer a hipótese de que há uma atenção exagerada para metas quantitativas relacionadas ao número de consultas, enquanto aspectos relacionados à qualidade do cuidado acabam por ser negligenciados. Outro depoimento ilustra essa situação:

"Não existe, tipo supervisão técnica clínica, ativa. Não tem ninguém que vai lá avaliar meu trabalho, pra ver se eu estou fazendo certo ou errado. O cara vai querer saber quantos pacientes eu atendi" (BALLAROTTI, 2015, p. 60)

Se a hipótese se confirmar verdadeira, poderíamos inferir que o "ganho de eficiência", a que se referem os defensores do modelo encontrado no município São Paulo (ORLANDO, 2012), não parece vir de uma melhor incorporação da tecnologia ou da adoção de melhores maneiras de organizar o processo de trabalho, mas apenas da intensificação do trabalho, realizado muitas vezes à custa da saúde do trabalhador. Sobre processo semelhante na Europa escreve Wahl (2011):

112 Como descrevem Contreiras e Matta (2015), as entidades que realizam parceria com a PMSP não são exatamente "pequenas", uma vez que cinco dessas entidades incluem-se entre as dez maiores empresas do país no setor de serviços médicos. Ainda assim, no contexto da atuação dessas empresas na prestação de serviços via convênio ou Contrato de Gestão, as margens parecem ser estreitas, ainda mais se considerado que o não cumprimento das metas pode significar a diminuição dos repasses realizados pela prefeitura (SECRETARIA MUNICIPAL DE SAÚDE DE SÃO PAULO, 2015b). 
"Ganhos de eficiência resultantes do desenvolvimento tecnológico ou de melhores formas de organização - e que não são às custas do ambiente de trabalho, da qualidade ou da intensidade do trabalho - essa é uma meta que vale a pena perseguir. Melhorias na eficiência resultantes do mero "enxugamento", do aumento da intensidade do trabalho, de intervalos mais curtos e de margens mais apertadas são algo completamente diferente. [...] Que a economia em um lugar pode terminar com o aumento das despesas em outro lugar nas contas nacionais é algo que temos visto bastante, enquanto a intensidade do trabalho e a concorrência têm aumentado" (tradução nossa, WAHL, 2011).

O autor chama a atenção aqui para o fato de que as vantagens decorrentes desse tipo de intensificação do trabalho não resistem a uma análise mais ampla e detalhada. Diversos estudos realizados no contexto das reformas gerenciais aplicadas aos serviços de saúde demonstram que, a intensificação do trabalho alcançada a partir desses processos, está frequentemente associada à piora da saúde dos trabalhadores e ao aumento da insatisfação relacionada aos processos de trabalho (UGALDE; HOMEDES, 2005; BLANCH; STECHER, 2009; MORELLI; SAPEDE; SILVA, 2015). Há também evidências de que tais processos são percebidos pelos trabalhadores como responsáveis por uma piora na qualidade dos serviços (UGALDE; HOMEDES, 2005; BLANCH; STECHER, 2009; RIMMER, 2015; MCCARTHY, 2015) ${ }^{113}$.

Ou seja, ainda que façamos a avaliação do processo apenas a partir do setor saúde, os problemas são bastante evidentes: há não somente o maior adoecimento dos trabalhadores do setor, há também as diversas distorções que esse modo de organizar o trabalho pode imprimir aos serviços de saúde.

A análise dos documentos deixa evidente, aliás, que uma das principais maneiras pela qual se atinge a maior extração de trabalho nesses serviços está relacionada com a tática de diminuir a estabilidade do servidor público. Em um contexto em que os trabalhadores contratados pelo Estado, em regime estatutário, gozariam de certa estabilidade e de melhores condições para a organização política e sindical, a terceirização seria fundamental pra quebrar resistências. Um documento do Ministério do Planejamento, Orçamento e Gestão que trata sobre as Fundações Estatais de Direito Privado, outro modelo de gestão que também visa implementar aspectos da gestão privada no serviço público, deixa esse aspecto bastante claro:

113 Ver essa discussão em Ballarotti (2015). 
A estabilidade está relacionada ao vínculo estatutário, estabelecido mediante aprovação em concurso público e não se estende, inclusive, aos servidores ocupantes exclusivamente de cargos em comissão de direção ou assessoramento, cuja natureza de livre provimento permite, a qualquer tempo, a sua exoneração (MPOG, 2007, p. 19).

Em seguida, o documento esclarece:

Vale lembrar que os regimes estatutários, caracterizados pela estruturação em carreiras está voltado para a promoção dos valores de governança, especialmente daqueles que a sociedade considera importantes para os agentes responsáveis pela aplicação da lei ou realização da vontade coletiva. [...] Por outro lado, nas áreas em que atua de forma complementar à iniciativa privada, é indispensável que o Estado possa aplicar o regime de emprego celetista, mais flexível e aberto à inovação e à especialidade, atributos essenciais a quem atua em ambiente concorrencial e precisa garantir a qualidade dos serviços e a incorporação de novas tecnologias geradas para o setor (MPOG, 2007, p. 19).

No caso específico do município de São Paulo, em que, desde o PAS, as parcerias com instituições privadas foram realizadas para gerir serviços que já contavam com servidores públicos, se estabeleceu também um ambiente de trabalho conflitivo. Aqui, mais um depoimento do estudo de Ballarotti (2015) serve como exemplo:

"[...] no local onde eu fazia pediatria era estadual e foi municipalizado. E lá é onde vieram as equipes, 3 equipes [de PSF]. [...] Eu já estava lá e na mesma unidade, comecei PSF lá. [...] Foi tudo muito complicado ali, porque a gente era uma unidade do Estado que foi municipalizada. A gente tinha funcionários ali que eram contratados federal, concurso federal. A enfermeira da minha equipe era com contrato federal. Era uma bagunça. Depois veio o AMA. Foi muito difícil trabalhar lá, PSF ali..." [...] "Era uma unidade mista. [...] Era conflituoso pra caramba. E até para os pacientes era complicado. [...] Foi complicado. A parte dos pacientes, dos colegas" (BALLAROTTI, 2015, p. 52).

A seguir, com base também em outras entrevistas, a autora conclui:

"Os médicos entrevistados trouxeram a percepção de como essa convivência de diferentes modelos de atenção na APS pode se caracterizar, 'confusão', 'bagunça', 'conflituoso', 'complicado'” (BALLAROTTI, 2015, p. 53).

Antunes e Druck (2013) apontam como as terceirizações, e também essa convivência entre trabalhadores de diferentes "categorias", pode criar divisões e rivalidades, assim como também podem acabar por ter um efeito de enfraquecer o potencial de articulação política e sindical dos trabalhadores:

No que se refere ao coletivo de trabalhadores, a terceirização fragmenta, divide, aparta, desmembra as identidades coletivas, individualiza e cria 
concorrência entre os que trabalham muitas vezes no mesmo local, nas mesmas funções, mas estão separados de fato e simbolicamente pelo crachá diferente e pelos diferentes uniformes, que identificam os de primeira e de segunda categoria. Um apartheid que tem implicação direta sobre a potencialidade da ação coletiva e sindical, como um outro campo do trabalho, à medida que a terceirização impõe uma pulverização dos sindicatos, ocorrendo muitas vezes que numa mesma empresa os diferentes setores terceirizados, a exemplo da limpeza, vigilância, alimentação, manutenção, etc., congregam trabalhadores que estão enquadrados e representados por diferentes sindicatos (ANTUNES; DRUCK, 2013, p. 220-1).

A partir do que foi discutido aqui, a intensificação na extração de trabalho excedente alcançada pelas terceirizações parece ser alcançada principalmente a partir da precarização do trabalho. Apesar da retórica muitas vezes utilizada da "diminuição dos gastos públicos", o que se observa na realidade é que os recursos "economizados" nesse tipo de reforma acabam por remunerar os rentistas, na forma do pagamento de juros sobre a dívida pública.

Aqui se coloca a hipótese, portanto, de que a privatização da gestão dos serviços públicos de saúde, enquanto tática para diminuir a resistência dos trabalhadores e aumentar a extração de trabalho excedente, se relaciona às maiores pressões exercidas, na fase atual do capitalismo, pela remuneração do capital portador de juros. Sendo assim, a terceirização parece ser a maneira pela qual o Estado intenta transferir, aos trabalhadores desses serviços, parte das pressões que sofre pela remuneração do capital-propriedade, via pagamento dos juros da dívida pública ${ }^{114}$.

\footnotetext{
114 No capítulo XXIII do livro III de O Capital, Marx aborda a tensão que se estabelece entre o capitalpropriedade e o capital-função (Ver seção 1.2.1 desse trabalho). Esse e outros conceitos utilizados nessa seção se aplicam, na obra marxiana, ao ciclo de reprodução ampliada do capital, não sendo diretamente aplicáveis à produção de serviços públicos por entidades que não podem aferir lucros. Ainda que tais serviços não estejam diretamente implicados num processo de reprodução do capital do tipo D - M - D', ou seja, ainda que não impliquem a criação direta de mais valor, é possível afirmar que a intensificação da extração de trabalho excedente nesses serviços garante ao Estado a realização de maiores "superávits primários". Em outras palavras, garante um maior excedente financeiro a ser utilizado para a remuneração do capital portador de juros. Consideramos que essa situação, e também a proeminência do capital financeiro em ambos os processos, justificam a utilização desses conceitos aqui no sentido de traçar um paralelo entre as reformas gerenciais e os processos de reestruturação produtiva que as inspiraram.
} 


\section{Considerações Finais}

A reforma do aparelho de Estado implementada no Brasil a partir do início dos anos 1990 foi muitas vezes defendida como processo fundamental para viabilizar a consecução dos direitos sociais. Somente aumentando a capacidade de realizar os serviços públicos com eficiência, o país seria capaz de viabilizar grandes feitos, como a garantia de assistência à saúde para todos seus cidadãos. Não somente isso, a descentralização desses serviços - que passariam do Estado para a iniciativa privada - estaria inserido na defesa da coisa pública e seria passo importante para democratizar o Estado (BRASIL, 1995).

Como discutimos no último capítulo, no entanto, no caso específico dos serviços públicos de Atenção Primária a Saúde da cidade de São Paulo, não há evidências de que tais promessas tenham sido cumpridas.

O suposto "ganho de eficiência", com um maior número de consultas realizadas por recurso empregado, ainda precisa ser mais bem avaliado nos termos do seu real efeito na saúde da população. Diante das denúncias de trabalhadores e usuários do SUS, exemplificadas por estudos como o de Ballarotti (2015) - mas também presentes nos fóruns institucionais, na mídia e nas ruas - as distorções causadas pelo modo pelo qual o número dessas consultas foi incrementado devem ser mais bem investigadas.

A suposta maior participação da comunidade, defendida tanto pelo governo federal (do PSDB) que propôs o modelo (BRASIL, 1995), como também pelo governo municipal (do PT) que implantou modelo semelhante para garantir a expansão da APS (SOUSA, 2003; INOJOSA, 2003), também não se confirmou. Passados mais de 10 anos da aprovação da lei das OS no município de São Paulo, os únicos mecanismos que garantem a participação do usuário (ainda que não esteja clara a importância exata dessa participação), não tem relação com o modelo das OS, como os conselhos gestores das unidades e a ouvidoria SUS.

Ao contrário do prometido, portanto, a adoção do modelo de gestão gerencialista não representou a melhora dos serviços públicos ou a "publicização" do Estado brasileiro. Ao contrário, a história tem mostrado de forma cada vez mais clara os agudos interesses particulares que se escondem por trás desse tipo de projeto. 
As propostas políticas de diminuição do Estado e cessão dos serviços públicos à iniciativa privada (assim como as exigências por menos direitos trabalhistas e menores controles aos fluxos financeiros) são produtos notórios do movimento político e ideológico chamado de Neoliberalismo. Como demonstra Harvey (2014), o Neoliberalismo se configura como uma ofensiva das classes proprietárias que tem o objetivo de reconquistar parte da dominância política e econômica perdidas no pós-guerra. É razoável afirmar, assim, que os interesses representados por esse tipo de política, de forma geral, não são os interesses de todos, mas sim os interesses bastante particulares das classes proprietárias.

Como discutido no Capítulo 1, a partir da década de 1970, as classes proprietárias tinham de lidar com o relativo enfraquecimento do seu poder político ao mesmo tempo em que enfrentavam o agravamento da crise crônica de sobreacumulação. As políticas neoliberais refletem a tentativa de enfrentamento de ambos os desafios.

A instrumentalização do Estado com o objetivo de superar as barreiras à acumulação capitalista não é exatamente uma novidade, longe disso ${ }^{115}$. Como vimos no Capítulo 2, a própria consecução do direito à assistência à saúde esteve, no Brasil, intimamente ligada aos movimentos da reprodução do capital.

A principal maneira pela qual os trabalhadores formais acessariam a assistência à saúde, durante a maior parte do século $X X$, seria através da previdência. As primeiras Caixas de Aposentadorias e Pensões, criadas na década de 1920, já previam o acesso a alguns serviços de assistência médica. Muito embora as primeiras CAPs tenham sido resultado direto da luta política dos trabalhadores, não se passaria muito tempo até que os recursos previdenciários fossem utilizados para financiar projetos rurais, de industrialização e infraestrutura. $\mathrm{Na}$ década de 1930, a ditadura de Vargas trataria de centralizar o processo; enquanto era ampliado o número de trabalhadores cobertos pelos IAPs, o acesso ao pagamento de aposentadorias e a serviços de saúde passava a ser mais restrito. $\mathrm{O}$ resultado foi a criação de superávits de até $70 \%$ do orçamento, e de um "importante

115 O Imperialismo das nações centrais do último quarto do século XIX e o próprio keynesianismo do pós-Guerra são dois exemplos bastante diversos, mas ainda assim bastante representativos de como os Estados estiveram historicamente a serviço das classes proprietárias na superação das crises e na garantia da reprodução do capital. 
mecanismo de acumulação financeira em mãos do Estado" (OLIVEIRA; TEIXEIRA, 1986, p. 142).

A partir de meados da década de 1960, na vigência de outra ditadura, mais uma vez a assistência a saúde estaria mais explicitamente ligada aos interesses capitalistas. Enquanto os recursos previdenciários continuariam a ser utilizados para financiar grandes obras de infraestrutura, o grande beneficiado do período seria o próprio setor privado da saúde. Financiada com recursos públicos, a rede de assistência médica do período militar priorizava a contratação de serviços privados e a realização de convênios com empresas. Principal garantidora do crescimento do setor privado de saúde no Brasil, a rede de assistência previdenciária notabilizou-se pela sua perdularidade e ineficiência.

Se de um lado a assistência médica previdenciária era submetida à "lógica dos negócios", de outro lado estavam os serviços da chamada "Saúde Pública"; com uma rede verticalizada e fragmentada. Ocupava-se pouco da assistência individual e era mais voltada para ações populacionais. Seria a partir desses dois sistemas que se daria mais tarde a construção do SUS.

Coincidentemente ou não, a crise da dívida pública seria um importante estímulo para a reforma do sistema de saúde. Em plena "crise do milagre", a combinação de gastos excessivos com a precariedade do acesso faria com que a necessidade de reformas fosse praticamente um consenso. Mesmo antes da Nova República, o governo Figueiredo (1979-1985) buscaria realizar reformas, com o Prev-saúde e o Plano do Conasp, como tratado no capítulo 2 desse trabalho.

Diferente do que é normalmente discutido, já na primeira metade da década de 1980 um projeto do Banco Mundial começa a influenciar a saúde no Brasil, mais especificamente no estado de São Paulo. O Programa Metropolitano de Saúde, projeto que já previa a gestão privada dos serviços públicos (IBAÑEZ et al., 2001), recebeu 55 milhões de dólares do Banco Mundial, a partir de acordo assinado em dezembro de 1984 (RIZZOTTO, 2012, p. 135). Apesar de não ter sido finalizado, o PMS acabou se tornando importante precursor para o projeto das Organizações Sociais em âmbito estadual, colocado em prática uma década mais tarde. 
Seria apenas na década de 1990, no entanto, que as políticas do Banco Mundial para a saúde teriam maior influência no país. Somente com a eleição de Collor as políticas neoliberais tomariam proeminência, e o país seria preparado para cumprir o seu papel de "plataforma de valorização financeira internacional" (PAULANI, 2008).

Da mesma maneira como esteve ligada aos movimentos da reprodução capitalista no passado, a configuração da assistência à saúde passaria, então, a ser atravessada pela ascensão da finança.

Nesse período de dominância do capital portador de juros, o projeto Neoliberal se apresentaria como a maneira renovada de utilizar o aparelho Estatal em benefício da acumulação capitalista. No conjunto dessas políticas, podem ser identificados três importantes eixos: a diminuição dos custos com a remuneração do trabalho; a criação ou liberação de novos loci para a reprodução do capital; a utilização do orçamento do Estado para garantir a remuneração do capital financeiro ${ }^{116}$.

Como vimos no Capítulo 1, medidas importantes foram tomadas em todos os três eixos: buscou-se diminuir os custos do trabalho, com o achatamento dos salários; abriu-se novas áreas para a expansão capitalista, por meio de um extenso programa de privatização de empresas públicas; garantiram-se recursos do Estado para a remuneração do capital financeiro, com medidas como as reformas da previdência e a Lei de Responsabilidade Fiscal.

De certa maneira, a privatização dos serviços públicos pode ser identificada com os três eixos.

A implementação das OS visa à diminuição dos custos com o trabalho. Como vimos no Capítulo 3, não somente a busca por colocar os servidores públicos em posição de maior vulnerabilidade é objetivo declarado dos modelos de gestão desse tipo, como os próprios servidores sentem-se, no ambiente de trabalho, assediados e ameaçados.

116 A consecução desses objetivos não foi buscada somente a partir de iniciativas econômicas e também não se confinou aos limites da politica institucional, as táticas adotadas foram muitas vezes absolutamente violentas. A ditadura chilena liderada por Augusto Pinochet, primeiro governo em que as politicas neoliberais teriam proeminência, é um exemplo dessa situação (HARVEY, 2014). 
Em relação à liberação de novos loci para a reprodução do capital, apesar de a privatização da gestão dos serviços realizados por meio das OS não permitir a realização de lucros, transfere-se uma enorme quantidade de recursos financeiros para o setor privado. Os superávits alcançados por essas Organizações Sociais podem inclusive ser aplicados (temporariamente) nos mercados financeiros ${ }^{117}$.

É o terceiro eixo, no entanto, aquele que envolve a tentativa de garantir a remuneração do capital financeiro, que parece ser o mais importante aqui. Ao atuar de forma concertada com outros mecanismos, como a Lei de Responsabilidade Fiscal, a terceirização dos serviços públicos se insere em uma estratégia maior de submissão do orçamento do Estado aos imperativos da finança.

O principal aspecto a ser considerado aqui, no entanto, não se refere a um suposto ganho de eficiência, mas sim à desresponsabilização do Estado acerca do seu papel de conceder uma assistência à saúde de qualidade.

A evidente insuficiência dos mecanismos de participação dos usuários e 0 ativo desestímulo à participação dos trabalhadores cria uma grande distância entre a realidade dos serviços e núcleo dirigente do Estado. Essa barreira que se cria, entre a opinião popular e o centro do poder estatal, permite que se continue a oferecer serviços de má qualidade e cujo acesso é insuficiente. É como se o modelo tentasse deliberadamente afastar do funcionamento do Estado a própria participação popular.

E não somente isso. É também essa distância entre a definição das metas (pensar) e a sua aplicação (fazer) que permite o tipo de distorção descrita na seção 3.2.1 do Capítulo 3. Ainda que os indicadores de desempenho possam se tornar instrumentos importantes para garantir bons serviços de saúde, efetividade e o respeito à coisa pública, é necessário que tais indicadores sejam construídos junto aos trabalhadores e usuários, num processo dinâmico. É fundamental que se realize a constante avaliação e revisão, não só desses indicadores, mas de seus efeitos concretos.

\footnotetext{
117 Como apontamos no Capítulo 3, os últimos Contratos de Gestão divulgados pela PMSP regulam a aplicação desses recursos, evitando o seu uso abusivo. Apesar disso, tal mecanismo de controle está ausente nos Contratos de Gestão mais antigos, e provavelmente não se aplicam aos convênios, cujos controles são menos rigorosos.
} 
Por final, é preciso dizer: ainda que em situações adversas, há também experiências positivas.

O SUS em São Paulo, assim como no restante do país, expressa no seu cotidiano as agruras impostas por um Estado capturado pelos interesses das classes proprietárias; traz em si as marcas da escassez e do descaso. Mas não traz somente essas marcas. Traz em si também as marcas das lutas do povo, na sua busca por viver de forma menos sofrida. Como não poderia deixar de ser, traz em si as marcas das lutas cotidianas de incontáveis trabalhadores; aqueles que tem sido absolutamente dedicados à construção do direito à saúde. 


\section{Referências Bibliográficas}

AGENCIA ESTADO. Haddad e Serra fazem 'guerra' sobre contratação de organizações sociais. Último Segundo, 2012. Disponivel em: <http://ultimosegundo.ig.com.br/politica/2012-10-25/haddad-e-serra-fazem-guerrasobre-contratacao-de-organizacoes-sociais.html>. Acesso em: 1 julho 2016.

ANTUNES, Ricardo; DRUCK, Graça. A terceirização como regra? Revista do Tribunal Superior do Trabalho, Brasília, v. 79, n. 4, p. 214-31, out/dez 2013.

AROUCA, Sérgio. O Dilema Preventivista: contribuição para a compreensão e crítica da medicina preventiva. Rio de Janeiro: Fiocruz, 2003.

BAHIA, Ligia. O SUS e os desafios da universalização do direito à saúde: tensões e padrões de convivência entre o público e o privado no sistema de saúde brasileiro. In: LIMA, Nísia Trindade, et al. Saúde e democracia: história e perspectivas do SUS. [S.I.]: Fiocruz, 2005. p. 407-49.

BALLAROTTI, Bruna. Governo Dilma desrespeita o controle social mais uma vez. Frente Nacional Contra a Privatização da Saúde, 2012. Disponivel em: <http://www.contraprivatizacao.com.br/2012/02/governo-dilma-desrespeita-ocontrole.html>. Acesso em: 05 março 2016.

BALLAROTTI, Bruna. Percepção de médicos da estratégia de saúde da família do município de são paulo: o cotidiano do trabalho médico sob a gestão de organizações sociais. São Paulo: Unifesp. Dissertação de Mestrado, 2015.

BANCO CENTRAL EUROPEU. Financial assistance measures in the euro area from 2008 to 2013: statistical framework and fiscal impact. European Central Bank, 2015. Disponivel em: <https://www.ecb.europa.eu/pub/pdf/scpsps/ecbsp7.en.pdf>. Acesso em: 09 julho 2016.

BANCO MUNDIAL. Salud: documento de política sectorial. Washinton DC. 1975.

BANCO MUNDIAL. Brasil: novo desafio à saúde do adulto. Washington DC. 1991.

BANCO MUNDIAL. A organizaçäo, prestaçäo e financiamento da saúde no Brasil: uma agenda para os anos 90. Washington DC. 1995. 
BARBOSA, Nelson Bezerra; ELIAS, Paulo Eduardo Mangeon. As organizações sociais de saúde como forma de gestão público/privado. Ciência \& Saúde Coletiva, v. 15 , n. 5 , p. 2483-95, agosto 2010.

BEHRING, Elaine; BOSCHETTI, Ivanete. Política social: fundamento e história. São Palo: Cortez, 2006.

BIANCARELLI, Aureliano. Erundina constrói 6 hospitais, mas não consegue adesão dos médicos. Folha de São Paulo, 1996. Disponivel em: <http://www1.folha.uol.com.br/fsp/1996/10/20/caderno_especial/3.html>. Acesso em: 20 junho 2016.

BLANCH, Josep M; STECHER, Antonio. La empresarización de universidades y hospitales. In: WITTKE, Tommy; MELOGNO, Pablo Psicología y Organización del trabajo. Montevideo: Psicolibros, 2009. p. 191-209.

BRAGA, José Carlos de Souza; PAULA, Sérgio Góes. Saúde e previdência: estudos de política social. 2ª . ed. São Paulo: Hucitec, 1986.

BRASIL. Decreto № 86.329, de 2 de setembro de 1981, 1981. Disponivel em: <http://www2.camara.leg.br/legin/fed/decret/1980-1987/decreto-86329-2-setembro1981-436022-publicacaooriginal-1-pe.html>. Acesso em: 20 de março de 2016.

BRASIL. Plano diretor da reforma do aparelho do estado. Câmara da Reforma do Estado, Ministério da Administração Federal e Reforma do Estado. Brasilia. 1995.

BRASIL. Plano diretor da reforma do aparelho do estado. Câmara da Reforma do Estado, Ministério da Administração Federal e Reforma do Estado. Brasilia. 1995.

BRASIL. Plano diretor da reforma do aparelho do estado. Ministério da Administração e Reforma do Estado. Brasilia. 1995.

BRASIL. Política Nacional de Atenção Básica. Departamento de Atenção Básica, Secretaria de Atenção à Saúde, Ministério da Saúde. Brasília. 2012.

BRASIL. Medida Provisória № 665, de 30 de dezembro de 2014, 2014. Disponivel em: <http://www.planalto.gov.br/ccivil_03/_Ato2011-2014/2014/Mpv/mpv665.htm>. Acesso em: 10 de janeiro de 2015. Altera a Lei no 7.998, de 11 de janeiro de 1990, que regula o Programa do Seguro-Desemprego, o Abono Salarial e institui o Fundo 
de Amparo ao Trabalhador - FAT, altera a Lei no 10.779, de 25 de novembro de 2003, que dispõe sobre o seguro desemprego para 0.

CALLINICOS, Alex. Bonfire of illusions: the twin crises of the liberal world. Cambridge: Polity, 2010.

CALLINICOS, Alex. Deciphering Capital: Marx's Capital and its destiny. London: Bookmarks Publications, 2014.

CAMPOS, Claudia Valentina de Arruda; MALIK, Ana Maria. Satisfação no trabalho e rotatividade dos médicos do Programa de Saúde da Família. Revista de Administração Pública, v. 42, n. 2, p. 347-368, 2008.

CARDOSO, Felipe Monte. A saúde entre os negócios e a questão social: Privatização, Modernização e Segregação na Ditadura Civil-Militar (1964-1985). 1ª . ed. São Paulo: Hucitec, 2013.

CARVALHO, Fernando Cardim de. Bretton Woods aos 60 anos. Novos Estudos Cebrap, v. 70, p. 51, 2004.

CHERNOW, Ron. The house of Morgan: an American banking dynasty and the rise of modern finance. Nova lorque: Grove Press, 2001.

CHESNAIS, François. Mundialização Financeira. 1a․ ed. São Paulo: Xamã, 1998.

CHESNAIS, François. Capital portador de juros: acumulação, internacionalização, efeitos econômicos e políticos. In: CHESNAIS, François A Finança Mundializada. 1‥ ed. São Paulo: Boitempo, 2005. p. 35-67.

CHESNAIS, François. A proeminência da finança no seio do "capital em geral", o capital fictício e o movimento contemporâneo de mundialização de capital. In: CHESNAIS, François A Finança Capitalista. 1. ed. São Paulo: Alameda, 2010.

CHESNAIS, François. A Proeminência da Finança no Seio do Capital em Geral, o Capital Fictício e o Movimento Contemporâneo de Mundialização do Capital. In: BRUNHOFF, Suzanne de, et al. A finança capitalista. São Paulo: Alameda, 2010. p. $95-182$. 
CNBC. Brexit endangers UK state pensions, NHS,Prime Minister David Cameron warns. CNBC, 12 de junho de 2016. Disponivel em: <http://www.cnbc.com/2016/06/12/brexit-endangers-uk-state-pensions-nhs-primeminister-david-cameron-warns.html>. Acesso em: 09 julho 2016.

COHN, Amélia. O sistema unificado e descentralizado de saúde: descentralização ou desconcentração. Sao Paulo em Perspectiva, v. 1, n. 3, p. 55-58, 1987.

COHN, Amélia; ELIAS, Paulo Eduardo Mangeon. 0 público e o privado na saúde: o PAS em São Paulo. São Paulo: Cortez, 1999.

COMPARATO, Fábio Konder; TORRES, Heleno Taveira; PINTO, Élida Graziane, SARLET, Ingo Wolfgang. Financiamento dos direitos à saúde e à educação: mínimos inegociáveis. Revista Consultor Jurídico, 2016. Disponivel em: $<$ http://www.conjur.com.br/2016-jul-27/financiamento-direitos-saude-educacaominimos-inegociaveis>. Acesso em: 27 julho 2016.

CONTREIRAS, Henrique; MATTA, Gustavo Corrêa. Privatização da gestão do sistema municipal de saúde por meio de Organizações Sociais na cidade de São Paulo, Brasil: caracterização e análise da regulação. Cadernos de Saúde Pública, v. 31, n. 2, p. 285-297, 2015.

CORDEIRO, Hésio. As empresas médicas: as transformaçöes capitalistas da prática médica. 1a․ ed. Rio de Janeiro: Graal, 1984.

CORNELLI, Marcela. A lógica perversa da dívida e o orçamento de 2015. Auditoria Cidadã da Dívida, 13 de março de 2015. Disponivel em: <http://www.auditoriacidada.org.br/blog/2015/03/13/a-logica-perversa-da-divida-e-oorcamento-de-2015/>. Acesso em: 09 julho 2016.

CORSALETTE, Conrado. Clínica de Kassab é posto de saúde reformado. Folha de São Paulo, $2008 . \quad$ Disponivel em: <http://www1.folha.uol.com.br/fsp/brasil/fc2210200804.htm>. Acesso em: 01 julho 2016.

COSTA, Nilson do Rosário. Lutas urbanas e controle sanitário: origens das políticas de saúde no Brasil. [S.I.]: Vozes, 1986. 
COSTA, Nilson do Rosário; RIBEIRO, José Mendes. Estudo comparativo do desempenho de hospitais em regime de organização social, Rio de Janeiro, 2004.

CRUZ, Paulo Davidoff. Divida externa e polítca econômica. 1a. ed. São Paulo: Brasiliense, 1984.

DANTAS, André Vianna. Do socialismo à democracia: dilemas da classe trabalhadora no brasil recente e o lugar da reforma sanitária brasileira. Rio de Janeiro: Tese de Doutorado. Universidade Federal do Rio de Janeiro - UFRJ, 2014.

DONNANGELO, Maria Cecília F; PEREIRA, Luiz. Saúde e Sociedade. São Paulo: Duas Cidades, 1976.

DONNINI, Osvaldo Antonio. A reorganização da gestão de saúde em São Paulo. In: SOUSA, Maria Fátima; MENDES, Aquilas Nogueira Tempos radicais da saúde em São Paulo: a construção do SUS na maior cidade brasileira. São Paulo: Hucitec, 2003. p. 31-42.

DUMÉNIL, Gerárd; LÉVY, Dominique. O Neoliberalismo sob Hegemonia Norteamericana. In: CHESNAIS, François A Finança Mundializada. 1a. ed. São Paulo: Boitempo, 2005. p. 88-89.

DUMÉNIL, Gerárd; LÉVY, Dominique. A Finança Capitalista: Relações de produção e relações de classe. In: CHESNAIS, François A Finança Capitalista. 1. ed. São Paulo: Alameda, 2010.

DUMÉNIL, Gérard; LÉVY, Dominique. A crise do neoliberalismo. 1. ed. São Paulo: Boitempo, 2014.

EICHENGREEN, Barry J. Globalizing capital: a history of the international monetary system. (Kindle) 2 2⿳a ed. Princeton: Princeton University Press, 2008.

ELIAS, Paulo Eduardo Mangeon. PAS: um perfil neoliberal de gestão de sistema público de saúde. Estudos avançados, São Paulo, v. 13, n. 35, p. 125-37, abril 1999.

EQUIPE DILMA ROUSSEF. Dilma, 2014. Disponivel em: $<$ http://www.dilma.com.br/noticia/dilma-sobre-mexer-nos-direitos-trabalhistas-nemque-a-vaca-tussa-410>. Acesso em: 10 de janeiro de 2015. 
FAGNANI, E. Política Social e Pactos Conservadores no Brasil: 1964/1992. Economia e Sociedade, Campinas, n. 8, p. 183-238, 1997.

FALEIROS, Vicente de Paula et al. A construção do SUS: histórias da reforma Sanitária e do Processo participativo. Brasilia: Ministério da Saúde, 2006.

FAUSTO, Márcia Cristina Rodrigues. Dos programas de medicina comunitária ao

Sistema Único de Saúde: uma análise histórica da atenção primária na política de saúde brasileira. [S.I.]: [s.n.], 2005.

FERREIRA JUNIOR, Walter Cintra. Gerenciamento de hospitais estaduais paulistas por meio das organizações sociais de saúde. Revista de Administração, Rio de Janeiro, v. 37, n. 2, p. 243-264, mar /abr 2003.

FERREIRA, Mariana Ribeiro Jansen. Tendências e contratendências de mercantilização: as reformas dos sistemas de saúde alemão, francês e britânico. São Paulo: Tese de Doutorado. Universidade de São Paulo, 2016.

FIPE. Proposta de um novo modelo para a saúde. Fundação Instituto de Pesquisas Econômicas da USP. São Paulo. 1995.

FOLHA DE SÃO PAULO. FHC ordena demissão em massa a partir de hoje. Folha de São Paulo, São Paulo, 2 junho 1995. http://www1.folha.uol.com.br/fsp/1995/6/02/brasil/5.html.

FOLHA DE SÃO PAULO. Prefeitura diz que modelo poupa dinheiro. Folha de São Paulo, $2008 . \quad$ Disponivel em: <http://www1.folha.uol.com.br/fsp/brasil/fc2210200805.htm>. Acesso em: 01 jul. 2016.

FOUCAULT, Michel. O Nascimento da Clínica. 7a․ ed. Rio de Janeiro: Forense Universitária, 2011.

FOUCAULT, Michel. O nascimento da medicina social. In: FOUCAULT, Michel Microfísica do Poder. São Paulo: Paz e Terra, 2015. p. xx.

FRANCO, Gustavo. A inserção externa e o desenvolvimento. Revista de economia política, v. 18, n. 3, p. 71, julho 1998. 
FRENTE NACIONAL CONTRA A PRIVATIZAÇÃO DA SAÚDE. Contra fatos não há argumentos que sustentem as Organizações Sociais no Brasil. Frente Nacional Contra a Privatização da Saúde, 2012. Disponivel em: $<$ https://drive.google.com/file/d/OB3SRQLv1tEAVOE9WUDAtYXlubnc/view?pref=2\&> . Acesso em: junho 2016.

GIAMBIAGI, Fábio et al. Economia Brasileira Contemporânea (1945-2004). 2ª̣. reimpressão. ed. Rio de Janeiro: Elsevier, 2005.

GIOVANELLA, Ligia; MENDONÇA, Maria Helena Magalhães de. Atenção Primária à Saúde: seletiva ou coordenadorados cuidados? Rio de Janeiro: CEBES, 2012.

GODDARD, Maria; MANNION, Russell; SMITH, Peter C. The NHS performance framework: taking account of economic behaviour. York: Centre for Health Economics, University of York, 1998.

HARVEY, David. O "novo" imperialismo: acumulação por espoliação. Socialist Register, 40, 2004. 63-87.

HARVEY, David. The Limits to Capital (new and fully updated edition). Londres e Nova lorque: Verso, 2006.

HARVEY, David. O enigma do capital e as crises do capitalismo. 1‥ ed. São Paulo: Boitempo, 2011.

HARVEY, David. Para entender O capital. 1‥ ed. São Paulo: Boitempo, 2013.

HARVEY, David. O novo Imperialismo. 7ª . ed. São Paulo: Edições Loyola, 2013a.

HARVEY, David. Para entender O capital, livro 1. São Paulo: Boitempo, 2013b.

HARVEY, David. O Neoliberalismo: história e implicações. 5ª ed. São: Loyola, 2014.

HARVEY, David. Para entender O capital: Livros II e III. 1a. ed. São Paulo: Boitempo, 2014.

HOBSBAWM, Eric. Era dos Extremos: o breve século XX: 1914-1991. 2ª ed. São Paulo: Companhia das Letras, 1995. $99 \mathrm{p}$. 
IBAÑEZ, Nelson et al. Organizações sociais de saúde: o modelo do Estado de São Paulo. Ciência \& Saúde Coletiva, v. 6, n. 2, p. 391-404, 2001.

IBAÑEZ, Nelson; NETO, Gonzalo Vecina. Modelos de gestão e o SUS. Ciência \& Saúde Coletiva, São Paulo, v. 12, Novembro 2007.

IBGE. Perfil estatístico de crianças e mães no Brasil: Situação de Saúde - 1981. [S.I.]. 1984.

IBGE. Pesquisa Nacional de Saúde 2013: percepção do estado de saúde, estilos de vida e doenças crônicas: Brasil, grandes regiões e unidades da federação. [S.I.]. 2014.

IBGE. Cidades. IBGE, $2015 . \quad$ Disponivel em: $<$ http://www.cidades.ibge.gov.br/xtras/perfil.php?lang=\&codmun=355030\&search=sa o-paulo|sao-paulo>. Acesso em: 24 julho 2016.

IBGE. 2015 em relação a 2014, 2016. Disponivel em: <http://www.ibge.gov.br/home/presidencia/noticias/imprensa/ppts/000000253650031 12016502503588543. pdf $>$. Acesso em: 09 de julho de 2016.

INOJOSA, Rose Marie. Intersetorialidade e compromisso social na metrópole paulistana. In: SOUSA, Maria Fátima; MENDES, Áquilas Nogueira Tempos radicais da saúde em São Paulo: a construção do SUS na maior cidade brasileira. São Paulo: Hucitec, 2003. p. 93-108.

JORNAL DA BAND. Hospital dispensava idosos e internava jovens para bater meta. Jornal da Band, São Paulo, 5 dezembro 2014. http://noticias.band.uol.com.br/jornaldaband/videos/2014/12/05/15302472-hospitaldispensava-idosos-e-internava-jovens-para-bater-meta.html.

JORNAL DO SIMESP. Butantã sofre com mudança na gestão das UBSs. Jornal do Simesp, São Paulo, maio 2016. 4.

JUNQUEIRA, Virginia. "Saúde na Cidade de Säo Paulo de 1989 a 2000." Observatório dos direitos do cidadäo: acompanhamento e análise das políticas públicas da cidade de Säo Paulo. São Paulo: Pontifica Universidade Católica de São Paulo. Instituto Pólis, v. 3, 2002. 
KLIMAN, Andrew. The Failure of Capitalist Production: Underlying Causes of the Great Recession. London: Pluto, 2012.

KLIMAN, Andrew. The great recession and Marx's crisis theory. American Journal of Economics and Sociology, v. 74, n. 2, 2015.

LESSA, Sérgio. Trabalho produtivo e improdutivo. Dicionário da Educação Profissional em Saúde, 2009. Disponivel em: <http://www.sites.epsjv.fiocruz.br/dicionario/verbetes/traproimp.html>. Acesso em: 30 janeiro 2015.

LIMA, Julio Cesar França. O Banco Mundial, a Organização Mundial de Saúde e o "novo universalismo" ou a "cobertura universal de saúde". In: PEREIRA, João Márcio Mendes; PRONKO, Marcela A demolição de direitos: um exame das políticas do Banco Mundial para a educação e a saúde (1980-2013). Rio de Janeiro: Escola Politécnica de Saúde Joaquin Venâncio, 2015. p. 233-54.

LIMA, Nísia Trindade; FONSECA, Cristina M O; HOCHMAN, Gilberto. A saúde na construção do Estado Nacional no Brasil: reforma sanitária em perspectiva histórica. In: LIMA, Nísia Trindade, et al. Saúde e democracia: história e perspectivas do SUS. Ebook Google. ed. [S.I.]: Fiocruz, 2005. p. 27-58.

MAGNO, Liz Duque; PAIM, Jairnilson Silva. Dos clamores das ruas aos rumores no Congresso: uma análise da conjuntura recente da saúde no Brasil. Revista Eletrônica de Comunicação, Informação \& Inovação em Saúde, v. 9, n. 4, 2015.

MANNION, Russell; BRAITHWAITE, J. Unintended consequences of performance measurement in healthcare: 20 salutary lessons from the English National Health Service. Internal medicine journal, v. 42, n. 5, p. 569-74, 2012.

MARGULIS, Sérgio. O desempenho do governo brasileiro, dos órgãos contratantes, e do Banco Mundial em relação à questão ambiental do programa Polonoroeste. [S.I.]: IPEA, 1991.

MARQUES, Thiago; MENDES, Áquilas. Uma decisão favorável às OSS: impasses à construção do SUS. Domingueira do Idisa, n. 12, 28 junho 2015. Disponível em: http://www.idisa.org.br/img/File/Domingueira\%20da\%20Sa\%C3\%BAde\%20\%20012\%202015\%20-\%2028\%2006\%202015.pdf. 
MARX, Karl. O capital - livro III. 2ª . ed. São Paulo: Nova Cultural, v. IV, 1986a.

MARX, Karl. O capital - livro III. 2ª ed. São Paulo: Nova Cultural, v. V, 1986b.

MARX, Karl. O capital - livro I. 1. ed. São Paulo: Boitempo, 2013.

MARX, Karl. Productive and Unproductive Labour. marxist.org. Disponivel em: $<$ https://www.marxists.org/archive/marx/works/1864/economic/ch02b.htm>. Acesso em: 30 janeiro 2015.

MATTOS, Adriana. Haddad volta a defender a manutenção das organizações sociais. Valor Econômico, 27 de outubro de 2012. Disponivel em: <http://www.valor.com.br/eleicoes2012/2882776/haddad-volta-defendermanutencao-das-organizacoes-sociais>. Acesso em: 01 fevereiro 2016.

MCCARTHY, Mary. Mary McCarthy: Would fewer than 25 consultations a day be a safer model for GPs? The BMJ, 2015. Disponivel em: <http://blogs.bmj.com/bmj/2015/11/04/mary-mccarthy-would-fewer-than-25consultations-a-day-be-a-safer-model-for-gps/>. Acesso em: 25 nov. 2015.

MEDICl, Andre; MURRAY, Robert. Hospital Performance and Health Quality Improvements in São Paulo (Brazil) and Maryland (USA). En Breve, n. 156, 2010.

MELLO, Guilherme Arantes; IBAÑEZ, Nelson; VIANA, Ana Luiza d'Ávila. Um olhar histórico sobre a questão regional e os serviços básicos de saúde no Estado de São Paulo. Saúde e Sociedade, São Paulo, v. 20, n. 4, p. 853-866, 2011.

MENDES, Áquilas. Tempos turbulentos na saúde pública brasileira: impasses do financiamento no capitalismo financeirizado. 1‥ ed. São Paulo: Hucitec, 2012.

MENDES, Áquilas. O subfinanciamento e a mercantilização do SUS no contexto do capitalismo contemporâneo em crise. In: BRAVO, Maria Inês Souza, et al. A mercantilização da saúde em debate: as Organizações Sociais no Rio de Janeiro. Rio de Janeiro: Rede Sirius, v. 1, 2015. p. 12-19.

MENDES, Áquilas; FUNCIA, Francisco. O SUS e seu financiamento. In: MARQUES, Rosa (org.) Sistema Público de Saúde no Brasil: organização e financiamento. Brasília: OPAS/Abres, 2016. no prelo. 
MENDES, Áquilas; WEILLER, José Alexandre B. Renúncia fiscal (gasto tributário) em saúde: repercussões sobre o financiamento do SUS. Saude em Debate, v. 39, p. 491-505, 2015.

MENDES, René; DIAS, Elizabeth Costa. Da medicina do trabalho à saúde do trabalhador. Rev. saúde pública, v. 25, n. 5, p. 341-9, 1991.

MORELLI, Stephanie Giulianne Silva; SAPEDE, Mário; SILVA, Andréa Tenório Correia da. Burnout em médicos da Atenção Primária: uma revisão sistemática. Rev Bras Med Fam Comunidade, Rio de Janeiro, v. 10, n. 34, p. 1-9, Janeiro 2015.

MOROSINI, Liseane. Carlos Gentile de Mello: Um precursor da Reforma Sanitária. Radis, n. 131, p. 29-31, agosto 2013.

MPOG. Projeto Fundação Estatal - Principais Aspectos. Planejamento, Desenvolvimento e Gestão, 2007. Disponivel em: <http://www.planejamento.gov.br/secretarias/upload/Arquivos/seges/fundacao_estat al/arquivos/081005_pfe_arq_proposta.pdf>. Acesso em: 01 de julho de 2016.

NASSUNO, Marianne. O controle social nas organizações sociais no Brasil. In: BRESSER PEREIRA, Luiz Carlos; CUNILL GRAU, Nuria O público não-estatal na reforma do Estado. Rio de Janeiro: FGV, 1999. p. 335-361.

NAVARRO, Vicente. Social class, political power and the state and their implications in medicine. Social Science \& Medicine (1967), v. 10, n. 9, p. 437-57, 1976.

NEW YORK TIMES. Adding Up the Government's Total Bailout Tab. The New York Times, $2011 . \quad$ Disponivel em: <http://www.nytimes.com/interactive/2009/02/04/business/20090205-bailout-totalsgraphic.html?_r=0>. Acesso em: 09 julho 2016.

OCKÉ-REIS, Carlos Octávio. Mensuração dos gastos tributários: o caso dos planos de saúde - 2003-2011. Brasilia: Ipea, 2013. (Nota Técnica, 5).

OLIVEIRA, Fabricio A. A crise do sistema fiscal brasileiro-1965-1983. Campinas: Tese de Doutorado. IFCH-Unicamp, 1985.

OLIVEIRA, Francisco de. Crítica à razão dualista; 0 ornitorrinco. 1‥ ed. São Paulo: Boitempo, 2003. 
OLIVEIRA, Francisco Eduardo Barreto de; BELTRÃO, Kaizô Iwakami; DAVID, Antonio Carlos de Albuquerque. A dívida da União com a previdência social: uma perspectiva histórica, $1999 . \quad$ Disponivel em: <http://repositorio.ipea.gov.br/handle/11058/2708>. Acesso em: 22 de abril de 2016. OLIVEIRA, J A de A; TEIXEIRA, S M F. (Im)previdência social: 60 anos de história da Previdência no Brasil. Petrópolis: Vozes, 1986.

OLIVEIRA, Jaime A. Reformas e reformismo:" democracia progressiva" e políticas sociais (ou" para uma teoria política da reforma sanitária"). Cadernos de Saúde Pública, Rio de Janeiro, v. 3, n. 4, p. 360-87, out/dez 1987.

OLIVEIRA, Jaime A; TEIXEIRA, Sonia M Fleury. (Im)previdência social: 60 anos de história da Previdência no Brasil. Petrópolis: Vozes, 1986.

ORLANDO, José Maria. As parcerias com as Organizações Sociais de Saúde. In: SMS São Paulo construindo o SUS 100\%. São Paulo: [s.n.], 2012. p. 25-36.

PAIM, J et al. O sistema de saúde brasileiro: história, avanços e desafios. The Lancet, v. 377, n. 9779, p. 1778-97, maio 2011.

PAIM, Jairnilson Silva. Reforma Sanitária Brasileira: contribuição para a compreensão e crítica. Salvador: EDUFBA, 2008.

PATARRA, Ivo. O governo Luiza Erundina: cronologia de quatro anos de administração do PT na Cidade de São Paulo, de 1989 a 1992. [S.I.]: Geração Editorial, 1996.

PAULANI, Leda M. Brasil Delivery: servidão financeira e estado de emergência econômico. 1‥ ed. São Paulo: Boitempo, 2008.

PAULANI, Leda; PATO, Christy G. Investimentos e servidão financeira: o Brasil do último quarto de século. In: PAULANI, Leda Brasil delivery: servidão financeira e estado de emergência econômico. 1a. ed. São Paulo: Boitempo, 2008. p. 88.

PINTO, Nicanor R S; TANAKA, Oswaldo Yoshimi; SPEDO, Sandra Maria. Política de saúde e gestão no processo de (re)construção do SUS em município de grande porte: um estudo de caso de São Paulo, Brasil. Cad. Saúde Pública, Rio de Janeiro, v. 25, n. 4, p. 927-38, abril 2009. 
PREFEITURA MUNICIPAL DE SÃO PAULO. Prefeitura implementará novo modelo de gestão de unidades de saúde na cidade. Prefeitura de São Paulo, 2014. Disponivel em: <http://www.capital.sp.gov.br/portal/noticia/4972>. Acesso em: 26 de junho de 2016.

REGO, José Márcio; MARQUES, Rosa Maria. Economia Brasileira. São Paulo: Saraiva, 2013.

RELMAN, Arnold S. The new medical-industrial complex. New England Journal of Medicine, v. 303, n. 17, p. 963-70, 1980.

RIBEIRO, Fátima Aparecida. Atenção primária (APS) e sistema de saúde no Brasil: uma perspectiva histórica. [S.I.]: Tese de Doutorado. Universidade de São Paulo, 2007.

RIMMER, Abi. GPs want longer consultations, BMA survey finds. BMJ, v. 350, p. h1910, abril 2015.

RIZZOTTO, Maria Lucia Frizon. Capitalismo e saúde no Brasil nos anos 90: as propostas do Banco Mundial e o desmonte do SUS. São Paulo: Hucitec, 2012.

ROBERTS, Michael. From Global Slump to Long Depression. International Socialism, London, n. 140, (autumn) 2013.

ROBERTS, Michael. The Global Crawn Continues. International Socialism, n. 147, 2015.

ROUSSEF, Dilma. Portal Brasil, 2015. Disponivel em: <http://www.brasil.gov.br/governo/2015/01/discurso-de-posse.docx/view>. Acesso em: 10 de janeiro de 2015.

SAES, Décio. República do capital: capitalismo e processo político no Brasil. São Paulo: Boitempo, 2001.

SAFATLE, Claudia. Valor Economico, 2012. Disponivel em: $<$ http://www.valor.com.br/cultura/2783388/mae-de-todas-crises-do-brasil>. Acesso em: 7 de fevereiro de 2015. 
SANO, Hironobu; ABRUCIO, Fernando Luiz. Promessas e resultados da nova gestão pública no Brasil: o caso das organizações sociais de saúde em São Paulo. Revista de Administração de Empresas, São Paulo, v. 48, n. 3, p. 64-80, jul / set 2008.

SÃO PAULO (CIDADE). Lei Municipal no 14.132, 24 de janeiro de 2006. Disponivel em:

<http://www3.prefeitura.sp.gov.br/cadlem/secretarias/negocios_juridicos/cadlem/inte gra.asp?alt=25012006L\%20141320000 >. Acesso em: 08 de maio de 2016.

SÃO PAULO (CIDADE). Lei Municipal n 14.664, 04 de janeiro de 2008. Disponivel em:

<http://www3.prefeitura.sp.gov.br/cadlem/secretarias/negocios_juridicos/cadlem/inte gra.asp?alt=05012008L\%20146640000 >. Acesso em: 25 de junho de 2016.

SÃO PAULO (ESTADO). Decreto N. 23.195, de 2 de janeiro de 1985, 1985. Acesso em: 2016 de junho de 20.

SECRETARIA MUNICIPAL DE SAÚDE DE SÃO PAULO. Contrato de Gestão no 012/2008-NTCSS-SMS-G, 2008. Acesso em: 15 de fevereiro de 2016.

SECRETARIA MUNICIPAL DE SAÚDE DE SÃO PAULO. Prestação de Contas do Ano de 2012. Prefeitura de São Paulo, 2012. Disponivel em: <http://www.prefeitura.sp.gov.br/cidade/secretarias/upload/saude/arquivos/prestacao contas/PrestacaoContasSMS_2012.pdf>. Acesso em: 01 julho 2016.

SECRETARIA MUNICIPAL DE SAÚDE DE SÃO PAULO. PORTARIA № 2373/2015SMS.G. Diário Oficial CidadeSP, 30 de dezembro de 2015a. Disponivel em: <http://www.docidadesp.imprensaoficial.com.br>. Acesso em: 15 de fevereiro de 2016.

SECRETARIA MUNICIPAL DE SAÚDE DE SÃO PAULO. Minuta do Contrato de Gestão: Unidades e Serviços da Rede Assistencial da Supervisão Técnica de Saúde. Secretaria Municipal de Saúde: Editais, 2015b. Disponivel em: $<$ <ttp://www.prefeitura.sp.gov.br/cidade/secretarias/saude/editais/index.php?p=6177 >. Acesso em: 15 de fevereiro de 2016. 
SECRETARIA MUNICIPAL DE SAÚDE DE SÃO PAULO. Prefeitura melhora controle sobre gastos de Organizações Sociais de Saúde. Prefeitura de São Paulo, 04 de maio de 2016 Disponivel em: <http://www.prefeitura.sp.gov.br/cidade/secretarias/saude/noticias/?p=216588>. Acesso em: 26 junho 2016.

SECRETARIA MUNICIPAL DE SAÚdE DE SÃO PAULO. Relatório de acompanhamento orçamentário e financeiro do $3^{\circ}$ quadrimestre de 2015 - Jan a Dez. Prefeitura de São Paulo, 2016. Disponivel em: <http://www.prefeitura.sp.gov.br/cidade/secretarias/upload/saude/Relatorioexecucao orcamentariatrterceiroquadrimestre2015.pdf>. Acesso em: 01 julho 2016.

SEIXAS, Paulo Henrique D.'Ângelo. As organizaçöes sociais de saúde em Säo Paulo, 1998-2002: uma visäo institucional. São Paulo: Tese de Doutorado. Escola de Administraçäo de Empresas de Säo Paulo, 2003.

SILVA GUEDES, Jose da; SANTOS, Rosa Maria Barros dos; LORENZO, Rosicler A Viegas Di. A implantação do Programa de Saúde da Família (PSF) no Estado de São Paulo (1995-2002). Saúde e Sociedade, São Paulo, v. 20, n. 4, p. 875-883, 2011.

SOARES, Laura Tavares Ribeiro. Os custos sociais do ajuste neoliberal no Brasil. In: SOARES, Laura Tavares Ribeiro El ajuste estructural en América Latina. Costos sociales y alternativas. Buenos Aires: CLACSO, Consejo Latinoamericano de Ciencias Sociales, 2001.

SOBRINHO, Eduardo Jorge Martins Alves. Prefácio: Saúde em São Paulo, dificuldades e esperanças. In: SOUSA, Maria Fátima; MENDES, Áquilas Nogueira Tempos radicais da saúde em São Paulo: a construção do SUS na maior cidade brasileira. São Paulo: Hucitec, 2003a. p. 11-5.

SOBRINHO, Eduardo Jorge Martins Alves. São Paulo de volta ao Brasil e à Constituição. In: SOUSA, Maria Fátima; MENDES, Áquilas Nogueira Tempos radicais da saúde em São Paulo: a construção do SUS na maior cidade brasileira. São Paulo: Hucitec, 2003b. p. 25-30. 
SOUSA, Maria Fátima. O PSF na cidade de São Paulo trabalhando em parceria: o compromisso possível. In: SOUSA, Maria Fátima; MENDES, Aquilas Nogueira Tempos radicais da saúde em São Paulo: a construção do SUS na maior cidade brasileira. São Paulo: Hucitec, 2003. p. 91-4.

SOUSA, Maria Fátima; MENDES, Áquilas Nogueira. Tempos radicais da saúde em São Paulo: a construção de SUS na maior cidade brasileira. São Paulo: Hucitec, 2003.

SPTV 1a EDIÇÃO. Prefeitura troca organizações sociais que administram 310 serviços de saúde na capital. Globo Play, São Paulo, 26 de abril de 2016. Disponivel em: <https://globoplay.globo.com/v/4982107/>. Acesso em: 26 de junho de 2016.

STARFIELD, Barbara. Is primary care essential? The Lancet, v. 344 , n. 8930 , p. 1129-33, 1994.

TEIXEIRA, Rodrigo Alves; PINTO, Eduardo Costa. A economia política dos governos FHC, Lula e Dilma: dominância financeira, bloco no poder e desenvolvimento econômico. Economia e Sociedade, Campinas, v. 21, n. Especial, p. 909-41, dez 2012.

TEIXEIRA, Sonia Maria Fleury. O dilema reformista na reforma sanitária brasileira. Revista de Administração Pública, v. 21, n. 4, p. 94-115, 1987.

THE GUARDIAN. François Hollande pushes through labour bill with special decree. The Guardian, 10 de maio de 2016. Disponivel em: $<$ https://www.theguardian.com/world/2016/may/10/francois-hollande-pushes-throughlabour-bill-with-special-decree>. Acesso em: 09 julho 2016.

TRIBUNAL DE CONTAS DO MUNICÍPIO DE SÃO PAULO. O que é O TCMSP? Tribunal de Contas do Município de São Paulo, 2016. Acesso em: 1 julho 2016.

UGALDE, A; HOMEDES, N. Las reformas neoliberales del sector de la salud: déficit gerencial y alienación del recurso humano en América Latina. Revista Panamericana de Salud Pública, v. 17, n. 3, p. 202-9, 2005. 
UNICEF. Cuidados Primários de Saúde - Relatório da Conferência Internacional sobre Cuidados Primários de Saúde Alma-Ata, 1978. Brasília. 1979.

VIANNA, Cid Manso de Mello. Estruturas do sistema de saúde: do complexo médicoindustrial ao médico-financeiro. Physis, v. 12, n. 2, p. 375-90, 2002.

WAHL, Asbjørn. The rise and fall of the welfare state. London: Pluto Press, 2011.

WAITZKIN, Howard. A Marxist view of medical care. Annals of Internal Medicine, v. 89, n. 2, p. 264-78, 1978.

WILLIAMSON, John. A Short History of the Washington Consensus. Law \& Bus. Rev. Am, v. 15, p. 7, 2009.

YÁRNOZ, Carlos. França enfrenta a maior onda de protestos contra a reforma trabalhista. El País, 20 de maio de 2016. Disponivel em: <http://brasil.elpais.com/brasil/2016/05/17/internacional/1463438068_797947.html>. Acesso em: 24 julho 2016.

ZIZEK, Slavoj. Primeiro como tragédia, depois como farsa. 1a. ed. São Paulo: Boitempo, 2011.

ZIZEK, Slavoj. A simples coragem da decisão: um tributo esquerdista a Margaret Thatcher. Blog da Boitempo, 2013. Disponivel em: <https://blogdaboitempo.com.br/2013/04/18/a-simples-coragem-da-decisao-umtributo-esquerdista-a-margaret-thatcher-por-slavoj-zizek/>. Acesso em: 10 julho 2016. 